Portland State University

PDXScholar

1991

\title{
A study of the perceptual learning style preferences of Japanese students
}

Elizabeth Ann Hoffner

Portland State University

Follow this and additional works at: https://pdxscholar.library.pdx.edu/open_access_etds

Part of the Applied Linguistics Commons, and the Bilingual, Multilingual, and Multicultural Education Commons

Let us know how access to this document benefits you.

\section{Recommended Citation}

Hoffner, Elizabeth Ann, "A study of the perceptual learning style preferences of Japanese students" (1991). Dissertations and Theses. Paper 4269.

https://doi.org/10.15760/etd.6153

This Thesis is brought to you for free and open access. It has been accepted for inclusion in Dissertations and Theses by an authorized administrator of PDXScholar. Please contact us if we can make this document more accessible: pdxscholar@pdx.edu. 
AN ABSTRACT OF THE THESIS of Elizabeth Ann Hoffner for the Master of Arts in TESOL presented August 5, 1991.

Title: A Study of the Perceptual Learning Style Preferences of Japanese Students.

APPROVED BY THE MEMBERS OF THE THESIS COMMITTEE:

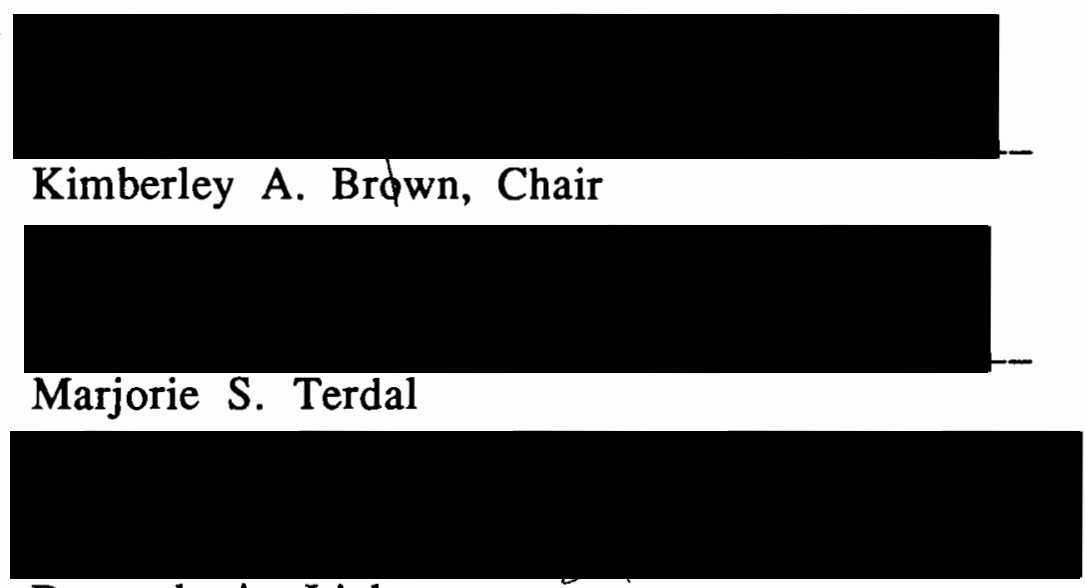

Devorah A. Lieberman

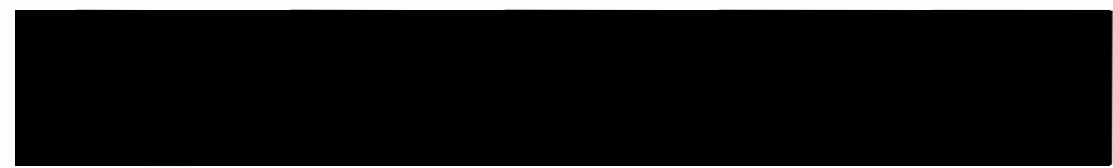

Elaine E. Limbaugh

This study was based on a study by Joy Reid (1987) on the perceptual learning style preferences of English as a Second Language (ESL) students. The purpose of this study was to identify the perceptual learning style preferences of three groups of students: Japanese students studying in the US, Japanese students studying in Japan, and American students studying in the US. The 
perceptual styles studied were visual, auditory, kinesthetic, and tactile, with the additional styles of group and individual learning also being studied. The learning style preferences were identified so as to determine the relationship between style and the variables of native language, length of stay in the US, and major field of study.

The self-reporting learning style questionnaire used in this study was developed by Reid (1987). This instrument was used to determine the learning style preferences of the students, and to identify the preferences as major, minor, and negative styles of learning.

Statistical analysis of the data from the learning style questionnaires indicated that the learning style preferences of most groups were minor preferences; however, when subgroups were established, based on major field and age, some major preferences were found. There were also major preferences identified by individual students, but when individual scores were combined into group scores, minor preference scores emerged. This is contrary to Reid's (1987) study where nearly all of the group learning styles identified were major styles.

The findings in this study are for the most part inconclusive, since many of the research questions were answered as minor learning styles. This means that all the differences found between groups were based on minor preferences for learning. The inconsistency between this study and Reid's (1987) study indicates that further research needs to be done with learning style instruments. It is recommended that researchers seek to further develop the concept of learning style, the identification of its 
elements, and an accurate comprehensive instrument that measures the many elements of learning style. 


\section{A STUDY OF THE PERCEPTUAL LEARNING STYLE PREFERENCES OF JAPANESE STUDENTS}

by

ELIZABETH ANN HOFFNER

A thesis submitted in partial fulfillment of the requirements for the degree of

MASTER OF ARTS

IN

TESOL

Portland State University

1991 


\section{TO THE OFFICE OF GRADUATE STUDIES:}

The members of the committee approve the thesis of Elizabeth Ann Hoffner presented August 5, 1991.

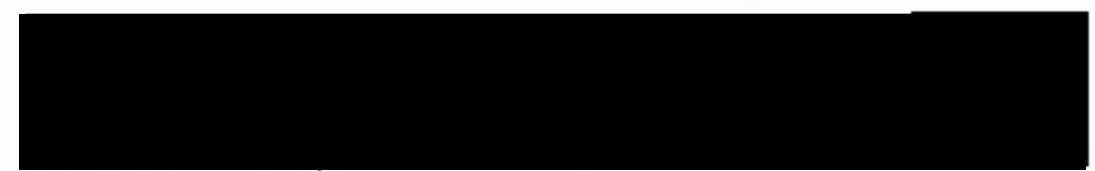

Kimberley A.|Brown, Chair

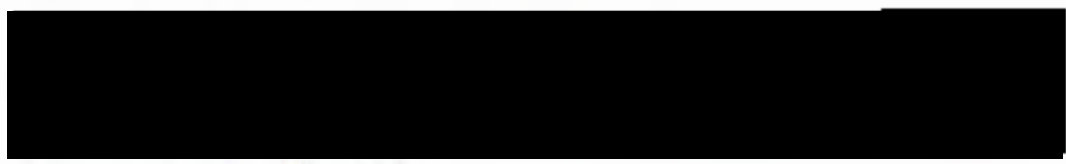

Marjorie S. Terdal

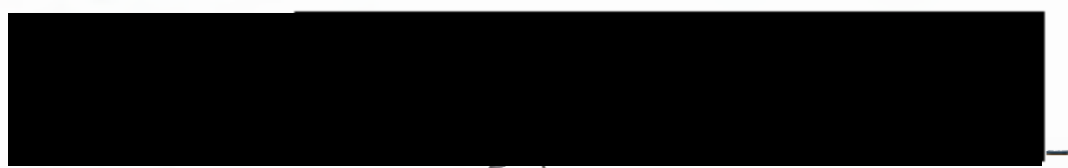

Devorah A. Lieberman

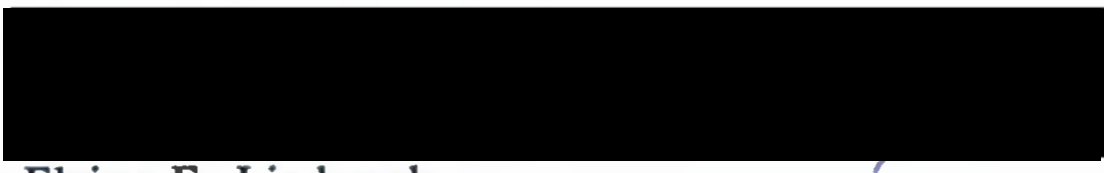

Elaine E. Limbaugh

APPROVED:

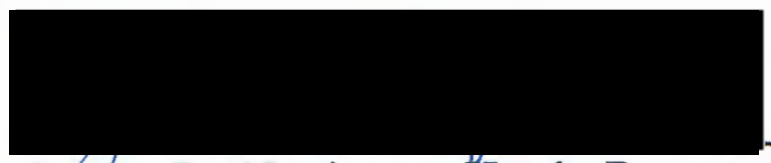

James R. Nattinger, Head, Department of Applied Linguistics

C. William Savery, Vice Provost for Graduate Studies 


\section{ACKNOWLEDGEMENTS}

I would like to take this opportunity to express my appreciation to those people who offered their assistance to me throughout my experience as a graduate student. For their consideration and advice during the completion of this thesis, I am grateful to the members of the thesis committee, including Dr. Kim Brown who served as Chair, Dr. Marge Terdal, Dr. Devorah Lieberman, and Dr. Elaine Limbaugh. Specifically, however, I would like to thank Professor Brown, my research advisor, for her continued confidence and encouragement during the writing of this thesis.

In addition, I would like to thank Dr. James Nattinger, my academic advisor, for his advice and support throughout my graduate studies.

Finally, there are friends and family who helped me in a variety of ways and I would like to thank all of them, too. 


\section{TABLE OF CONTENTS}

\section{PAGE}

ACKNOWLEDGEMENTS.....................................................................................ii

LIST OF TABLES.........................................................................................

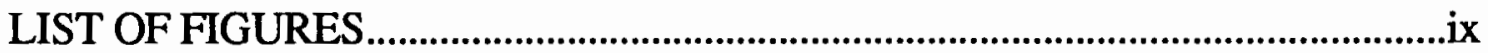

\section{CHAPTER}

I INTRODUCTION

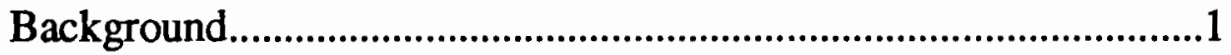

Statement of the Problem....................................................

Research Questions.......................................................................6

I I REVIEW OF LITERATURE................................................................

Learning Styles..........................................................................10

Defining Learning Styles...............................................10

Identification of Learning Styles...............................13

Learning Styles of Native English Speakers...........16

Learning Styles of Second Language Learners.....18

Matching Teaching and Learning Styles.............................20

Conclusion.......................................................................................23

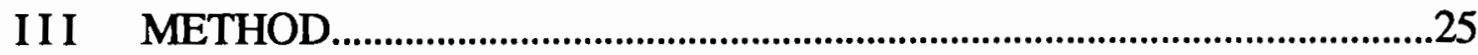

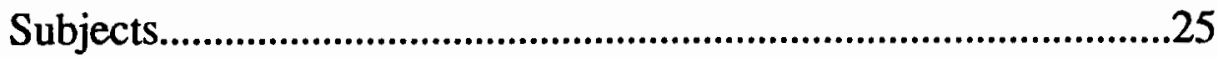

Overview of Subjects........................................................26

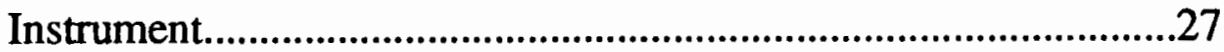

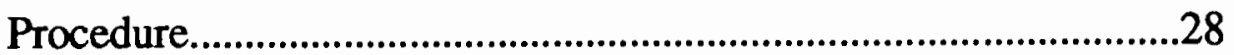




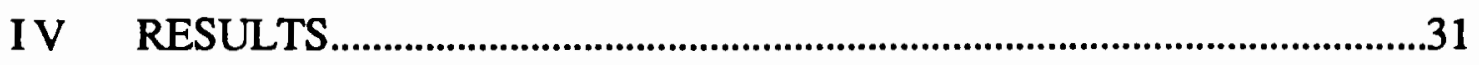

Analysis of Group Styles.......................................................31

Analysis of Differences Among Groups.............................34

Differences in Learning Styles of American

Students and Japanese Students...................34

Differences in Learning Styles of Japanese

Students in the US Less Than 3 months

And More Than 3 Months.

Differences in Learning Styles of American

Students, Japanese Students in the US Less

Than 3 Months and More Than 3 Months..37

Differences in Learning Styles by Major Field of

Study for All Students.

Differences in Learning Styles by Gender for All

Students.

Differences in Learning Styles by Age for All

Students.

Differences in Learning Styles of Japanese

Students in the US by School.

V DISCUSSION.

Summary

Conclusion..

Recommendations.

REFERENCES .64

\section{APPENDICES}

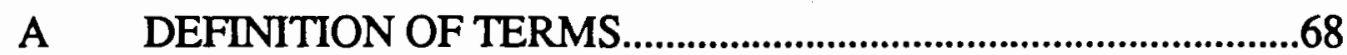

B LEARNING STYLE QUESTIONNAIRE...................................70

C TRANSLATION OF LEARNING STYLE QUESTIONNAIRE75

D BACKTRANSLATION OF LEARNING STYLE

QUESTIONNAIRE.

E RAW DATA 


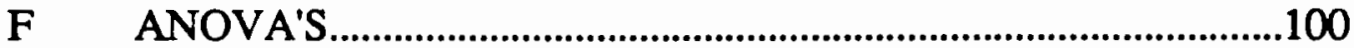




\section{LIST OF TABLES}

TABLE

PAGE

I

Mean Scores for the Preferred Learning Styles of the Japanese in the US, Japanese in Japan, and American Groups

I I

Scheffe Test for the Americans, Japanese in Japan, and Japanese in the US Groups

II I Differences Between Group Mean Scores of American Students and Japanese Students.

IV Scheffe Test for the American Students and Japanese Students.

V

Differences Between Group Mean Scores of Japanese in the US Less Than and More Than 3 Months......37

VI Scheffe test for the Japanese in the US

Less Than and More Than 3 Months

VII Differences Between Group Mean Scores of Americans, Japanese in the US Less Than and More Than 3 Months 38

VIII Scheffe Test for Americans and Japanese in the US Less Than and More Than 3 Months....

IX Differences in Group Mean Scores by Major Field of Study

$\mathrm{X}$

Scheffe Test for Major Fields of Study

XI Group Mean Score Differences for Male and Female Students. 
XII Scheffe Test for Male and Female Students.......................43

XIII Mean Score Differences by Age for All Students...............44

XIV Scheffe Test by Age for All Students................................45

XV Group Mean Score Differences of Japanese in the US by School........................................................46

XVI Scheffe Test by School for Japanese in the US. 


\section{LIST OF FIGURES}

FIGURE

PAGE

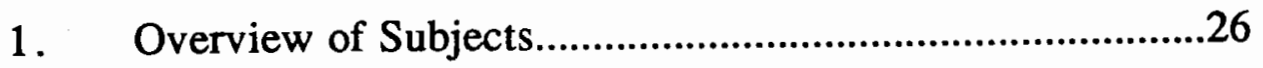




\section{CHAPTER I}

\section{INTRODUCTION}

\section{BACKGROUND}

The concept that individuals differ in their approach to learning has been around since the time of Socrates. Yet, it is only recently that this concept of individual differences in learning has prompted teachers and researchers in education to advocate changes in the classroom. Some changes called for are to make learning style analysis and individualized education major concerns (Carbo, 1984; Dunn \& Dunn, 1978). Also, many researchers support the theory of matching teaching and learning styles, while others advocate stylistic flexibility (Gregorc, 1979; Schmeck, 1981). All of these issues are in response to the studies of differential student approaches to learning. The interest in the differences of the individual learner has been called one of the most promising movements in education (Barbe \& Milone, 1981). Keefe, an advocate of the concept of learning style, has gone so far as to say:

Learning style diagnosis...gives the most powerful leverage yet available to educators to analyze, motivate, and assist students in school...it is the foundation of a truly modern approach to education (1979:132). 
Here, learning style has been defined as "cognitive, affective, and physiological traits that are relatively stable indicators of how learners perceive, interact with, and respond to the learning environment" (Keefe, 1982:4). In this study, I examine the perceptual learning style preferences, as well as the group and individual style preferences, of Japanese students and American students. A preference or preferred learning style refers to an individual's desire for learning in a particular way. Most researchers define a preference as the way a learner prefers to learn, whereas a strength is a skill or measurable ability the student possesses (Carbo, 1984). Perceptual learning style refers to an individual's use of one or more of the senses to understand and remember information and experience (Reid, 1987). Perceptual preferences are usually measured by self-reporting instruments, whereas perceptual strengths are measured by a task of some kind (Barbe \& Milone, 1981 ).

As studied by Dunn (1984) and Reinert (1976) in work with native English speakers, perceptual learning styles are:

1) Visual: reading, studying charts, visualizing objects

2) Auditory: listening to lectures, audiotapes, discussion

3) Kinesthetic: experiential learning, total physical involvement with learning situation, drama, role-play, doing experiments

4) Tactile: "hands on" learning, manipulation of objects

The learning styles of native English speakers or American students, especially perceptual learning styles, have received much attention; however, with the exception of Reid (1987), relatively few 
studies have been done on identifying the learning styles of nonnative English speakers.

Statement of the Problem

With the multicultural variability in English as a Second Language (ESL) classrooms, the study of learning styles of non-native English speakers is a much needed one. Because ESL students sometimes come from profoundly different cultural, linguistic, and educational backgrounds, they may spend much of their time adjusting to their new learning situation (Reid, 1987, p.88). The different customs and attitudes about learning they bring into the classroom may affect how they learn and how they interact. In turn, these differences affect the teacher and complicate the task of effective teaching. The differences in learning style stress the need for further research on the influence of individual and cultural variables, such as educational background, in the learning process.

The first major work of its kind to deal with the learning styles of the non-native student was a study by Joy Reid (1987) titled "The Learning Style Preferences of ESL Students". In her study, Reid identified the perceptual learning style preferences of over 1300 native and non-native English speakers from nine language backgrounds. In addition to identifying the perceptual preferences, Reid also looked at preferences for group and individual learning. This was done because of Reid's interest in these particular styles. The group and individual styles are separate from the four perceptual styles. 
Reid's instrument was a self-reporting questionnaire. With the questionnaire, Reid identified the learning style preferences of the students and looked for relationships between learning style and a number of variables. Native language, length of time studying English in the US, length of time in US, major field, TOEFL score, age, and gender were some of the variables Reid studied.

Some conclusions reached by Reid's study were:

1) The perceptual learning style preferences of non-native English speakers (ESL students) are often significantly different from those of native English speakers.

2) The perceptual learning style preferences of non-native speakers from different language and cultural backgrounds are often significantly different from each other.

3) Analysis of length of stay in the US of ESL students revealed that the longer the stay the more their learning style preferences were like native speakers (for example, they became more auditory the longer they spent in the US)

4) Analysis of major field of study did not reveal significant differences; however, some fields showed significant differences from each other (for example, Engineering and Computer Science majors were more tactile than Humanities majors).

A partial replication of Reid's study was done by Pia in 1989. $\mathrm{He}$ determined the perceptual learning style preferences of Chinese students. The 90 subjects Pia examined were from three groups: Chinese students in the US, Chinese students in China, and American students in the US. For the most part, Pia's results did not support Reid's findings. 
The conclusions from Pia's study were as follows:

1) The perceptual learning style preferences of Chinese students and American students are significantly different. 2) The length of stay in the US did not make a change in the learning style preferences; however, he found that Chinese students in the US less than 18 months had higher mean scores in auditory style than those who had been here for more than 18 months. These results do not corroborate Reid's findings. She found that students who lived in the US longer had a higher preference for auditory learning.

3) The learning style preferences of Chinese students in the US more than 18 months were more similiar to American students than to Chinese students in the US less than 18 months.

4) The learning style preferences of Chinese students studying in the US and Chinese students studying in China were not significantly different.

The conclusions of Reid's and Pia's studies provided the basis for this study. Their work influenced my research questions and objectives. The question now stands as to whether the results of their studies will be replicated here. Can Reid's findings be applied to Japanese students? In Reid's study, the Japanese group did not identify a major group preferred style. She explained this by pointing to the fact that the responses of the Japanese students were more toward the mean (Reid, 1990). This meant that they rarely checked Strongly Agree or Strongly Disagree. Because of this they did not show a major learning style preference. However, they did identify several minor learning styles (tactile, kinesthetic, auditory, 
visual, and individual), and a negative learning style of group learning. This tendency to lean towards the mean is something that $I$ watched for in this study. Also, I reexamined the Japanese group with Reid's questionnaire, according to her guidelines. The question raised is: Will the Japanese students identify a major group learning style, and how similiar will the findings be to Reid's study?

\section{RESEARCH QUESTIONS}

This study, like Pia's, is a partial replication of Reid's 1987 study. The three groups of students surveyed were: Japanese students studying in the US, Japanese students studying in Japan, and American students studying in the US. The purpose of this study was to identify the preferred perceptual learning styles of the three groups and to look for any relationships between the learning styles and the variables of native language, length of time studying English in the US, and major field of study.

The research questions, previously proposed by Reid (1987) and partially replicated by Pia (1989) in work with Chinese students, are restated as follows:

1) Do the perceptual learning style preferences of Japanese students differ from those of American students? If so, how? 2) Do the perceptual learning style preferences of Japanese students change according to length of stay (less than/more than 3 months) in the US? If so, how different are they from those of American students? 
3) Are the perceptual learning style preferences of Japanese students and American students consistent across major fields of study?

Identifying the learning style preferences of Japanese and American students will help teachers to become more sensitive to the wide variability of individual and cultural differences within ESL and multicultural classrooms. The findings of this study may help teachers to better understand the learning style differences that may exist between culture groups. Results may benefit teachers who deal exclusively with learners from this culture group, not as guidelines for strategies to be used with these students, but instead as key points to consider in planning instruction for Japanese learners. For example, if it is found that Japanese students have a strong preference for a particular style, then teachers are recommended to work to expand the styles of these students, instead of attempting to match styles or teach to this style. Training students to expand their stylistic abilities by using strategies will build a stylistic flexibility that prepares them for future educational experiences. Determining student learning styles is the first step to developing stylistic flexibility, because teachers will know what to build upon. Moreover, it is my belief that identifying the learning style preferences of any learner or group of learners will help teachers to meet the learning needs of the students and in the long run lead to more effective teaching. 


\section{CHAPTER II}

\section{REVIEW OF LITERATURE}

\section{INTRODUCTION}

During the past decade, the concept that individuals differ in their approach to learning has gained the attention of numerous researchers (Dunn, 1984; Keefe, 1982; Parry \& Stansfield, 1990; Stevick, 1989). Thirty years ago, emphasis was on cognitive style or how the mind actually processed information (Reid, 1987). Around this time, there was an article by John Carroll (1963) that displaced long-standing beliefs of an individual's place in his/her learning. Carroll proposed that an individual can successfully master any task, given the time necessary to do so. A faith in the abilities of the learner resurfaced and aptitude was reinterpreted by Carroll, not as IQ, but as the time it took to master a task. Research on the individual differences in learning or learning style followed.

Today many educators praise the work of learning style advocates and call the attention being given to learning style one of the most promising movements in contemporary education (Barbe \& Milone, 1981). Through learning style analysis, a new component in the teaching-learning relationship is recognized, a component that redefines the student's place in the teaching process, placing the 
student at the front of his/her learning. With this, educators realize that learning style analysis can be a powerful tool for improving student learning and motivation.

With an understanding of the possibilities that learning style analysis holds for improving learning, there has been a steady increase in research. Much of the research has been concerned with the learning styles of the native English speaker or the American student. Prior to 1980 , relatively few studies looked at the learning styles of the non-native English speaker. However, within the last 510 years, there has been a burgeoning interest in research of the non-native English speaker, or more specifically, the ESL student.

In this chapter, research on the learning styles of native and non-native English speakers is reviewed. The chapter consists of four sections, beginning with an introduction to the concept of learning style. The second section addresses the problem of defining and identifying the elements of learning style, followed by a description of some instruments for measurement. Also in this section are current issues of research on the learning styles of native speakers of English, including learning style diagnosis for reading programs. This leads into research on the learning styles of the second language learner and the potential complications of certain modes of testing in multicultural classes. In the third section, the complicated issue of matching teaching styles and student learning styles is discussed. Finally, the conclusion suggests future directions for learning style research and implications of present research and raises the question: Where do we go from here? 


\section{LEARNING STYLES}

\section{Defining Learning Styles}

Many attempts have been made to define learning style since the term first appeared in the literature. Style, as defined by Fischer and Fischer (1979), is a consistent way a learner processes information, a quality that persists even though the content may change. This is somewhat different from learning strategies which are tasks used by the learner to aid development or learning, such as guessing or memorizing (Oxford, 1990). Style encompasses learning strategies and is the broadest overall term for how an individual learns.

The plethora of definitions shows the number of dimensions involved in learning style and that researchers define the concept by reporting different characteristics. For example, some researchers use the terms "cognitive" and "learning styles" synonymously, although it appears that learning style is the overall style of the learner, encompassing the cognitive and other aspects of learning. One of the most comprehensive conceptions of learning style is that of Keefe. Keefe (1982) defines learning style as "cognitive, affective, and physiological traits that are relatively stable indicators of how learners perceive, interact with and respond to the learning environment" (p.4). The three domains of learning style then are cognitive, affective, and physiological style. Each domain has a number of elements, as noted by Keefe (1982); for example, under cognitive style, which is regarded as the particular way individuals perceive, organize, and retain information, there are the elements of 
perceptual modalities/strengths, field independence/dependence (FI/D), reflectivity vs. impulsivity, tolerance vs. intolerance (Appendix A).

Affective styles deal with the emotions, motivation, and valuing involved in learning. Different elements of affective style are conceptual level or the structure that an individual needs to learn, and locus of control or the degree to which a person believes that events are contingent on their actions and abilities rather than on chance or on other people, whether internal or external forces.

The other domain of learning style is physiological style or the responses that are biologically based, such as time rhythms, which are the differences in readiness of learning based on the time of day. Other elements of physiological style are preferences for a formal or informal environment, lighting, and sound.

Perceptual learning styles, under cognitive style, are what I researched in this study. Perceptual styles refer to the various ways individuals use one or more senses to process or to understand, organize, and remember information or experiences (Reid, 1987). Because perception is the process most often associated with learning, it is one of the most thoroughly investigated of the learning styles, as seen in research by Dunn (1984), Pia (1989), Reid (1987), and Reinert (1976). Perception is intimately linked with learning and teaching, as seen through reading methods such as phonics (auditory) or word recognition (visual).

As mentioned in the first chapter, the four basic perceptual learning channels, identified by Reinert (1976) in research with 
native speakers of English, are:

1) Visual learning: reading, visualizing words/objects

2) Auditory learning: listening to lecture, discussion, tapes

3) Kinesthetic learning: total physical involvement in the learning task

4) Tactile learning: hands-on learning, manipulation of objects/tasks

The four perceptual learning styles are mentioned again so as to make the distinction between a perceptual strength and a perceptual preference. A perceptual/modality strength is the channel that an individual works best from. Strengths are not necessarily fixed characteristics (Gregorc, 1979). They do change with age. This has been noted by developmental research, in that the younger an individual is, the more kinesthetic and tactile he/she is, whereas visual and auditory abilities tend to develop later on (Price, Dunn, \& Sanders, 1980).

A modality preference is the channel that an individual prefers to work out of. Preferences can also be flexible. However, most learners do have strengths or preferences that are fairly stable over time and experience through which they learn most efficiently (Barbe \& Milone, 1981).

Those individuals who have mixed modality strengths or modality integration have a better chance for success in most situations. This is because they will be better able to process information in whatever way it is presented (Barbe \& Milone, 1981). Thus, the ability of some individuals to be more flexible in learning style or style flex (Schmeck, 1981) gives them more opportunities for 
learning in different environments than those individuals who do not have the skills to be flexible.

\section{Identification of Learning Style}

With so many learning style models it is not surprising that a number of instruments have been developed to diagnose particular elements of learning style. Depending upon the focus and goals, it is possible to choose from over 30 tests and inventories (Dunn, DeBello, Brennan, Krimsky, \& Murrain, 1979). Surprisingly, even with the number of instruments, there is no current learning style instrument that can measure all major elements of the three domains of style (cognitive, affective, and physiological) (Keefe, 1982). Many of the instruments are used to measure only a single element or domain and they do so quite well. Some of the instruments measure the cognitive and affective domains, while others the affective and physiological (Keefe, 1982).

An example of an instrument used to identify preferred learning styles is the Edmonds Learning Style Identification Exercise (ELSIE). This instrument, developed by Reinert (1976), is based on the idea that each individual is "programmed" to learn most effectively in some ways and less so in others. The programming of an individual's learning style is based on the internalization of the native language of that individual. Through these hypotheses, ELSIE attempts to identify a particular learning style by using words from the individual's native language and analyzing the response to these words. Analysis of these responses fall into four categories:

1) have a mental image of an object or activity (visual-object) 
2) have a mental image of a word spelled out (visual-word)

3) receive meaning from the sound of the word without any visualization (auditory-verbal)

4) have a fleeting kinesthetic reaction, either emotional

or physical (kinesthetic); (Reinert, 1976:161)

Another popular instrument is called the Learning Style Inventory (LSI). The LSI was developed by Dunn and Dunn (1979) through extensive work with native English speakers. Many elements (affective and physiological) of learning are incorporated in the LSI, from the self-reporting of preferences for sociological elements of group or individual learning to the emotional elements of motivation and persistence. However, the LSI does not include much in the way of the cognitive domain of learning style, only touching upon the area of perceptual modalities (Keefe, 1979).

Other instruments, such as Kolb's (1982) Learning Style Inventory, place emphasis on individual awareness of personal learning style and available alternative modes of learning. Kolb's Learning Style Inventory is based on experiential learning theory (i.e. each individual has a learning style that is a result of hereditary, past experience and demands of the present environment.) The Learning Style Inventory is a self-reporting instrument based on a rank ordering of four possible words in each of nine different sets. Each word represents one of four learning modes: feeling (Concrete Experiential); watching (Reflexive Observation); thinking (Abstract Conceptualization); doing (Abstract Experimentation).

Another instrument that measures more than one learning style domain is the Myers-Briggs Type Indicator (MBTI), developed 
by Myers and Briggs. The MBTI is a measure of basic personality preferences in four dimensions based on Carl Jung's theory of psychological "types" (Keefe, 1982). The MBTI assesses the cognitive and affective dimensions of sensing vs. intuition, thinking vs. feeling, extraversion vs. intraversion, and judging vs. perceiving. Each of the four dimensions is independent of the other three, so that there are 16 possible combinations of preferences called "types" (Parry \& Stansfield, 1990). The theory of MBTI is that the preferences for functioning in certain ways are manifestations of behaviors in daily life.

Most instruments for identifying perceptual learning styles are self-reporting questionnaires, where the learner must report on preferred styles of learning (Reid, 1987). The self-reporting by students identifying strengths/preferences is considered quite reliable. Dunn (1984) writes that most students are able to describe ways they like and dislike to learn, especially when an element is either a strong positive or negative preference.

There are also concerns about strengths and preferences being different. Yet, since most individuals prefer to work out of their strengths, researchers believe that students will not self-report a preference that is not also a strength (Dunn, 1984). However, there is no guarantee that this will be the case. The research on matching teaching styles to student's preferred (self-reported) styles has shown increases in student motivation, greater interest in subject, and higher achievement rates (Cafferty, 1980; Domino, 1979). In 1971, Farr reported that the preferred learning styles identified by students paralleled their actual strengths. This suggests that students 
are able to identify preferred styles and that preferences are indeed typically strengths.

\section{Learning Styles of Native English Speakers}

Most of the instruments for learning style diagnosis were written with native speakers of English in mind. With these instruments, practitioners have sought to identify individual and group learning styles, so as to improve academic achievement, in areas such as reading.

The concern over reading achievement has become a top national priority in the 80 's-90's. In 1979 , the International Reading Association stated that "the differences in learning styles and abilities of children emphasize the need for a variety of approaches to meet those needs" (Carbo, 1984:72). This concern over individual differences in learning style comes at a time when the problem of illiteracy in the US is pervasive. One of the most promising solutions offered to the problem of illiteracy, or increasing reading achievement, is learning style diagnosis. Carbo (1984) recommends that student's learning styles be diagnosed before designing reading programs, followed by teaching students to read through their individual learning style.

The solution of teaching students to read through their individual style raises the question of whether good and poor readers have different styles. Are the good readers good because they have been taught through their perceptual strength? At least three studies reveal that students who have tactile/kinesthetic perceptual strengths, rather than auditory or visual, do not learn as 
well through either phonics or word recognition reading approaches (Carbo, 1980; Urbschat, 1977; Wheeler, 1983). In addition, research by Dunn and Dunn (1978) reports that when students are taught to read through their individual styles, reading achievement and attitude improve significantly.

This leads into the research on perceptual development and the implications it has for reading. In an investigation of nearly 4,000 elementary students, it was determined that the youngest children were the most tactile/kinesthetic and that this was followed by a gradual development of visual strengths and in the later grades followed by the development of auditory strength (Price et al., 1980). Keefe also reported that "perceptual preference seems to evolve for most students from psychomotor (tactile/kinesthetic) to visual/auditory as the learner matures" (1979:127). These findings have been corroborated by other studies (Dunn \& Carbo, 1981). However, others have said that only $15 \%$ of elementary children are kinesthetically oriented (Barbe \& Milone, 1980). Regardless of the numbers, it does seem that a large number of elementary students do not have auditory or visual learning strengths. Yet, American elementary schools rely almost exclusively on auditory or visual modalities and approaches for teaching reading and other skills (Barbe \& Milone, 1981). With the growing body of research on the importance of teaching students to read through their individual learning style, educators are recommended to take a closer look at the idea of teaching students to read in this manner.

Research on secondary and postsecondary native English speakers has also shown interesting trends. Reid (1987) found for 
example, that American students self-reported visual learning as a minor rather than a major preference. This is seen in the wake of claims that mainstream American culture emphasizes visual learning (Bennett, 1979). However, Hodges (1982) claims that $90 \%$ of instruction is geared to the auditory learner. In Reid's study, auditory-kinesthetic was identified as a major learning style. It is important to consider the claim that instruction in the US emphasizes the auditory-visual modalities. If these claims are correct, then many students without perceptual strengths in these learning styles may be at a great disadvantage in the classroom.

\section{Learning Styles of Second Language Learners}

Research in second language learning has primarily been concerned with learning strategies and affective variables involved in learning (Reid, 1987). Learning strategies are tasks used by an individual to improve learning, such as monitoring and using imagery (Brown, 1987; Oxford, 1990) (Appendix A). Affective variables include the emotional elements of learning, such as motivation, responsibility, and persistence. Recently, there has been an increase in research on the learning styles of second language learners. Also, there has been much interest in individual and cultural differences and the difference these differences make in the classroom. This increase in research on second language learning styles is partly due to a concern over how to best meet individual needs in the multicultural and heterogeneous classroom (Reid, 1987). The variability of learning styles may result in frustration of the teachers and students. The different approaches taken by students 
and teachers may cause dissatisfaction with the class and language learning.

General problems arise not only in trying to meet the learning needs of a multicultural classroom, but also in the testing of such a heterogeneous group. A potential problem in testing of multicultural groups is test bias in favor of certain groups. Hansen (1984) claims that the frequently used cloze test for second language learning may contain such bias. The ability to successfully complete the cloze test may be influenced by an individual's cognitive style or how field independent/dependent $(F D / 1)$ a person is. An individual with stronger field independent abilities may be more likely to fill in blanks on a cloze test. This may cause problems in second language testing, because some suggest that FD/I, an element of cognitive style, is a culturally conditioned factor of learning (Gonzales \& Roll, 1985; Ramirez \& Price-Williams, 1974), and that certain groups may be more field independent than others, giving some a possible advantage.

The possibility of such bias, whether individual or cultural in nature should at least cause some second language teachers to reexamine their avenues of testing, so that some styles of learning are not more favored than others. When a teacher chooses cloze testing, there is the likelihood that the ability of field independence is favored. It is important to realize that $\mathrm{FD} / \mathrm{I}$ is only one element of cognitive style, which in turn is only one of three domains of learning style. Thus, choosing a cloze test may lead to unreliable results, in that a teacher may not know if the test is measuring language ability or $\mathrm{FD} / \mathrm{I}$ strengths. The question of whether the cloze test is a reliable 
mode for testing multicultural groups does need to be further investigated. Hansen (1984) makes this clear in his work on cultural bias of cloze testing.

Just as problems with testing may leave some students at a disadvantage, so too may the favored teaching style of a teacher. A study by Farquarson and Stoynoff (1990) addresses the question of teacher and student preferences for instructional practices. The student group consisted of Japanese students studying in ESL programs in the US. The results of their study suggest that Japanese students prefer to learn through lecture and discussion modes and that the least preferred strategies were learner-centered strategies, such as simulation/role-play and peer teaching. The teachers also preferred lecture and discussion modes. Yet, the present emphasis in English language teaching is on learner centered strategies. The results raise the question of whether teachers are aware of current research in language teaching, but do not apply it, or whether teachers are aware of what their students' preferences are.

\section{MATCHING TEACHING AND LEARNING STYLES}

Learning style researchers have explored the notion that since differences do exist between teacher's and student's styles, something should be done to have the two styles mesh. Before this time, the assumption was that if any teacher followed a good method of teaching, all students that could be reached would learn (Fischer \& Fischer, 1979). But with the present understanding that not all 
teaching styles are going to profit all students, educators are addressing the question of what is to be done.

It is no longer only speculation that individual differences exist in classrooms. Now the question has developed into: What are the implications of these individual and even cultural differences in learning and teaching styles? How important are they to the success of the student? What difference do the differences make?

In response, several researchers have advocated matching the group style of the students with a complimentary teaching style (Barbe, Swassing, \& Milone, 1979; Dunn, 1984; Gregorc, 1979). Advocates of this model propose steps for carrying out this matching, which include: 1) examine and diagnose the student's learning style; 2) understand it and classify it; 3) match it with a teaching style of an available teacher, or if one is not available have a teacher adjust his or her style to match student style; and 4) train teachers to do 1 , 2, 3 (Hyman \& Rosoff, 1984).

However, the task of matching teaching and learning styles is criticized by many learning style advocates on several grounds. Some point to the inadequacy of focusing solely on learning style. In the long run it is a disservice to both students and teachers, because it is not correct to say that one element influences teaching more than others (Hyman \& Rosoff, 1984). This is a narrow view of what teaching is about and how it affects students. Teaching is an act that involves many elements - teacher, student, subject matter, learning style, time, environment, motivation, and cultural background, to name only a few. 
In response to the criticism, advocates of matching models often point to the improvement in student motivation and grades, when student and teacher styles are matched. Studies by Cafferty (1980) and Domino (1979) on matching teaching style to student preferred styles have shown increases in academic achievement, as measured by GPA and grades; however, a few studies have contradicted these results (Corbett \& Smith, 1984).

Yet, even with the success rates and increase in motivation seen by matching models, many are skeptical of the process. Some say that the evidence found does not support the claims. Friedman and Alley, (1984) found that the results from such matching treatments have not improved learning and may even be harmful. On the other hand, Doyle and Rutherford (1984) found that the achievement increases were weak, but the effects on motivation were noticeable and commendable.

The research on matching indicates that as of yet there is not enough evidence to guide educators on alignment of teaching style with student learning style (Hyman \& Rosoff, 1984). Thus, arguing that teaching must be modified on the basis of learning style alone is premature. It seems that researchers need to better understand the process of learning style, teaching style, and the many elements involved in the teaching/learning process before any definite statements can be accepted about matching (Dunn et al., 1979). 


\section{CONCLUSION}

At this point in learning style development, there is a widespread lack of agreement. Much information in the learning style paradigm needs to be further analyzed. It often seems that the term learning style has as many definitions as researchers studying it. Researchers report and measure different characteristics of learning style; for example, the Dunns (1978) emphasize stimuli and the elements, Reinert (1976) emphasizes perceptual modes, and Kolb (1982) specifies the environment and past experience. Still others refer to "cognitive style" as "learning style," and some describe "learning strategies" as if they were synonymous with learning style. It is clear that many attempts have been made to define learning style, ranging from definitions to categorizations of learning style elements. Thus, if the concept of learning style is going to be of use to the classroom teacher, learning styles must be understandable, and must not require that the teacher translate the volumes of information into a manageable whole (Davis, Chiasson, \& Schwimmer, 1981).

There are also numerous instruments for measuring learning style. The instruments measure different characteristics and elements of learning style. Presently, there is no single instrument that claims to measure the full range of learning style elements. Therefore, teachers are left to decide what element of learning style they believe is most important to focus on. Some believe that perceptual learning styles, under cognitive style, are the most important. Others prefer to focus on affective elements of motivation 
or physiological elements of the environment. Yet, in order to accurately measure learning style, teachers need to look at the whole, and not only one element in isolation.

Even with the lack of a comprehensive instrument for measuring learning style, many researchers still recommend that teaching and learning styles be matched. These suggestions are premature at this stage of learning style development. There is presently no learning style instrument that measures all domains of learning style (cognitive, affective, and physiological). If teachers choose to match styles, they will have to decide which element is most important for a particular class. Considering the complications of matching styles, it is not prudent for teachers to rush into matching. There needs to be more research on the concept, its many elements, and the measurement of these elements.

Instead of matching, teachers are recommended to encourage the development of learning style flexibility in their students. Several researchers say that those students with stylistic flexibility or style flex are the best learners, in that they can adjust their style or align their needs to fit a given context (Friedman \& Alley, 1984; Schmeck, 1981). Ultimately, these researchers advocate that students be trained to work more efficiently through different styles. 
CHAPTER III

\author{
METHOD
}

\title{
SUBJECTS
}

There were 416 subjects, between the ages of 17 and 46 , participating in this study, 311 of whom were Japanese and 105 of whom were American. Of the Japanese students, 260 were studying in Japan, while 51 were studying in the US. A total of 74 students were females and 329 were males. The subjects were all students in programs of higher education, either in the US or in Japan in the spring term, 1991.

American students were volunteers taken from regular classes, both graduate and undergraduate, while the Japanese students in the U.S. were volunteers from both regular and English as a Second Language (ESL) classes (Beginning to Advanced), all undergraduate. Japanese students in Japan were volunteers from English as a Foreign Language (EFL) classes (Beginning to Advanced) and all students were undergraduate. Most of the subjects who responded were undergraduates (315), with only ten being graduate students.

Subjects were taken from a wide number of classes, such as computer science, humanities, dance, engineering, medicine, and business. Most students did report a major field of study, although nearly all ESL students failed to record a major field, often writing 
ESL instead. Of the reported major fields there were 35 in the Business group, 23 in General Studies and Humanities combined, 12 in Computer Science, 260 in Engineering and Architecture combined, and 31 in Sciences-Medicine combined. Nearly all the Japanese students in Japan were either Engineering or Architecture majors, while the Americans were evenly distributed throughout the fields (see Figure 1 for overview of the subjects involved).

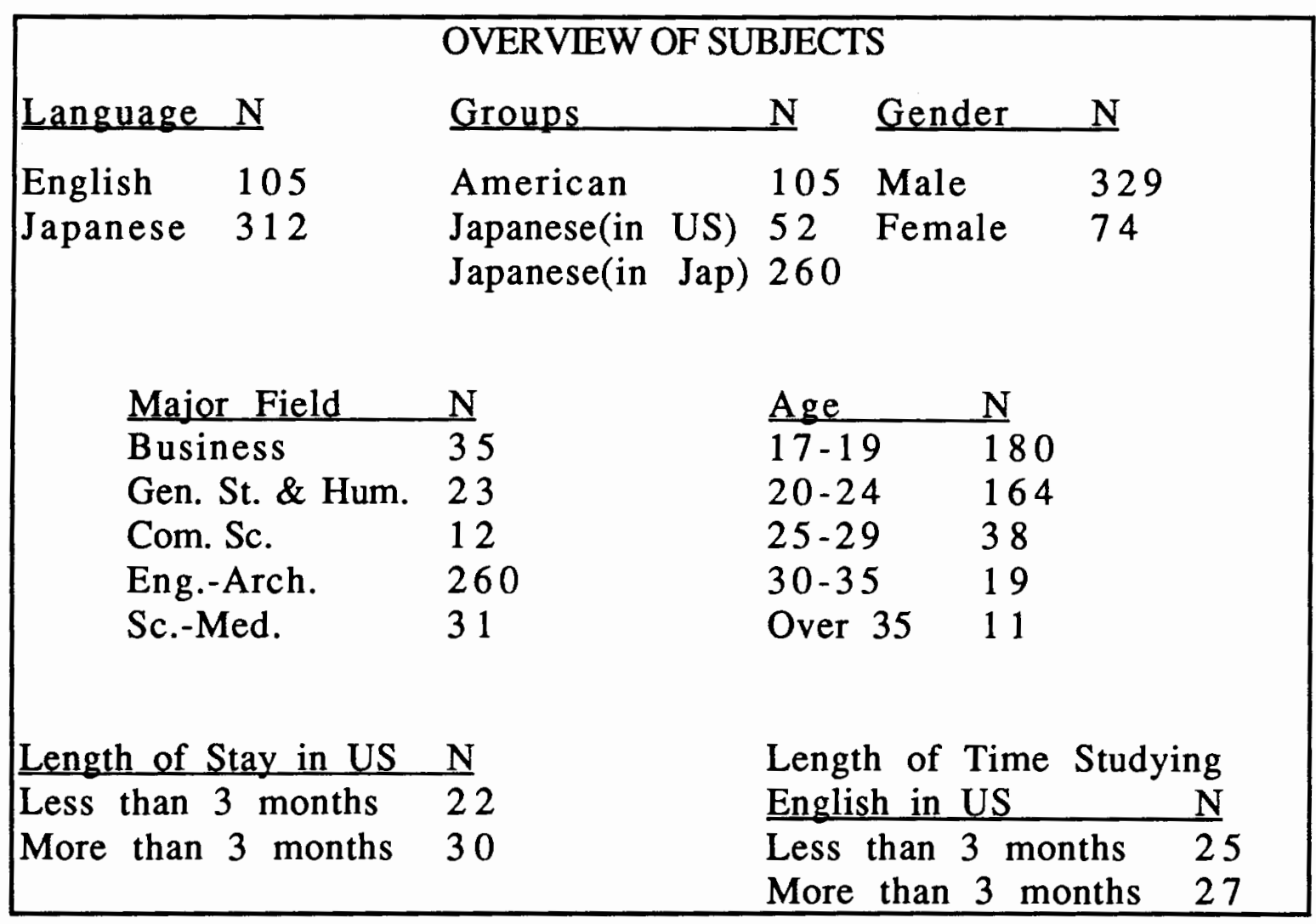

Figure 1. Overview of Subjects. 


\section{INSTRUMENT}

The instrument was a self-reporting questionnaire, developed by Reid (1987) in work with learning style preferences of ESL students (Appendix B). Her questionnaire came about through adaptations of existing learning style questionnaires that dealt with native speakers of English. It consists of 30 statements with five in each of the six learning styles to be looked at (visual, auditory, tactile, kinesthetic, group and individual learning). Students must mark strong or weak preferences for learning on a 5-point Likert scale with sufficient response options: Strongly Agree, Agree, Undecided, Disagree, Strongly Disagree.

The questionnaire was validated by the split-half method which estimates internal-consistency reliability. Correlation analysis of an original set of 60 statements (ten per learning style) determined which five statements would remain in the subset (Reid, 1987).

In keeping with human subject considerations, no personal information was collected that could be used to identify a particular student. Names were not reported. However, information was collected on each student's length of stay in the US, level of English language study, major field, gender, and age.

In order to eliminate English language proficiency as a confounding variable, the questionnaire, instruction sheet, and a cover letter were translated into Japanese by one translator (Appendix C) and backtranslated into English by another translator 
(Appendix D) to ensure the accurate translation of the statements. Both of the translators were native speakers of Japanese.

\section{PROCEDURE}

The translated questionnaire, instruction sheet, and cover letter were mailed to an EFL teacher in Nagoya, Japan. He administered the questionnaire to Japanese students in EFL classes (Beginning to Advanced) at the beginning of the spring term, 1991. All students voluntarily completed the questionnaires in class. These questionnaires were mailed back to me within a month.

Also, at the beginning of the spring term, I contacted ESL teachers at institutions of higher education in the Portland, Oregon area. Almost all of the ESL teachers were hesitant to have me administer the questionnaires in class. So, I gave the questionnaires to the ESL teachers to distribute, explained the questionnaire, my purpose, and let the teachers administer them in the classes to have the students complete them outside of class. By doing this, I knowingly sacrificed a great degree of control and the chances for getting a larger sample size. However, for consistency of administration it seemed necessary to have all the Japanese students complete the questionnaire outside of class, rather than have some students complete them in class and others outside of class. All of the students were asked on a voluntary basis to respond to the questionnaire as it applied to their study of English and to return it the following day. 
For the non-ESL classes, I chose one to two classes in each of the different major fields I was looking at, usually both upper and lower division. I called the different instructors and scheduled times to administer the questionnaire in class. After a brief explanation of the questionnaire and my purpose, I distributed the questionnaires to the students and they completed them in class. Some instructors chose to have me administer the questionnaire at the end of class, others at the beginning. In all classes, the students were given approximately 15 minutes to complete the questionnaire, which was ample time. Questionnaires were collected as students finished.

In some cases students chose not to complete the scoring sheets which tallied the number of responses in each learning style. I completed these scoring sheets and also checked the other scoring sheets for mistakes. The scores determined the major, minor, and negative learning style preferences from the questionnaire, and so accuracy was extremely important.

With the large number of respondents, many of the major fields reported did not fall clearly under any one category. Because of this, I needed to reexamine the original categories and merge them into the following: Business; General Studies and Humanities; Computer Science; Engineering and Architecture; and Sciences and Medicine.

Under General Studies-Humanities were major fields such as psychology, sociology, languages, dance, theatre arts, history, math/economics, social work, english literature, and religious studies. Math/Economics was placed here, instead of under Business, because of the distinction often made between business and economics. 
Applied electronics, Construction, civil-mechanical-electrical engineering, and architecture were placed in the category of Engineering-Architecture. These were combined because of the related nature of the fields. Under Science-Medicine were the major fields of biology, pre-med, pre-vet, physical therapy, health education, pre-dentistry, pharmacy and bio-chemistry. Again, a combination of these was done because of the similiarities of the fields, although the differences are also noted.

The data from the questionnaires were statistically analyzed. Data analyzed included: native language, length of stay in the U.S. ( $<$ or $>3$ months), major field, age, gender, and school. Data collected were then analyzed to compare mean preferences of the group for each learning style. Since the data formed a normal distribution, an analysis of variance (ANOVA) was run on the preference means to see if there were significant differences among groups. The ANOVA was run on the three groups (Japanese in the US, Japanese in Japan, and Americans in the US) and on the subgroups that were established based on native language, length of stay in the US, major field, and others. Then, Scheffé tests were run to see what the specific differences were between the groups. The Scheffé test was chosen because it is the most valid test for unequal sample sizes (Reid, 1987). 


\section{CHAPTER IV}

\section{RESULTS}

The purpose of this chapter is to review the statistical analysis of the raw data from the learning style questionnaires (Appendix E). Presentation of the results consists of two main sections. The first is the analysis of group styles. Here, the preferred learning styles of the three student groups (Japanese in the US, Japanese in Japan, and Americans) are compared. The second section is the analysis of differences among the subgroups. In this section, the relationships between learning style and the variables of native language, length of stay, and major field are presented. Also, since these three variables make up the three research questions for this study, the relevant research question is repeated with each variable. In addition to the above variables, this study analyzed the variables of gender, age, and school. Results from analysis of these variables follow the results from analysis of the three main variables.

\section{ANALYSIS OF GROUP STYLES}

The preferred learning styles of a group were identified by finding a mean score for each of the six learning styles (visual, auditory, kinesthetic, tactile, group, and individual). The mean scores 
were classified as major, minor, and negative learning styles, according to Reid's guidelines. Scores that fell between 38 and 50 were classified as major, between 25 and 37 as minor, and between 0 and 24 as negative.

The mean scores in this study were classified according to these guidelines and nearly all the styles of the various groups fell into the category of minor learning style. When the mean scores of the three student groups were analyzed, no major learning styles were noted, but the American group came close to identifying major styles in kinesthetic (37.41) and tactile learning (37.22) (Table I).

\section{TABLE I}

MEAN SCORES FOR THE PREFERRED LEARNING STYLES OF THE JAPANESE IN THE US, JAPANESE IN JAPAN, AND AMERICAN GROUPS

\begin{tabular}{|c|c|c|c|c|c|c|}
\hline $\begin{array}{l}\text { Student } \\
\text { Group }\end{array}$ & Visual & Auditory & Kines. & Tactile & Group & Indiv. \\
\hline $\begin{array}{l}\text { Jap./Jap. } \\
\mathrm{n}=260\end{array}$ & 29.48 & 34.91 & 35.56 & 36.8 & 33.26 & 27.91 \\
\hline Std Dev. & 5.69 & 4.85 & 5.22 & 5.41 & 7.16 & 6.67 \\
\hline $\begin{array}{l}\text { Jap./US } \\
\mathrm{n}=51\end{array}$ & 30.31 & 34.71 & 34.78 & 34.71 & 31.73 & 31.02 \\
\hline Std Dev. & 5.46 & 4.99 & 6.84 & 6.01 & 7.66 & 7.7 \\
\hline $\begin{array}{l}\text { Amer. } \\
n=105\end{array}$ & 35.52 & 35.78 & 37.41 & 37.22 & 28.32 & 36.68 \\
\hline Std Dev. & 6.5 & 5.71 & 5.86 & 7.08 & 9.13 & 7.74 \\
\hline$P<.05$ & $.0001^{*}$ & .2809 & $.0054^{*}$ & $.038^{*}$ & $.0001 *$ & $.0001^{*}$ \\
\hline
\end{tabular}

*significant

An analysis of variance (ANOVA) was run to test for significant differences in the learning styles among the three groups. Results from the ANOVA indicated significant differences occurring in the 
visual, kinesthetic, tactile, group, and individual styles $(p<.05)$. (For additional information on the ANOVA's see Appendix F).

When the Scheffé test was done as a followup, there were significant differences detected among the three groups in visual, kinesthetic, tactile, group, and individual learning styles (Table II). In visual learning, the Scheffé test results indicated that the Americans had a significantly higher mean score than the Japanese in the US and the Japanese in Japan. The learning style preferences between the Japanese in Japan and the Japanese in the US were not significantly different. In kinesthetic style, Americans again had significantly higher preferences than the Japanese in Japan and the Japanese in the US. There were no significant differences detected between the Japanese groups. For tactile style, Scheffé results indicated that the Americans had significantly higher preferences than the Japanese in the US, but not from the Japanese in Japan. Also noteable is that in tactile style, the difference between Japanese groups approached significance. For group style, both the Japanese in the US and the Japanese in Japan had significantly higher preferences than the Americans. Also, the Americans preferred individual learning significantly more than the Japanese in the US and the Japanese in Japan. The Japanese groups were significantly different from each other, in that the Japanese in the US had a higher preference for individual learning than the Japanese in Japan. 
TABLE II

SCHEFFÉ TEST FOR THE AMERICANS, JAPANESE IN JAPAN AND JAPANESE IN THE US GROUPS

\begin{tabular}{|l|l|l|l|l|l|l|}
\hline $\begin{array}{l}\text { Compari- } \\
\text { son }\end{array}$ & Visual & Auditory & Kines. & Tactile & Group & Indiv. \\
\hline $\begin{array}{l}\text { Amer. vs } \\
\text { Jap (Jap) }\end{array}$ & $13.47^{*}$ & .76 & $3.77^{*}$ & $3.07^{*}$ & $3.29^{*}$ & $10.94^{*}$ \\
\hline $\begin{array}{l}\text { Amer vs } \\
\text { Jap (US) }\end{array}$ & $39.43^{*}$ & 1.1 & 4.07 & .18 & $15.1^{*}$ & $57.3^{*}$ \\
\hline $\begin{array}{l}\text { Jap(Jap) } \\
\text { vsJap(US }\end{array}$ & .42 & .03 & .41 & 2.66 & .83 & $4.11^{*}$ \\
\hline
\end{tabular}

*significant

\section{ANALYSIS OF DIFFERENCES AMONG GROUPS}

To analyze the differences in learning style among groups, the Scheffé test was used. The Scheffé test is a conservative way to do paired comparisons with unequal sample sizes (Reid, 1987). This test determines specifically where the groups were different. The differences were analyzed among the three groups of students and among the subgroups that were established. Subgroups were established based on the variables of native language, length of stay, major field, gender, age, and school. In the presentation of the first three variables, the research question will precede the findings for each particular variable.

Differences in Learning Styles of American Students and Japanese Students

Research Question \#1: Do the perceptual learning style preferences of Japanese students differ from those of American students? If so, how? 
The purpose in analyzing these two groups was to determine whether any significant differences in preferred learning style existed between American students and Japanese students. Results from the ANOVA indicated significant differences between American and Japanese students in the visual, kinesthetic, group, and individual styles $(\mathrm{p}<.05)$. The greatest difference was between the American preference and the Japanese preference for individual learning style. The American students had a mean score of 36.68, while the Japanese students had their lowest mean score here of 28.42 (Table III).

TABLE III

DIFFERENCES BETWEEN GROUP MEAN SCORES OF AMERICAN STUDENTS AND JAPANESE STUDENTS

\begin{tabular}{|l|l|l|l|l|l|l|}
\hline $\begin{array}{l}\text { Sub- } \\
\text { Group }\end{array}$ & Visual & Auditory & Kines. & Tactile & Group & Indiv. \\
\hline $\begin{array}{l}\text { Amer. } \\
\text { n=105 }\end{array}$ & 35.52 & 35.78 & 37.41 & 37.22 & 28.32 & 36.68 \\
Std Dev. & 6.5 & 5.71 & 5.86 & 7.08 & 9.13 & 7.74 \\
\hline $\begin{array}{l}\text { Japanese } \\
\text { n=311 } \\
\text { Std Dev. }\end{array}$ & 29.62 & 34.87 & 35.43 & 36.46 & 33.01 & 28.42 \\
\hline P<.05 & $.0001^{*}$ & 4.87 & 5.51 & 5.56 & 7.26 & 6.94 \\
\hline
\end{tabular}

*significant

Results from the Scheffe test showed significant differences between American students and Japanese students in visual, kinesthetic, group, and individual styles (Table IV). In visual style, the American preference was significantly higher than the Japanese preference. Also, the American preference for kinethetic learning was significantly higher than the Japanese preference. In group 
style, the Japanese had a significantly higher preference than the Americans, while in individual style, the American preference was significantly higher than the Japanese preference.

\section{TABLE IV}

SCHEFFÉ TEST FOR THE AMERICAN STUDENTS AND JAPANESE STUDENTS

\begin{tabular}{|l|l|l|l|l|l|l|}
\hline $\begin{array}{l}\text { Compar- } \\
\text { ison }\end{array}$ & Visual & Auditory & Kines. & Tactile & Group & Indiv. \\
\hline $\begin{array}{l}\text { Amer. vs } \\
\text { Jap. }\end{array}$ & $79.11^{*}$ & 2.49 & $9.76^{*}$ & 1.27 & $28.51^{*}$ & $104.85^{*}$ \\
\hline
\end{tabular}

*significant

Differences in Learning Styles of Japanese Students in the US Less Than 3 Months and More Than 3 Months

Research Question \#2: Do the perceptual learning style preferences of Japanese students change according to length of stay (less than/more than 3 months) in the US? If so, how different are they from those of American students?

These two groups were analyzed to see if there was a change occurring in the learning styles of Japanese students who lived in the US for a longer period of time. There were no significant differences found with the ANOVA or the Scheffé test between these two groups (Table V \& VI). A possible reason for lack of significant differences could be the size of the two groups, with 21 and 30 subjects. Also, there is a possibility that the length of time chosen ( 3 months) may not have been long enough for changes in learning style to occur. Both of these possible explanations are further discussed in the next chapter. 
TABLE V

DIFFERENCES BETWEEN GROUP MEAN SCORES OF JAPANESE IN THE US LESS THAN AND MORE THAN 3 MONTHS

\begin{tabular}{|l|l|l|l|l|l|l|}
\hline $\begin{array}{l}\text { Sub- } \\
\text { Group }\end{array}$ & Visual & Auditory & Kines. & Tactile & Group & Indiv. \\
\hline $\begin{array}{l}<3 \text { mon. } \\
\mathrm{n}=21\end{array}$ & 28.57 & 34.19 & 35.24 & 35.9 & 32.19 & 30.38 \\
Std Dev. & 5.77 & 5.29 & 6.37 & 5 & 7.29 & 8.48 \\
\hline $\begin{array}{l}>3 \text { mon. } \\
\mathrm{n}=30\end{array}$ & 31.53 & 35.07 & 34.47 & 33.87 & 31.4 & 31.47 \\
Std Dev. & 4.97 & 4.83 & 7.23 & 6.58 & 8.02 & 7.22 \\
\hline \begin{tabular}{l} 
P<.05 \\
\hline
\end{tabular} & .0557 & .5428 & .6958 & .2371 & .7209 & .625 \\
\hline
\end{tabular}

TABLE VI

SCHEFFE TEST FOR THE JAPANESE IN THE US LESS THAN AND MORE THAN 3 MONTHS

\begin{tabular}{|l|l|l|l|l|l|l|}
\hline $\begin{array}{l}\text { Compar- } \\
\text { son }\end{array}$ & Visual & Auditory & Kines. & Tactile & Group & Indiv. \\
\hline $\begin{array}{l}<3 \text { mon. v } \\
>3.84\end{array}$ & .38 & .15 & 1.43 & .13 & .24 \\
\hline
\end{tabular}

Differences in Learning Styles of American Students, Japanese Students in the US Less Than 3 Months and More Than 3 Months

Research Question \#2: Do the perceptual learning style preferences of Japanese students change according to length of stay (less than/more than 3 months) in the US? If so, how different are they from those of American students?

The purpose in analyzing these three groups was to determine if Japanese students in the US more than 3 months reported learning styles that were more similiar to American students than to Japanese students who were in the US less than 3 months. The results showed that there was a greater similiarity between the two Japanese groups 
than between the American group and Japanese groups. With the ANOVA, significant differences $(p<.05)$ were found in the visual, kinesthetic, and individual styles between the groups (Table VII).

\section{TABLE VII}

DIFFERENCES AMONG GROUP MEAN SCORES OF AMERICANS, JAPANESE IN THE US LESS THAN AND MORE THAN 3 MONTHS

\begin{tabular}{|l|l|l|l|l|l|l|}
\hline $\begin{array}{l}\text { Sub- } \\
\text { Group }\end{array}$ & Visual & Auditory & Kines. & Tactile & Group & Indiv. \\
\hline $\begin{array}{l}\text { J. <3 mo. } \\
\text { n=21 } \\
\text { Std Dev. }\end{array}$ & 28.57 & 34.19 & 35.24 & 35.9 & 32.19 & 30.38 \\
\hline $\begin{array}{l}\text { J. }>3 \text { mo. } \\
\text { n=30 }\end{array}$ & 31.53 & 5.29 & 6.37 & 5 & 7.29 & 8.48 \\
\hline $\begin{array}{l}\text { Std Dev. } \\
\text { Amer. } \\
\text { n=105 } \\
\text { Std Dev. }\end{array}$ & 4.97 & 6.5 & 34.47 & 33.87 & 31.4 & 31.47 \\
\hline P<.05: & $.0001^{*}$ & .453 & 7.23 & 6.58 & 8.02 & 7.22 \\
\hline
\end{tabular}

*significant

When the Scheffé test was run as a followup to the ANOVA, there were significant differences found in visual and individual styles (Table VIII). Results from the Scheffé showed that in visual style, the Americans had significantly higher preferences than the Japanese in the US less than 3 months and more than 3 months. In individual style, the Americans had significantly higher preferences than the Japanese in the US less than 3 months and more than 3 months. Also noteable is that the Americans had higher mean scores in all learning styles, but group learning. In group learning the Japanese in the US less than 3 months had the highest mean score of all three groups, while they had the lowest mean score in individual 
learning. In individual learning, the Americans on the other hand had the highest mean score of all three groups and they had the lowest mean score in group learning.

\section{TABLE VIII}

SCHEFFÉ TEST FOR AMERICANS, JAPANESE IN THE US LESS THAN AND MORE THAN 3 MONTHS

\begin{tabular}{|l|l|l|l|l|l|l|}
\hline $\begin{array}{l}\text { Compar- } \\
\text { ison }\end{array}$ & Visual & Auditory & Kines. & Tactile & Group & Indiv. \\
\hline $\begin{array}{l}<3 \text { mon. v } \\
>3 \text { mon. }\end{array}$ & 1.43 & .16 & .1 & .56 & .05 & .12 \\
\hline $\begin{array}{l}<3 \text { mon. vo } \\
\text { Amer. }\end{array}$ & $11.2^{*}$ & .73 & 1.07 & .33 & 1.73 & $5.78^{*}$ \\
\hline $\begin{array}{l}>3 \text { mon. v } \\
\text { Amer. }\end{array}$ & $4.92^{*}$ & .2 & 2.62 & 2.88 & 1.46 & $5.28^{*}$ \\
\hline
\end{tabular}

*significant

Differences in Learning Styles by Major Field of Study for All Students

Research Question \#3: Are the perceptual learning style preferences of Japanese and American students consistent across major fields of study?

An analysis of learning styles for major field of study was done to determine if differences existed between the various fields. The major fields of all students (Japanese and American) were grouped into the five categories of: Business; General Studies and Humanities; Computer Science; Engineering and Architecture; and Science and Medicine. The ANOVA indicated significant differences in visual, kinesthetic, tactile, group, and individual styles between major fields $(p<.05)$ (Table IX). Results showed significant differences $(p=.0001)$ in the visual, group, and individual styles between the Business and Engineering-Architecture groups. In the analysis, some major 
learning styles were found for Computer Science in tactile style (39.83), and for General Studies-Humanities in kinesthetic style (39.3) The Engineering-Architecture group was consistently different in style from most of the other major fields; for example, in visual, auditory, kinesthetic, and individual learning, they had the lowest mean scores of all major fields, and in group learning they had the highest mean score. A possible explanation for these differences could be that Japanese students in Japan, over half of all subjects, were in this category. This is discussed more in the next chapter.

\section{TABLE IX}

\section{DIFFERENCES IN GROUP MEAN SCORES BY MAJOR FIELD OF STUDY}

\begin{tabular}{|c|c|c|c|c|c|c|}
\hline $\begin{array}{l}\text { Sub- } \\
\text { Group }\end{array}$ & Visual & Auditory & Kines. & Tactile & Group & Indiv. \\
\hline $\begin{array}{l}\text { Bus. } \\
n=35\end{array}$ & 34.8 & 35.6 & 36.8 & 35.94 & 28 & 35.49 \\
\hline Std Dev. & 6.64 & 5.31 & 5.94 & 6.85 & 10 & 7.78 \\
\hline $\begin{array}{l}\text { Gen. St.- } \\
\text { Hum. } \\
\text { n=23 } \\
\text { Std Dev. }\end{array}$ & $\begin{array}{l}34.78 \\
7.53\end{array}$ & $\begin{array}{l}35.65 \\
5.48\end{array}$ & $\begin{array}{l}39.3 \\
5.93\end{array}$ & $\begin{array}{l}40 \\
6.27\end{array}$ & $\begin{array}{l}30.78 \\
9.06\end{array}$ & $\begin{array}{l}35.22 \\
8.26\end{array}$ \\
\hline $\begin{array}{l}\text { Com. Sc. } \\
\mathrm{n}=12 \\
\text { Std Dev. }\end{array}$ & $\begin{array}{l}34.83 \\
8.63 \\
\end{array}$ & \begin{tabular}{|l|}
35.75 \\
7.01 \\
\end{tabular} & $\begin{array}{l}36 \\
5.78 \\
\end{array}$ & $\begin{array}{l}39.83 \\
3.66 \\
\end{array}$ & $\begin{array}{l}27.5 \\
9.91 \\
\end{array}$ & $\begin{array}{l}37 \\
9.48 \\
\end{array}$ \\
\hline $\begin{array}{l}\text { Eng-Arc } \\
n=260 \\
\text { Std Dev. }\end{array}$ & $\begin{array}{l}29.72 \\
5.88\end{array}$ & $\begin{array}{l}34.92 \\
4.79\end{array}$ & $\begin{array}{l}35.82 \\
5.28\end{array}$ & $\begin{array}{l}36.73 \\
5.6\end{array}$ & $\begin{array}{l}33.2 \\
7.35\end{array}$ & $\begin{array}{l}28.45 \\
7.11\end{array}$ \\
\hline $\begin{array}{l}\text { Sc. }- \text { Med. } \\
n=31 \\
\text { Std Dev. }\end{array}$ & $\begin{array}{l}35.48 \\
6 \\
\end{array}$ & $\begin{array}{l}36.19 \\
6.44 \\
\end{array}$ & $\begin{array}{l}37.16 \\
5.88 \\
\end{array}$ & $\begin{array}{l}37.16 \\
7.23 \\
\end{array}$ & $\begin{array}{l}28.65 \\
8.36 \\
\end{array}$ & $\begin{array}{l}35.71 \\
7.24 \\
\end{array}$ \\
\hline$P<.05$ & $.0001 *$ & .6546 & $.0407^{*}$ & $.035^{*}$ & $.0001^{*}$ & $.0001^{*}$ \\
\hline
\end{tabular}

*significant

The results from the Scheffé test showed significant differences in visual, group, and individual learning (Table $X$ ). In visual style, the 
Business, General Studies-Humanities, Science-Medicine, Computer Science groups, all had significantly higher preferences than the Engineering-Architecture group. In group style, the EngineeringArchitecture group had a significantly higher preference than the Business group. Here, the Engineering-Architecture group had the highest mean score with 33.2, while the Business group had the lowest mean score with 28. In individual style, all groups had significantly higher preferences than the Engineering-Architecture group. The Engineering-Architecture group had their lowest mean score of all the learning styles in individual learning, with 28.45 .

\section{TABLE X}

\section{SCHEFFÉ TEST FOR MAJOR FIELDS \\ OF STUDY}

\begin{tabular}{|l|l|l|l|l|l|l|}
\hline $\begin{array}{l}\text { Compar- } \\
\text { ison }\end{array}$ & Visual & Auditory & Kines. & Tactile & Group & Indiv. \\
\hline $\begin{array}{l}\text { Bus. vs } \\
\text { Eng-Arc }\end{array}$ & $5.2^{*}$ & .13 & .25 & .14 & $3.32^{*}$ & $7.08^{*}$ \\
\hline $\begin{array}{l}\text { Gen.St.vs } \\
\text { Eng-Arc }\end{array}$ & $3.54^{*}$ & .11 & 2.16 & 1.63 & .49 & $4.49^{*}$ \\
\hline $\begin{array}{l}\text { Sc. vs } \\
\text { Eng-Arc }\end{array}$ & $6.02^{*}$ & .43 & .42 & .04 & 2.28 & $6.77^{*}$ \\
\hline $\begin{array}{l}\text { CS vs } \\
\text { Eng-Arc }\end{array}$ & 1.96 & .07 & $3.28 \mathrm{E}-3$ & .8 & 1.48 & $3.89^{*}$ \\
\hline
\end{tabular}

*significant

The above results conclude the analysis of the variables for the research questions. The remainder of this chapter is concerned with the additional variables of gender, age, and school. Analysis of gender and age was done on the combined scores of the three groups. 
The analysis of school was done only for the Japanese students in the US.

Differences in Learning Styles by Gender for all Students

An analysis of learning styles between males and females was done to see if any differences in preferences for learning existed. The ANOVA indicated significant differences in visual, auditory, kinesthetic, group and individual styles $(\mathrm{p}<0.05)$ (Table XI).

\section{TABLE XI}

GROUP MEAN SCORE DIFFERENCES FOR MALE AND FEMALE STUDENTS

\begin{tabular}{|l|l|l|l|l|l|l|}
\hline $\begin{array}{l}\text { Sub }- \\
\text { Group }\end{array}$ & Visual & Auditory & Kines. & Tactile & Group & Indiv. \\
\hline $\begin{array}{l}\text { Male } \\
\text { n=329 } \\
\text { Std Dev. }\end{array}$ & 30.42 & 34.84 & 35.64 & 36.74 & 32.36 & 29.4 \\
\hline $\begin{array}{l}\text { Female } \\
\mathrm{n}=73\end{array}$ & 33.48 & 36.16 & 37.12 & 35.97 & 28.63 & 34.84 \\
Std Dev. & 6.25 & 6.1 & 5.63 & 6.05 & 8.08 & 7.33 \\
\hline \begin{tabular}{l} 
P<.05 \\
\hline
\end{tabular} & $.0002^{*}$ & $.0431^{*}$ & $.0412^{*}$ & .3184 & $.0003^{*}$ & $.0001^{*}$ \\
\hline
\end{tabular}

*significant

Scheffé results indicated significant differences between males and females in visual, kinesthetic, group, and individual styles (Table XII). Females had significantly higher preferences for visual, auditory, kinesthetic, and individual learning than the males. The males preferred group learning significantly more than the females. The greatest difference was between male and female preferences for individual learning, with a female mean score of 29.4 and a male mean score of 34.84 . 
TABLE XII

SCHEFFÉ TEST FOR MALE AND FEMALE STUDENTS

\begin{tabular}{|l|l|l|l|l|l|l|}
\hline $\begin{array}{l}\text { Compar- } \\
\text { ison }\end{array}$ & Visual & Auditory & Kines. & Tactile & Group & Indiv. \\
\hline $\begin{array}{l}\text { Male vs } \\
\text { Female }\end{array}$ & $14.36^{*}$ & $4.12^{*}$ & $4.2^{*}$ & 1 & $13.55^{*}$ & $29.76^{*}$ \\
\hline
\end{tabular}

*significant

Differences in Learning Styles by Age for All Students

An analysis of learning style by age was done to see if any differences existed between younger and older students' preferences for learning. Students were grouped by age as following: Age 17-19; Age 20-24; Age 25-29; Age 30-35; and Age over 35. Results from the ANOVA showed significant differences $(p=.0001)$ in the group, individual, and visual styles (Table XIII). Interesting trends were noted with age, in that the older the student, the higher the mean scores for visual and individual learning, and the younger the student, the lower the mean scores for group learning. Also, the age group "Over 35 " identified a major style in tactile learning (40.18) and came close to identifying a major style in kinesthetic learning (37.45). In the case of the 17-19 age group, their learning styles were found to significantly differ from the learning styles of the other age groups. A possible reason for this could be that most Japanese students studying in Japan fell into this group. This is discussed more in the next chapter. 


\section{MEAN SCORES DIFFERENCES BY AGE FOR ALL STUDENTS}

\begin{tabular}{|c|c|c|c|c|c|c|}
\hline $\begin{array}{l}\text { Sub- } \\
\text { Group }\end{array}$ & Visual & Auditory & Kines. & Tactile & Group & Indiv. \\
\hline $\begin{array}{l}\text { Age } 17-19 \\
\mathrm{n}=180 \\
\text { Std Dev. }\end{array}$ & $\begin{array}{l}29.41 \\
6.19\end{array}$ & $\begin{array}{l}35.09 \\
4.87\end{array}$ & $\begin{array}{l}35.41 \\
5.09\end{array}$ & $\begin{array}{l}35.93 \\
5.47\end{array}$ & $\begin{array}{l}33.11 \\
7.2\end{array}$ & $\begin{array}{l}27.93 \\
7.27\end{array}$ \\
\hline $\begin{array}{l}\text { Age 20-24 } \\
\mathrm{n}=163 \\
\text { Std Dev. }\end{array}$ & $\begin{array}{l}31.58 \\
5.64\end{array}$ & $\begin{array}{l}35.08 \\
4.99\end{array}$ & $\begin{array}{l}36.56 \\
5.96\end{array}$ & $\begin{array}{l}37.31 \\
6.42\end{array}$ & $\begin{array}{l}32.09 \\
7.93\end{array}$ & $\begin{array}{l}31.64 \\
7.67\end{array}$ \\
\hline $\begin{array}{l}\text { Age } 25.29 \\
\mathrm{n}=38 \\
\text { Std Dev. }\end{array}$ & $\begin{array}{l}33.63 \\
7 \\
\end{array}$ & $\begin{array}{l}34.61 \\
5.52 \\
\end{array}$ & $\begin{array}{l}35.68 \\
5.41\end{array}$ & $\begin{array}{l}36.47 \\
5.27\end{array}$ & $\begin{array}{l}29.47 \\
9.87 \\
\end{array}$ & $\begin{array}{l}33.89 \\
8.03 \\
\end{array}$ \\
\hline $\begin{array}{l}\text { Age } 30-35 \\
\mathbf{n}=19 \\
\text { Std Dev. }\end{array}$ & \begin{tabular}{|l|}
34.53 \\
8.69 \\
\end{tabular} & $\begin{array}{l}36.53 \\
7.39 \\
\end{array}$ & $\begin{array}{l}35.26 \\
7.78 \\
\end{array}$ & $\begin{array}{l}36.11 \\
7.26\end{array}$ & $\begin{array}{l}26 \\
8.69 \\
\end{array}$ & $\begin{array}{l}35 \\
8.86 \\
\end{array}$ \\
\hline $\begin{array}{l}\text { Over } 35 \\
n=11 \\
\text { Std Dev. }\end{array}$ & $\begin{array}{l}34.73 \\
6.53\end{array}$ & $\begin{array}{l}35.64 \\
5.05\end{array}$ & $\begin{array}{l}37.45 \\
6.99\end{array}$ & $\begin{array}{l}40.18 \\
4.85\end{array}$ & $\begin{array}{l}25.09 \\
6.59\end{array}$ & $\begin{array}{l}35.82 \\
7.97\end{array}$ \\
\hline$P<.05$ & $.0001 *$ & .7459 & .3244 & .0679 & $.0001^{*}$ & $.0001 *$ \\
\hline
\end{tabular}

\footnotetext{
*significant
}

The results from the Scheffé test, done as a followup, showed significant differences in group, individual, and visual styles (Table XIV). In visual style, the age groups 20-24, 25-29, and 30-35 all had significantly higher preferences than the age group 17-19. In group style, the age group 17-19 had a significantly higher preference than the age groups 30-35, and "Over 35". It is interesting to note in group style, that the age group 17-19 had the highest mean score (33.11), while the age group "Over $35 "$ had the lowest mean score (25.09). In individual style, all age groups had significantly higher preferences than the age group 17-19. The age group 17-19 had the lowest mean score in individual style with 27.93, while the "Over 35" age group had the highest mean score with 35.82 . 
TABLE XIV

\section{SCHEFFÉ TEST BY AGE FOR ALL STUDENTS}

\begin{tabular}{|l|l|l|l|l|l|l|}
\hline $\begin{array}{l}\text { Compar- } \\
\text { ison }\end{array}$ & Visual & Auditory & Kines. & Tactile & Group & Indiv. \\
\hline $\begin{array}{l}\text { Age 17-19 } \\
\text { vs 20-24 }\end{array}$ & $2.62^{*}$ & $6.80 \mathrm{E}-5$ & .88 & 1.17 & .36 & $5.11^{*}$ \\
\hline $\begin{array}{l}\text { Age 17-19 } \\
\text { vs 25-29 }\end{array}$ & $3.63^{*}$ & .07 & .02 & .07 & 1.69 & $4.84^{*}$ \\
\hline $\begin{array}{l}\text { Age 17-19 } \\
\text { vs 30-35 }\end{array}$ & $2.92^{*}$ & .34 & $2.92 \mathrm{E}-3$ & $3.85 \mathrm{E}-3$ & $3.55^{*}$ & $3.72^{*}$ \\
\hline $\begin{array}{l}\text { Age 17-19 } \\
\text { vs over35 }\end{array}$ & 1.91 & .03 & .34 & 1.34 & $2.72^{*}$ & $2.79^{*}$ \\
\hline $\begin{array}{l}\text { Age 20-24 } \\
\text { vs 25-29 }\end{array}$ & .84 & .07 & .19 & .15 & .86 & .68 \\
\hline $\begin{array}{l}\text { Age 20-24 } \\
\text { vs 30-35 }\end{array}$ & .96 & .34 & .22 & .18 & $2.58^{*}$ & .83 \\
\hline $\begin{array}{l}\text { Age 20-24 } \\
\text { vs over35 }\end{array}$ & .66 & .03 & .06 & .6 & 2.06 & .78 \\
\hline $\begin{array}{l}\text { Age 25-29 } \\
\text { vs 30-35 }\end{array}$ & .07 & .09 & .21 & .84 & .67 & .14 \\
\hline $\begin{array}{l}\text { Age 30-35 } \\
\text { vs over35 }\end{array}$ & $1.83 \mathrm{E}-3$ & .05 & .26 & .82 & .02 & .02 \\
\hline
\end{tabular}

*significant

Differences in Learning Styles of Japanese

Students in the US by School

The learning styles of the Japanese students in the US by school were analyzed to see if learning style preferences were shared across schools. The students came from Portland State University (PSU), Western Business College (WBC), the University of Portland (UP), and Concordia College. Results from the ANOVA and Scheffé tests showed no significant differences between the schools (Table XV \& XVI). 
TABLE XV

GROUP MEAN SCORE DIFFERENCES OF

JAPANESE IN THE US BY SCHOOL

\begin{tabular}{|c|c|c|c|c|c|c|}
\hline $\begin{array}{l}\text { Sub- } \\
\text { Group }\end{array}$ & Visual & Auditory & Kines. & Tactile & Group & Indiv \\
\hline $\begin{array}{l}\begin{array}{l}\text { PSU } \\
n=10\end{array}\end{array}$ & 30.6 & 36.6 & 36.2 & 35.2 & 33.2 & 29.2 \\
\hline Std Dev. & 5.25 & 6.54 & 5.2 & 5.27 & 5.59 & 5.27 \\
\hline $\begin{array}{l}\text { WBC } \\
n=7 \\
\text { Std Dev. }\end{array}$ & $\begin{array}{l}27.71 \\
4.82\end{array}$ & $\begin{array}{l}33.14 \\
2.27\end{array}$ & $\begin{array}{l}33.43 \\
6.08\end{array}$ & $\begin{array}{l}34.29 \\
2.43\end{array}$ & $\begin{array}{l}30 \\
7.12\end{array}$ & $\begin{array}{l}32.29 \\
7.43\end{array}$ \\
\hline $\begin{array}{l}\text { UP } \\
\mathrm{n}=11 \\
\text { Std Dev. }\end{array}$ & $\begin{array}{l}29.45 \\
6.99 \\
\end{array}$ & $\begin{array}{l}32.18 \\
5.1 \\
\end{array}$ & $\begin{array}{l}34.36 \\
6.98 \\
\end{array}$ & \begin{tabular}{|l|}
35.09 \\
6.09 \\
\end{tabular} & $\begin{array}{l}30 \\
5.22 \\
\end{array}$ & $\begin{array}{l}1.82 \\
7.97 \\
\end{array}$ \\
\hline $\begin{array}{l}\text { Concordia } \\
n=23 \\
\text { Std Dev. }\end{array}$ & $\begin{array}{l}31.39 \\
4.92\end{array}$ & $\begin{array}{l}35.57 \\
4.43\end{array}$ & $\begin{array}{l}34.78 \\
7.83\end{array}$ & $\begin{array}{l}34.43 \\
7.21\end{array}$ & $\begin{array}{l}32.43 \\
9.51\end{array}$ & $\begin{array}{l}31.04 \\
8.78\end{array}$ \\
\hline $\mathrm{P}<.05$ & .4371 & .1294 & .87 & .9801 & .6992 & .8422 \\
\hline
\end{tabular}

TABLE XVI

SCHEFFÉ TEST BY SCHOOL FOR JAPANESE IN THE US

\begin{tabular}{|l|l|l|l|l|l|l|}
\hline $\begin{array}{l}\text { Compar- } \\
\text { ison }\end{array}$ & Visual & Auditory & Kines. & Tactile & Group & Indiv. \\
\hline $\begin{array}{l}\text { PSU vs } \\
\text { WBC }\end{array}$ & .38 & .7 & .22 & .03 & .23 & .21 \\
\hline $\begin{array}{l}\text { PSU vs } \\
\text { UP }\end{array}$ & .08 & .1 .45 & .12 & $5.43 \mathrm{E}-4$ & .29 & .19 \\
\hline $\begin{array}{l}\text { WBC vs } \\
\text { Conc }\end{array}$ & .81 & .45 & .07 & $104 \mathrm{E}-3$ & .17 & .04 \\
\hline $\begin{array}{l}\text { UP vs } \\
\text { Conc. }\end{array}$ & .31 & 1.21 & .01 & .03 & .24 & .02 \\
\hline
\end{tabular}




\section{CHAPTER V}

\section{DISCUSSION}

This study sought to identify the learning style preferences of three groups: Japanese students studying in the US, Japanese students studying in Japan, and American students studying in the US. The objectives of the study were to determine the relationship between the learning style preferences and a number of different variables, some of which were native language, length of time in the US, and major field. In order to analyze the relationships, subgroups were established. A statistical analysis revealed significant differences between some of the subgroups. An analysis of the differences found are looked at in comparison to Reid's and Pia's studies through a discussion of the research questions. This is followed by a conclusion of the findings for this study and recommendations for further study.

\section{SUMMARY}

According to Reid's (1987) study, ESL students strongly preferred kinesthetic and tactile learning styles. Her results indicated that most groups did not prefer group learning. Also, among the nine language groups Reid surveyed, Japanese students identified no major learning style preferences. The five minor 
preferences of the Japanese students, in order from highest to lowest, were: kinesthetic, tactile, auditory, visual, and individual. Group learning was identified as the least preferred style (i.e. negative style). Also, the Japanese were the least auditory of all the groups, and were significantly less kinesthetic than most of the groups. The subjects from all language backgrounds chose group learning as either a secondary learning style (i.e. minor learning style) or as a negative style. Reid found that the American students had two major preferences of style (i.e. most favored style), with auditory learning highest and kinesthetic learning second. The American students rated individual learning the highest of all the groups. Surprisingly, all of the language groups in Reid's study, except the Japanese, identified at least two major learning style preferences.

In Pia's study, he found that of the three groups surveyed, (Chinese students in China, Chinese students in the US, and American students in the US), none identified major learning styles or negative learning styles. He found that the Chinese students identified only minor learning styles. The Chinese students in China rated kinesthetic, individual, visual, tactile, auditory, and group learning in order from highest to lowest. The Chinese students in the US rated tactile, auditory, visual, kinesthetic, individual, and group learning in order from highest to lowest. No significant differences were detected between these two groups. The American students also identified only minor learning styles in kinesthetic, tactile, individual, visual, auditory, and group learning in order from highest to lowest. In his comparison of the three groups, there was a significant difference in preference for auditory style. 
The three groups in this study were analyzed according to the same guidelines as Reid's and Pia's studies. The learning styles identified were all minor learning styles. There were no major or negative learning styles, just as in Pia's study. However, some major styles were found in the analysis of the subgroups; for example, there were major learning styles found with the age group "Over 35" and with the major field of Computer Science. Both subgroups identified tactile learning as a major style. Also, many individual students did have major learning styles, but when the individual scores were combined into group scores, the wide range of scores converged into minor styles.

The reason for the lack of major learning styles in this study and in Pia's is unknown. Yet, the Japanese students in Reid's study also failed to identify major group styles. There is a possibility that there are faults in the instrument itself. Possible problems with validity and reliability of this instrument were discussed in a recent article by Reid (1990), the author of the instrument. She pointed out the potential pitfalls of using an instrument that is not normed to the population being studied. She explained that in the norming of her survey instrument, there was no existing normed learning styles instrument for ESL students for her to compare measurements with. Reid stressed the importance of a normed instrument for replication to be possible. There have been several attempted replications of Reid's study, as can be seen by Pia (1989) and this study. With Pia's study, the majority of his results did not corroborate with Reid's. So, the lack of major style preferences in this study may be due in part to the possible invalidity of the instrument used. 
Since there were no major learning style preferences for the group mean scores, nearly all of the research questions were answered as minor styles, with the exception of the major field group. This means that all the differences found between groups were based on minor preferences for learning.

Research Question \#1: Do the perceptual learning style preferences of Japanese students differ from those of American students? If so, how?

The answer to the first part of the question is yes. This question is based on Reid's and Pia's studies. Reid found that the learning style preferences of non-native speakers were significantly different from native English speakers. Pia's study also found that the learning style preferences of Chinese students were significantly different from American students, in that the Chinese students were less auditory than the American students. The results of this study support Reid's results, in that the learning style preferences of Japanese students were found to be significantly different from those of American students.

Statistical analysis revealed significant differences between the two groups in the visual, kinesthetic, group, and individual styles. In order from highest to lowest, the Japanese students identified tactile, kinesthetic, auditory, group, visual, and individual learning as minor preferences; whereas the American students identified kinesthetic, tactile, individual, auditory, visual, and group learning as minor preferences. The most noted difference between the two groups was the mean scores for individual learning, in that American students had a much higher preference for individual learning than Japanese 
students. The Americans had a mean score of 36.68 , while the Japanese had a mean score of 28.42. A possible reason for this is cultural. The influence of Japanese culture and the value of the group over the individual may strongly affect attitudes and approaches taken in learning.

It may be that the Japanese students valued group learning because of the emphasis that their culture, their parents, teachers, future employers, place on the role of the individual. This role is to fit into a group and to work for the group. It is also possible that this "group ethic" is strongly emphasized in the schools by the teaching and learning styles Japanese teachers use. The teachers may become models for the students by stressing group over individual work and they may influence the students' choice in styles of learning, in the preference or choice of group over individual learning.

The Americans had mean scores of 36.68 for individual learning and 28.32 for group learning. This is quite a difference. The group mean score was nearly classified as a negative learning style and the individual mean score was nearly a major learning style. Again, it may be likely that culture played a part in the American's preference for individual over group learning. The value of the individual and individualism in the US may determine choices some people make in the ways they prefer to learn. Also, American teachers may encourage students to work alone and to develop independence in learning. This may in turn affect the choices students make in their learning. The students may model what the system, the teachers and schools, value and teach. 
Research Question \#2: Do the perceptual learning style preferences of Japanese students change according to length of stay (more than 3 months) in the US? If so, how different are they from those of Japanese students in Japan?

The answer to the first part of the question is no. This question was also based on Reid's and Pia's studies. Reid found that the longer the non-native students had lived in the US (more than 3 years), the more auditory their preference became. The question raised from her results was whether students adapted their learning styles to the American educational system after they had been in American classes for a longer length of time. However, Pia's results showed that the learning style preferences of Chinese students did not change the longer (18 months) they lived in the US. In Reid's study, she found that students became more auditory the longer they spent in the US; however, Pia found that Chinese students in the US longer became less auditory. In this study no such differences were detected.

Analysis of Japanese students in the US less than 3 months and more than 3 months revealed no significant differences between the two groups. The time of less than/more than 3 months was chosen because of the possible differences that could be detected between sojourners who had just arrived and students who had been in the US for a longer time.

The use of 3 months may have affected the results, in that the length of time chosen may not have been long enough for learning style changes to occur. If changes in learning style or cultural adaptation of learning style takes place it may not occur until after 
the student has spent more time in the country or until the student has became acculturated. The topic of acculturation is a complex one and one that can not be fully addressed here; however, it is quite likely that acculturation takes place over a greater length of time than 3 months. Thus, one possible explanation for the lack of significant differences between groups is that 3 months may not have been long enough a time for learning style changes. Another possible explanation is that the number of subjects in each group was too small. The groups had 21 and 30 subjects. Nonetheless, the size of the groups was large enough to run both statistical tests. With smaller sample sizes the differences would have to be greater in order to be detected.

The choice of 3 months may also account for the differences in results between this study and Reid's and Pia's studies. Since Reid used 3 years and Pia used 18 months, it is difficult to compare results. The findings for the question of whether length of stay in the US affects learning style may not corroborate with Reid's because in this study a shorter time frame was used. This may also explain Pia's lack of similar findings with Reid in that he used a shorter time frame than she did.

Research Question \#3: Are the perceptual learning style preferences of Japanese students and American students consistent across major fields of study?

The answer to this question is no. This question is based upon Reid's study. She did not find a number of differences across major fields; however, she did find that for the six major fields she studied kinesthetic learning was a major learning style preference and group 
learning was a negative learning style preference by all the major fields. Her results showed that Engineering and Computer Science majors were significantly more tactile than Humanities majors. Also, all students identified individual learning as a minor preference.

An analysis of the five major fields in this study, revealed significant differences in the visual, group, and individual styles, between the Business and Engineering-Architecture groups. The Engineering-Architecture group was found to be consistently different from the other major fields. A possible reason for this is that most of the students in the Engineering-Architecture group were Japanese students in Japan from Daido Institute of Technology. The other major field groups did not have the homogeneity that this particular major field group had. Nearly all of the EngineeringArchitecture students were similar in that they were all Japanese students studying in a technical university in Japan. They all had to undergo the same exams in order to enter this institute. All were between the ages of 17 and 24 , and on top of this, nearly all were males. This homogeneous group was markedly different from the other groups. The homogeneity of this group may be the explanation for these differences in learning style. It way be that the similarities in goals, university, and age had an influence on the preference for learning style that they reported on the questionnaire.

The other groups (American and Japanese in Japan) were not so homogeneous. The American students surveyed ranged in age from 17 to 44 , with 42 males and 63 females. They were equally distributed throughout the major fields; however, they all attended the same university. The Japanese students in the US surveyed were 
from four different institutions. They ranged in age from 18 to 28 , with 24 males and 26 females. These students were from a variety of major fields, from Business to English Literature. The subjects in this group were simiar in some ways, but they did not come close to the homogeneity that the Japanese subjects in Japan had.

The bulk of the Engineering-Architecture students came from this homogeneous group of Japanese students. This may account for the differences in learning style preferences between groups, since nearly all differences were between the Engineering-Architecture group and another major field. Native language could be a confounding variable. In order to better understand this possibility, the learning styles of the Engineering-Architecture group should be looked at in comparison to the learning styles of the Japanese in Japan group. The mean scores in all learning styles for both groups varied very little; for example, the Engineering-Architecture group had a mean score in visual learning of 29.72 , while the Japanese in Japan group has 29.48 and in auditory learning, the EngineeringArchitecture group had a mean score of 34.92 , while the Japanese in Japan group had 34.91 .

The reason for making these comparisons in mean scores between these two groups is to further analyze the question of whether native language is a confounding variable. If it is the case that native language has confounded the results, then it is important to look at the above results in light of this and not to make any conclusions based solely on these results. This means that the results of research question \#3 pointing to Engineering-Architecture majors as having distinct learning styles from other major fields must be 
taken as inconclusive, since most of these students came from a similar language and cultural background.

In addition to an analysis of the variables of native language, length of stay, and major field, there was also an analysis run on age, gender, and school. The findings for age indicated that students became increasingly more visual with age. However, all of the significant differences between groups were with the age group 1719. One possibility for this is that a large number of Japanese students studying in Japan were in this age group. If this is the case, then again native language is a confounding variable.

The findings for gender may also be due to native language as a confounding variable. For example, the females preferred individual learning more than the males, while the males had higher preferences in group learning; however, most of the males were Japanese students. Therefore, the analysis of gender differences may be repeating the earlier differences found between American and Japanese students.

It is important to consider the possibility of native language being a confounding variable in some of the subgroups. The reasons for believing this are the results for major field, age and gender. The most noted differences in all of the subgroups occurred with males, age 17-19, in the group Engineering-Architecture. It may be more than a coincidence that the differences were found in the three areas where the number of Japanese students dominated. For example, nearly all of the Engineering-Architecture majors were Japanese students and most of the males were Japanese students between the ages of $17-24$. 
This homogeneous group of Japanese males, age 17-24, studying in similar programs may not be representative of all Japanese students. The large number of subjects in this group who responded comprises over half of the people in this study, and well over half of the Japanese subjects as a whole. This was dealt with statistically by using the Scheffe test which is used with unequal sample sizes. A more interesting issue are the differences found between this homogeneous group of Japanese students and the other groups (Americans and Japanese in the US) which were not so homogeneous.

\section{CONCLUSION}

In this section, the results from this study are evaluated, as are the comparisons made between this study and Reid's and Pia's studies. To begin with, the findings of this study were for the most part quite different from Reid's. Reid found that most language groups identified major learning style preferences, except Japanese. In this study, there was an absence of major group learning styles, even with the American group and most subgroups. This is a serious issue, especially since it was the same instrument used. Pia also failed to identify any major styles in his replication with Chinese and American students. The possible reasons for the lack of major styles in this study have already been discussed. However, the reliability and validity of an instrument is an important concern, and is worth repeating. If there are problems with the reliability of a learning style's instrument, teachers may misdiagnose their students' learning styles. One possible solution, which is further discussed later, is not 
to rely solely on any one instrument. A second instrument, such as the LSI translated into the particular native language, in addition to teacher observations, will reveal if a student's learning style has been accurately identified.

The comparisons made between this study and Reid's and Pia's also showed some interesting trends. For example, a major objective of this study was to determine if the learning styles of Japanese and American students were different. Statistical analysis for this study indicated that, yes, they were quite different. However, further analysis revealed that some of the learning styles of Japanese students in the US were also significantly different from the learning styles of Japanese students in Japan. The two Japanese groups were different from each other and together they were different from American students. Pia's analysis of Chinese students in the US and Chinese students in China showed no differences between the two groups. An interesting note in the difference between the Japanese groups is that the Japanese students in the US had higher preferences for individual learning and lower preferences for group learning than the Japanese students in Japan. This is even more signifcant considering that American students also had high preferences for individual learning and low preferences for group learning. Other research reveals similiar findings of American student preferences for individual over group learning (Vigna \& Martin, 1982). The similiarity in preferences between American and Japanese students in the US could indicate possible cultural adaptation. For example, the mean scores in individual learning of Japanese students in the US were closer to American mean scores 
than to the Japanese in Japan. The mean score in individual learning for Japanese in the US was 31.02, for Americans the mean score was 36.68, while the Japanese in Japan had a 27.91. Could it be that the styles of Japanese students in the US became more like those of Americans in that they preferred individual over group learning. Another interesting trend is with results for group learning among the three groups The mean score in group learning for Japanese in Japan was 33.26, for Japanese in the US it was 31.73 and for Americans it was 28.32. It may be only coincidental that the Japanese in the US had a lower mean score in group learning than the Japanese Japan or it could be the same trend found earlier with individual learning. It could be that the Japanese students who have studied in the US come to value group learning less and individual learning more and in turn become more like the Americans in this style of learning. Yet, these results taken in light of Pia's study, are not conclusive. Additional research could help to identify any changes that occur in the learning style of non-native speakers studying in American classes.

Analysis of length of stay by Japanese students in the US less than 3 months and more than 3 months showed no differences in learning styles between the two groups. These results are surprising when taken with the difference in individual learning styles between Japanese students in the US and Japanese students in Japan. It seems that if there are differences between Japanese students studying in the US and in Japan, there would also be differences between Japanese students in the US less than and more than 3 months. If adaptation occurred with the learning styles of group 
and individual learning, then differences should have occurred between newly arrived Japanese students and Japanese students who have been in the US longer and could have had time for adaptation of learning style to occur. A possible reason there were no differences between the two Japanese groups in the US is the small size of both groups. Sample size for Japanese students in the US was 51 , and when the division of less than/more than 3 months was made, the two groups had 21 and 30 subjects. Another possibility is that 3 months is not long enough a time for learning style changes to occur if they do occur.

When the five major fields were analyzed, there were significant differences found. However, it seems that all of the differences involved the Engineering-Architecture group. Most of the students in this major field group were Japanese males age 1723 from Japan. Because of this, it is difficult to make any implications or to compare these results with Reid's. However, both studies found Computer Science majors significantly more tactile than other groups. In this study, the Computer Science group also identified a major learning style. This is quite interesting when considering the small size of the group, $n=12$. For the most part, research of learning style by major field has revealed few trends, but it may be premature for any definite statement to be made.

\section{Recommendations}

In light of the results from this study and comparisons made with Reid's and Pia's studies, several recommendations for future learning style research are presented. One recommendation is that 
in the assessment of student preferred learning styles, teachers rely not only on one instrument, but instead look to a second instrument and if possible back this up with teacher observations. It is not recommended that teachers use the results of a single learning style instrument to adapt teaching style and class materials; doing so could possibly do more harm than good.

It is also recommended that further research be done with Reid's instrument. This instrument could be used with a second instrument, teacher observations, and student input, in order to compare the results. Also, the instrument could be given to a number of individuals at different points in time. Yet, if learning style was noted to change over a period of time, it might be difficult to determine if there were problems with the instrument or if the individual's learning style simply changed. A further recommendation on the same line is to identify the learning styles of a number of individuals at different times, in order to see if an individual's learning style of today is the same as that of next month or next year. The reason for such a study is to deal with the question of whether learning styles are stable over time. The findings from such a study would be of use to anyone who takes interest in the concept of learning styles.

Another recommendation concerns future research on the learning styles of groups. Group here refers to a collection of individuals. Additional research could address the question of whether it is valid to assess group learning styles or more specifically, group learning styles of cultural groups. In this study, there were two major culture groups: Japanese and Americans. The 
individual student learning styles of the Japanese and the Americans ranged from 10 to 50 . The scores of these individuals were at the extreme, which means they checked Strongly Agree or Strongly Disagree to each statement. This pattern of consistently checking Strongly Agree/Disagree was not common for the Japanese students. In fact, most Japanese students did not check the extremes when they responded to the questionnaire. The few students with extreme scores of 10 or 50 had these scores for only one or two learning styles and not for all the learning styles.

With such a wide range of scores, it could be argued that finding mean scores of group learning styles is not a correct measure. There may be a number of students who have quite different individual styles than the group score. This is a valid concern and one that needs further attention in learning style research.

A number of other recommendations are given by Hyman and Rosoff (1984) to those who plan on using the learning style approach in the classroom. They offer these six recommendations as guidelines:

1) Teachers should see teaching as involving numerous elements, and not focus only on learning style or any one element.

2) Teachers should understand that scores of learning style preferences are not unchangeable or final.

3) Teachers should see learning style as referring to actions of the student rather than abilities, when assessing a student's learning styles. 
4) Teachers should accept a concept of learning style that is broader than cognitive achievement as determined by a numerical score on a test.

5) Teachers should recognize and attend to the only actions they can control - their own - by doing this teachers will come to accept that there are a variety of teaching strategies.

6) Teachers should not use learning style as a unilateral approach - where the teacher assesses the student's learning style and makes a decision, without input from the student. In conclusion, educators are advised to be cautious when using the learning style approach. Any teachers who plan on matching teaching styles and learning styles are advised first to be aware of both sides of the issue - the successes, as well as the failures and criticisms. It is recommended that instead of matching, teachers take a look at training their students to work well in different learning environments, with different learning styles and teaching styles. Developing stylistic flexibility would be more beneficial to students in the long run, than to always attempt matching styles. Also, teachers are asked to follow suit and to work towards flexibility in teaching styles. The results would be of benefit to both teachers and students. 


\section{REFERENCES}

Barbe, W.B., \& Milone, M.N., Jr. (1980). Modality. Instructor, 39(6), 45-47.

Barbe, W.B., \& Milone, M.N., Jr. (1981). What we know about modality strengths. Educational Leadership, 38, 378-380.

Barbe, W.B., Swassing, R.H., \& Milone, M.N., Jr. (1979). Teaching through modality strengths: Concepts and practices. Columbus, OH: Zaner-Bloser.

Bennett, C. (1979). Teaching students as they would be taught: The importance of cultural perspective. Educational Leadership, 36 , 259-268.

Brown, H. D. (1987). Principles of language learning and teaching. New Jersey: Prentice Hall.

Cafferty, E. (1980). An analysis of student performance based upon the degree of match between the educational cognitive style of the teachers and the educational cognitive style of the students. Unpublished doctoral dissertation, University of Nebraska.

Carbo, M. (1980). An analysis of the relationships between modality preferences of kindergarteners and selected reading treatments as they affect the learning of a basic sight-word vocabulary. Unpublished doctoral dissertation, St. John's University.

Carbo, M. (1984). Research in learning style and reading: Implication for instruction. Theory Into Practice, 23, 72-75.

Carroll, J.B. (1963). A model of school learning. Teacher's College Record, 64, 723-733.

Corbett, S., \& Smith, F. (1984). Identifying student learning styles: Proceed with caution. Modern Language Journal, 68, 212-221. 
Davis, D., Chiasson, P., \& Schwimmer. (1981). Style - A manner of thinking. Educational Leadership, 38, 376-378.

Domino, G. (1979). Interactive effects of achievement orientation and teaching style on academic achievement. ACT Research Report, 39, 1-9.

Doyle, W., \& Rutherford, B. (1984). Classroom research on matching learning and teaching styles. Theory Into Practice, 23, 20-24.

Dunn, R. (1984). Learning style: State of the science. Theory Into Practice, 23, 10-19.

Dunn, R., \& Carbo, M. (1981). Modalities: An open letter to Barbe, Milone, and Swassing. Educational Leadership, 38, 381-382.

Dunn, R., DeBello, T., Brennan, P., Krimsky J., \& Murrain, P. (1979). Learning style researchers define differences differently. Educational Leadership, 38, 372-375.

Dunn, R., \& Dunn, K. (1978). Teaching students through their individual learning styles: A practical approach. Reston, VA: Reston Publishing.

Dunn, R., \& Dunn, K. (1979). Learning styles/teaching styles: Should they...can they...be matched? Educational Leadership, 38, 238244.

Farr, B.J. (1971) Individual differences in learning: Predicting one's more effective learning modality. Unpublished doctoral dissertation, Catholic University.

Farquharson, M., \& Stoynoff, S. (1990). Japanese learning preferences: A study of four intensive English programs. ORTESOL Journal, 11, 75-84.

Fischer, B.B., \& Fischer, L. (1979). Styles in teaching and learning. Educational Leadership, 38, 245-254.

Friedman, P., \& Alley, R. (1984). Learning/teaching styles: Applying the principles. Theory Into Practice, 23, 77-81. 
Gonzales, R.R., \& Roll, S. (1985). Relationship between acculturation, cognitive style, and intelligence. Journal of Cross-Cultural Psychology, 16(2), 190-205.

Gregorc, A. (1979). Learning/teaching styles: Potent forces behind them. Educational Leadership, 38, 234-236.

Hansen, L. (1984). Field dependence-independence and language testing: Evidence from six Pacific island cultures. TESOL Quarterly, 18(2), 311-323.

Hodges, H. (1982). Madison prep-alternatives through learning styles. In J.W. Keefe (Ed.), Student learning styles and brain behavior: Programs, instrumentation, research (pp.28-31). Reston, VA: National Association of Secondary School Principals.

Hyman, R., \& Rosoff, B. (1984). Matching learning and teaching styles: The jug and what's in it. Theory Into Practice, 23, 35-42.

Keefe, J. (1979). Learning style: An overview. In J.W. Keefe (Ed.), Student learning styles: Diagnosing and prescribing programs (pp. 1-17). Reston, VA: National Association of Secondary School Principals.

Keefe, J.W. (Ed.). (1982). Student learning styles and brain behavior: Programs, instrumentation, and research. Reston, VA: National Association of Secondary School Principals.

Kolb, D. A. (1982). Learning style inventory technical manual. Boston: McBer \& Co.

Oxford, R. (1990). Language learning strategies: What every teacher should know. New York: Newbury House Publishers.

Parry, T.S., \& Stansfield, C.W. (Eds.) (1990). Language Aptitude Reconsidered. New Jersey: Prentice Hall.

Pia, A. (1989). The perceptual learning styles of Chinese students. Unpublished master's thesis, Portland State University.

Price, G.E., Dunn, R., \& Sanders, W. (1980). Reading achievement and learning style characteristics. The Clearing House, 5, 223-226. 
Ramirez, M., \& Price-Williams, D. (1974). Cognitive style of children of three ethnic groups in the U.S. Journal of Cross-Cultural Psychology, 5(2), 212-219.

Reid, J. (1987). The learning style preferences of ESL students. TESQL Quarterly, 21(1), 87-109.

Reid, J. (1990). The dirty laundry of ESL survey research. TESOL Quarterly, 24(2), 323-338.

Reinert, H. (1976). One picture is worth a thousand words? Not necessarily! Modern Language Journal, 60, 160-168.

Schmeck, R.R. (1981). Improving student learning by improving thinking. Educational Leadership, 38, 384-385.

Stevick, E.W. (1989). Success with foreign languages. New York: Prentice Hall.

Urbschat, K.S. (1977). A study of the preferred learning modes and their relationship to the amount of recall of CVC trigrams, Unpublished doctoral dissertation, University of Michigan.

Vigna, R.A., \& Martin, R.K. (1982). Learning styles at Bishop Carroll High School. In J.W. Keefe (Ed.), Student learning styles and brain behavior: Programs, instrumentation, and research (pp.38-42). Reston, VA: National Association of Secondary School Principals.

Wheeler, R. (1983). An investigation of the degree of academic achievement evidenced when second grade, learning disabled students' perceptual preferences are matched with complementary sensory approaches to beginning reading instruction, Unpublished doctoral dissertation, St. John's University. 
APPENDIX A

\section{DEFINITION OF TERMS}


perceptual/modality style: learner tendency to use the different sensory modes to understand experience (Keefe, 1979)

field independence/dependence: a continuum of analytic to a global way of experiencing the environment; field independent individuals perceive things clearly from the background, but field dependent individuals are influenced by the overall organization of the background (Keefe, 1979)

reflectiveness vs. impulsivity: the consistency in the speed and accuracy of information gathering; reflective individuals are slower, more accurate, while impulsive individuals are faster and less accurate (Keefe, 1979)

tolerance vs. intolerance: the differences in willingness to accept experience that varies from the conventional; low preference implies a preference for more conventional, more predictable ideas and approaches (Keefe, 1979)

imagery: creating a mental image of something in order to aid memory (Oxford, 1990)

monitoring: using conscious knowledge of language to increase accuracy; self-correcting or evaluating one's own language behavior (Brown, 1987) 
APPENDIX B

LEARNING STYLE QUESTIONNAIRE 


\section{PERCEPTUAL LEARNING STYLE PREFERENCE QUESTIONNAIRE}

AGE DATE

NATIVE COUNTRY

GRADUATE STUDENT

What is your major field of study? NATIVE LANGUAGE

How long have you studied English in your country?

How long have you been in the US?

How long have you studied English in the US?

\section{Directions:}

People learn in many different ways. For example, some people learn primarily with their eyes (visual learners) or with their ears (auditory learners); some people prefer 10 learn by experience and/or by "hands-on" tasks (kinesthetic or tactile learners); some people learn better when they work alone while others prefer to learn in groups.

This questionnaire has been designed to help you identify the way(s) you learn besl--the way(s) you prefer to learn.

Read each statement on the following pages. Please respond to the statements AS THEY APPLY TO YOUR MAJOR FIELD OF STUDY.

Decide whether you agree or disagree with each statement. For example, if you sirongly agree, mark:

\begin{tabular}{|c|c|c|c|c|}
\hline $\begin{array}{c}\text { Strongly } \\
\text { Agree }\end{array}$ & Agree & Undecided & Disagree & $\begin{array}{c}\text { Strongly } \\
\text { Disagree }\end{array}$ \\
\hline $\mathrm{X}$ & & & & \\
\hline
\end{tabular}

Please respond to each statement quickly, without too much thought. Try not to change your responses after you choose them. Please answer all the questions. Please use a pen to mark your choices. 
PERCEPTUAL LEARNING STYLE PREFERENCE QUESTIONNAIRE

\begin{tabular}{|c|c|c|c|c|}
\hline $\begin{array}{c}\text { SA } \\
\text { Sirongly } \\
\text { Agree }\end{array}$ & A & $\begin{array}{c}\text { A } \\
\text { Unee }\end{array}$ & $\begin{array}{c}\text { D } \\
\text { Disagree }\end{array}$ & $\begin{array}{c}\text { SD } \\
\text { Strongly } \\
\text { Disagree }\end{array}$ \\
\hline
\end{tabular}

\begin{tabular}{|c|c|c|c|c|c|}
\hline \multirow{2}{*}{\multicolumn{6}{|c|}{$\begin{array}{l}\text { 1. When the teacher tells me the information I } \\
\text { understand better. }\end{array}$}} \\
\hline & & & & & \\
\hline \multicolumn{6}{|l|}{ 2. I prefer to learn by doing something in class } \\
\hline \multirow{2}{*}{\multicolumn{6}{|c|}{$\begin{array}{l}\text { 3. I get more work done when I work with others. } \\
\text { 4. I learn more when I study with a group. }\end{array}$}} \\
\hline & & & & & \\
\hline \multicolumn{6}{|l|}{ 5. In class, I learn more when I study with a group. } \\
\hline \multicolumn{6}{|l|}{$\begin{array}{l}\text { 6. I learn better by reading what the teacher } \\
\text { writes on the chalkboard. }\end{array}$} \\
\hline \multicolumn{6}{|l|}{$\begin{array}{l}\text { 7. When someone tells me how to do something in } \\
\text { class, I learn it better. }\end{array}$} \\
\hline \\
\hline \multicolumn{6}{|l|}{$\begin{array}{l}\text { 9. I remember things I have heard in class better } \\
\text { than things I have read. }\end{array}$} \\
\hline \multicolumn{6}{|l|}{$\begin{array}{l}10 \text {. When I read instructions, I remember them } \\
\text { better. }\end{array}$} \\
\hline \multicolumn{6}{|l|}{$\begin{array}{l}\text { 11. I learn more when I make a model of } \\
\text { something. }\end{array}$} \\
\hline \multicolumn{6}{|l|}{ 12. I understand better when I read instructions. } \\
\hline \multicolumn{6}{|l|}{ 13. When I study alone, I remember things belter. } \\
\hline \multicolumn{6}{|l|}{$\begin{array}{l}\text { 14. I learn more when I make something for a class } \\
\text { project. }\end{array}$} \\
\hline \multicolumn{6}{|l|}{ 15. I enjoy learning in class by doing experiments. } \\
\hline \multirow{3}{*}{\multicolumn{6}{|c|}{$\begin{array}{l}\text { 16. I leam better when I make drawings as I study. } \\
\text { 17. I learn better in class when the teacher gives a } \\
\text { lecture. } \\
\text { 18. When I work alone, I learn better. }\end{array}$}} \\
\hline & & & & & \\
\hline & & & & & \\
\hline \multicolumn{6}{|l|}{$\begin{array}{l}\text { 19. I understand things better in class when I } \\
\text { participate in role-playing. }\end{array}$} \\
\hline \\
\hline \multicolumn{6}{|l|}{$\begin{array}{l}\begin{array}{l}21 . \\
\text { Ihree enjoy working on an assignment with two or } \\
\text { classmates. }\end{array} \\
\end{array}$} \\
\hline \multicolumn{6}{|l|}{$\begin{array}{l}\text { 22. When I build something, I remember what I } \\
\text { have learned better. }\end{array}$} \\
\hline \multicolumn{6}{|l|}{ 23. I prefer to study with others. } \\
\hline \multicolumn{6}{|l|}{$\begin{array}{l}\text { 24. I learn better by reading than by listening to } \\
\text { someone. }\end{array}$} \\
\hline \multicolumn{6}{|l|}{ 25. I enjoy making something for a class project. } \\
\hline \multicolumn{6}{|l|}{$\begin{array}{l}\text { 26. I learn best in class when I can participate in } \\
\text { related activities. }\end{array}$} \\
\hline \multicolumn{6}{|l|}{ 27. In class, I work betler when I work alone. } \\
\hline \multicolumn{6}{|l|}{ 28. I prefer working on projects by myself. } \\
\hline \multicolumn{6}{|l|}{$\begin{array}{l}\text { 29. I learn more by reading textbooks than by } \\
\text { listening to lectures. }\end{array}$} \\
\hline 30. I prefer to work by myself. & & & & & \\
\hline
\end{tabular}




\section{Instructions}

There are 5 questions for each learning style category in this questionnaire. The questions are grouped below according to each learning style. Each question you answer has a numerical value:

\begin{tabular}{|l|l|l|l|l|} 
SA & A & U & D & SD \\
\hline 5 & 4 & 3 & 2 & 1 \\
\hline
\end{tabular}

Fill in the blanks below with the numerical value of each answer. For example, if you answered Strongly Agree (SA) for question 6 (a visual question), write a number 5 (SA) on the blank next to question 6 below.

\section{Visual}

$6=$

When you have completed all the numerical values for Visual, add the numbers. Multiply the answer by 2 , and put the total in the appropriate blank.

Follow this process for each of the leaming style categories. When you are finished, look at the scale at the bottom of the page; it will help you determine your major learning style preference(s), your minor learning style preference(s), and those learning style(s) that are negligible.

VISUAL

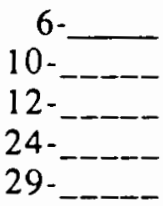

TOTAL $\times 2=$ (Score)

\section{AUDITORY}

1 -

7.

9.

17.

20 -

TOTAL $\times 2=$

\section{KINESTHETIC}

$2-$
$8-$
$15-$
$19-$
$26-$

TOTAL $\times 2=$ (Score)

\section{TACTIE}

11 -

14.

16 -

22 -

25 -

TOTAL $\times 2=$ (Score)

GROUP

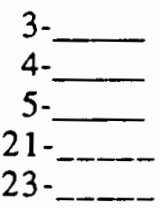

TOTAL x $2=$ (Score)

\section{INDIVIDUAL}

13.

18 .

$27-$

28 -

30 -

TOTAL × $2=$ (Score) 
Dear Student,

This is a study designed to identify the perceptual learning style preferences of American students studying in the U.S. and Japanese students studying in the U.S. and in Japan. You are not obligated to participate. If you do participate, your responses will be completely anonymous. If you do not wish to complete the questionnaire this will not have any effect on your relationship with the school or in any way affect your grade for this course. If you wish to complete the questionnaire then turn to the next page. When you are finished please give the questionnaire to me or to your teacher.

Thank You,

Elizabeth Hoffner 
APPENDIX C

TRANSLATION OF LEARNING STYLE QUESTIONNAIRE 


$$
\text { タイプ別学習スタイルについてのアンケート }
$$

\section{年踰}

出身国

大学院生/大学生 専攻
記入日

母国語

年

月 日

あなたの国では英語をどのぐらい勉強しましたか。

アメリカに来てどのぐらいになりますか。

アメリカでは英語をどのぐらい勉強していますか。

アンケートの答え方

人はそれぞれ巽なった方法で学習します。例之ば、まず規覚や聴賞に訴えて学ぶ人もい るし（視覚・聴賞学習者）、実際に自分でやってみたり、実験によって学ぶ人（筋覚・ 触覚学習者)もいます。ひとりで学ぶ方が学びやすい人もいるし、グループで学ぶかが いいという人もいます。

このアンケートは皆さんが自分に最も適した学習方法、つまり皆さんの好きな学習方法 を知るための手助けをするように考えられたものです。

次のページの文を読んで下さい。各文に対して自分の英語学垍にあてはまるかどうかに よって答えて下さい。

各文が皆さんの学習にどの程度あてはまるか判断して下さい。例えば、「強くそう思う」 場合、以下のように記して下さい。

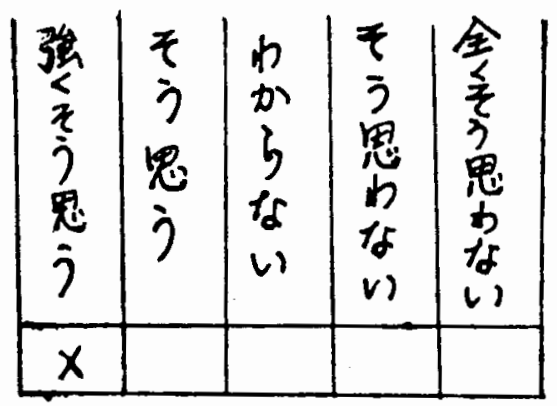

あまり深く考えすぎず、速やかに各文に答えて下さい。一旦選んだ答えは変えないよう にして下さい。全部の質問に答えて下さい。選択を記入するのにはペンを使って下さい。 
77

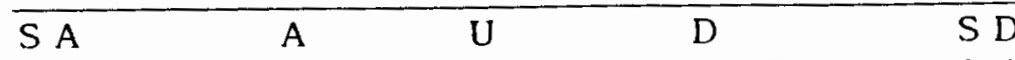

強くそう思うそう思うわからないそう思わない全くそう思わない。

1.先生の説明がある時の方がよく分かる。

2.クラスで学垍する方が好きだ。

3.ほかの人と一緒にする時の方が能率がいい。

4.グルーブで勉強する時の万がよく学べる。

5.クラスでは、ほかの人と一緒に勉強すると

最もよく学べる。

6.先生が黒板に書いたのを読む方がよく学べる。

7、誰かがクラスでやり方を教えてくれる時の ほうがよく学へる。

8.クラスで何か作業する時の方がよく学べる。

9.クラスで聞いたことの方が自分で読んだこと

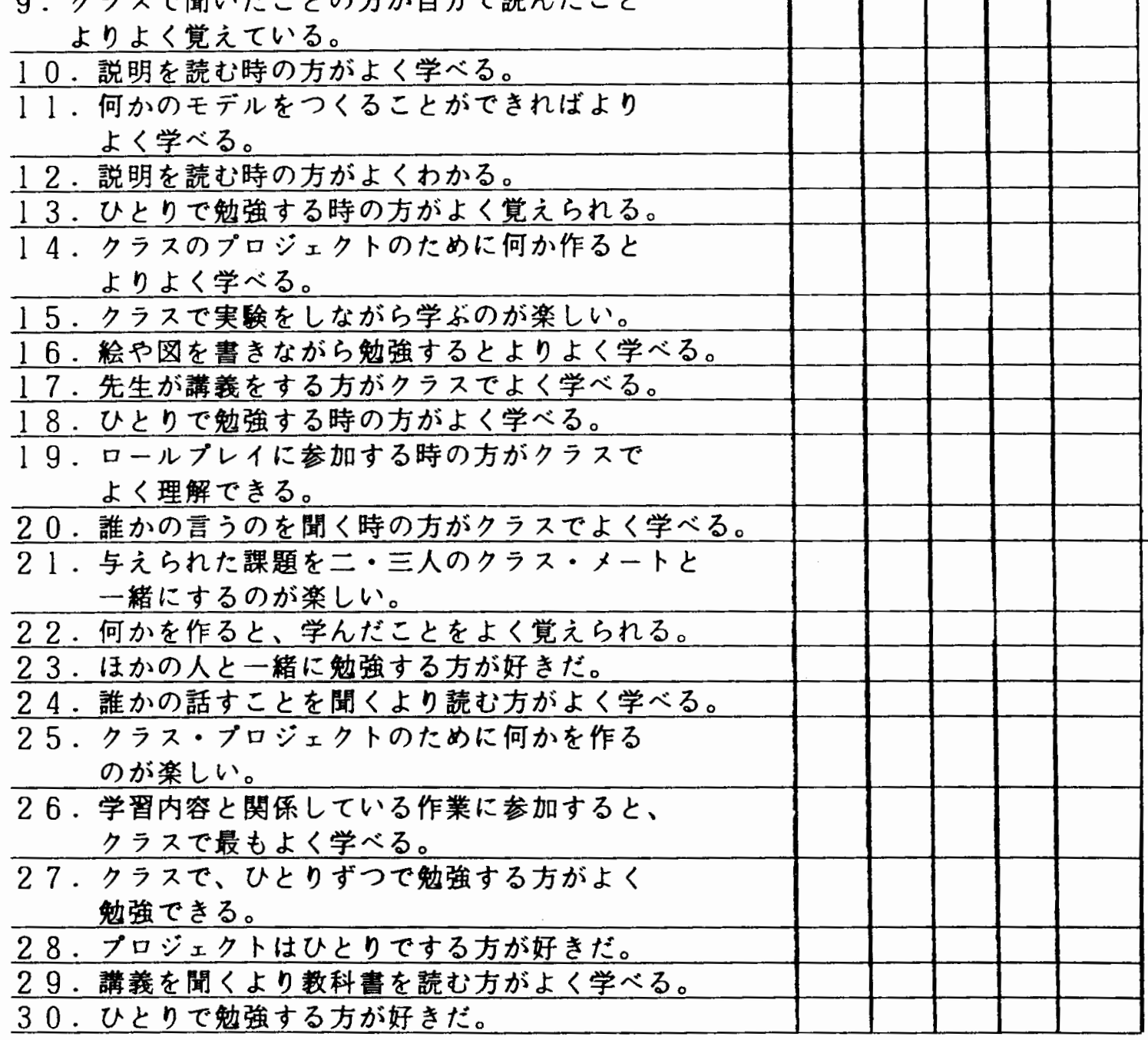


このアンケートには、それぞれの学習スタイルの質問が五つずつあります。質問項目が 学習スタイル別に下記のようにグループ分けされます。各質問に対する皆さんの答えに 以下のような点数が付けられます。

$$
\begin{array}{rrrrr}
\mathrm{S} \mathrm{A} & \mathrm{A} & \mathrm{U} & \mathrm{D} & \mathrm{S} \mathrm{D} \\
5 & 4 & 3 & 2 & 1
\end{array}
$$

下の空榴に、各答えの点数を書き込んで下さい。たとえば、もし質問6（視覚学習に関 する質間）に「強くそう思う」と答えたのなら、質問6の横の空欄に「5」と記入して 下さい。

\section{視覚 \\ $6-5$}

視覚の点数をすべて書き終わったら、たしてください。その答えを2倍して、答えを商 切な空欄に記入して下さい。

このプロセスに従って、各学習スタイルの点数を出して下さい。終わったら、ページの いちばん下のスケールを見て下さい。あなたの主な学習の好み、主ではない学署の好み、 好ましくない学習スタイルがわかります。

わからないことがあったら、先生にきいて下さい。

視賞

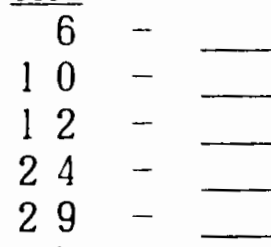

合計

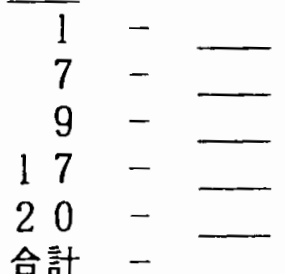

合計 - $\times 2=$

運動感覚

$2-\square-\square$
$8-\square$
$15-\square$
$199-\square$
$26-\square$
合計-

\section{聴賞}

$\times 2=$

(得点)

触覚

11 -

$14-$

$16-$

22

25

合計

$\times 2=$

（得点）

グループ学置

$\begin{array}{cc} & \text { グループ学習 } \\ 3 & \\ 4-- \\ 5-\square \\ 21-\square \\ 23-\square \\ \text { (得点) } \\ 2 \text { 合計 - }\end{array}$

個人学罾

13

$18-\cdots$

$27-$

$28-$

$30-$

合計 - $\times 2=$ （得点）
主な学習スタイルの好み 主ではない学胃スタイルの好み 好ましくない学習スタイル
$38-50$ 点

$25-37$ 点 $0-24$ 点

From Joy Reid, 1987 
学生の皆さんへ。

このアンケートは、アメリカ合案国で勉强しているアメリカ人学生と、日本、そしてア メリカで勉強している日本人学生の学習スタイルの顿向や好みを調へるために作られまし た。アンケートへの参加の義務はありませんが、もし参加して下さるのなら、あななの回 答は完全に繁記名のしのとして扱われます。アンケートに答えたくない場合でも、あなた の大学のクラスや成樍に関して一切の影郎はありませんのでご安心下さい。

では、アンケートに答えて下さる方は次のページに進んで下さい。䊏わりましたら、ク ラスの先生に提出して下さい。よろしくお顆いします。 
APPENDIX D

BACKTRANSLATION OF LEARNING STYLE QUESTIONNAIRE 


\section{Survey of Preferred Learning Styles}

Country Native Language

Graduate/Undergraduate Male/Female

What is your major field of study?

How long have you studied English in your country?

How long have you been in the US?

How long have you studied English in the US?

How to answer the questions:

Everyone learns with a different style. For example, some people learn through their visual senses or through their auditory senses (visual or auditory learner), and others learn by problem solving or experiments (kinesthetic or tactile learner). Or there are some people who prefer to study alone, while others prefer to study in a group.

This survey is designed to help you understand your best learning style, that is your favorite learning style.

Please read the statements on the following page. Answer each question by judging whether it fits your learning style of English.

For each question, make your choice according to how much you feel close to it. For example, if your choice is 1 strongly think so mark:

Try not to think too much, and answer them promptly. Also, try not to change your answers once you have chosen them. Answer all questions. Use a pen to mark your choice.

\section{Survey of Preferred Learning Styles}

1. I understand better when the teacher gives an explanation.

2. I prefer to study in class.

3. It is more efficient when I study with other people.

4. I can learn more when I study in a group.

5. In class, I can learn best when I study with other people.

6. I can leam better by reading the teacher's writing on the board.

7. I can learn better when other people tell me how to do something.

8. I can learn better when I do something in class.

9. I remember what I have heard in class better than what I have read.

10. I can learn better when I read an explanation.

11. I can learn more if I can make a model of something.

12. I can understand better when I read an explanation.

13. I can remember things better when I study by myself.

14. I can learn better if I make something for a class project.

15. I enjoy studying by doing experiments in class.

16. I can learn better by drawing pictures or graphs.

17. I can learn better with the teacher's lecture in class.

18. I can learn better when I study by myself.

19. I can understand better when I participate in role-playing in class. 
20. I can leam better when I listen to someone in class.

21. I enjoy working on a given assignment with a few classmates.

22. I can remember better what I have learned if I try to make something.

23. I prefer to study with other people.

24. I can learn better by reading than by listening to others.

25. I enjoy making something for a class project.

26. I can learn best when I participate in class by working on a project related to class study.

27. I can study better when we study individually in class.

28. I prefer to do a project by myself.

29. I can learn better by reading a textbook than by listening to a lecture.

30. I prefer to study by myself.

Directions:

In this survey there are five questions for each learning style. The questions are divided into the following groups according to each learning style.

The following points are given to the answers you have chosen.

SA 5 A 4 U 3 D 2 SD 1

Please fill in your points in the space below. For example, if you answered "Strongly agree" to question 6 (a visual question), write down "5" in the space next to question 6 below.

Visual

$6=$

When you fill in all the points for the visual part, add up the points. Then double the total, and put the total in the appropriate space.

Following this process please categorize each learning style. When you finish this check the scale at the bottom of this page: you will see your major learning style preference, minor learning style preference, and unfavorable learning style.

\section{VISUAL}

6

10

12

24

29

TOTAL $\times 2=$

\section{AUDITORY}

1

7

9

17

20

TOTAL

\section{KINESTHETIC}

2

8

\section{TACTILE}

11

14

16

22

25

TOTAL $\times 2=$

\section{GROUP}

3

4

5

21

23

TOTAL $\times 2=$ 
TOTAL $\times 2=$ $\times 2=$

Major learning style preference $38-50$

Minor learning style preference 25-37

Negligible

$0-24$

From Joy Reid, 1987 
APPENDIX E

RAW DATA 
Japanese

Students (in U.S)

\begin{tabular}{|c|c|c|c|c|c|c|c|c|c|c|c|c|c|}
\hline Major & Age & $M / F$ & Glund. & in Japan & $\begin{array}{l}\text { Yrs English } \\
\text { in } 45\end{array}$ & $\begin{array}{l}\text { Yrsin } \\
\text { US }\end{array}$ & 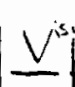 & dit & "y & $\frac{4+z+1}{1+1}$ & Ge & d d & Schoo \\
\hline Business & 23 & $F$ & $u$ & $6 y \times s$ & 2.5 yrs & 2.5 yrs & 28 & 40 & $\overline{38}$ & $34=$ & 343 & 30 & Concordic \\
\hline Socink wrrk & 21 & $F$ & u & & 3 whes & 3uks & 32 & 42 & 46 & 42 & 423 & 36 & $"$ \\
\hline- & 21 & $F$ & u & & $15 \mathrm{mo}$ & 15 m. & 40 & 38 & 32 & 34 & $32: 4$ & 44 & \\
\hline Religisus st. & 24 & $M$ & - & & 9 mo. & $10 \mathrm{mo}$. & 30 & 34 & 48 & 50 & 402 & 22 & \\
\hline Business & 19 & $M$ & - & & $1 y^{r}$ & $\lg r$ & 28 & 36 & 42 & 46 & $24\}$ & 36 & \\
\hline- & 18 & $M$ & - & & 3 wks & 3 inks & 26 & 40 & 40 & 44 & 441 & 14 & \\
\hline - & 25 & $F$ & - & & $6 \mathrm{mo}$. & $6 \mathrm{mo}$ & 28 & 20 & 36 & 34 & 124 & 44 & \\
\hline - & 21 & $M$ & - & & $6 \mathrm{mo}$ & bmo. & 34 & 32 & 34 & 38 & $\equiv 4$ & 30 & \\
\hline- & 19 & $F$ & - & & $9 \mathrm{mo}$ & 9 mo. & $=0$ & 32 & 40 & 28 & 40 & 32 & \\
\hline - & 19 & $F$ & - & 6 mo. & $8 \mathrm{mo}$. & $8 \mathrm{mo}$ & 36 & 38 & 40 & 32 & 30 & 44 & \\
\hline- & 19 & $M$ & U & - & 6 mo. & $6 \mathrm{mo}$ & 34 & 36 & 26 & $24 !$ & 1814 & 40 & \\
\hline Business & 19 & $M$ & - & - & $10 \mathrm{mo}$ & licmo. & 24 & 36 & 28 & 28 & 26 & 26 & \\
\hline Businss Adm. & 20 & $M$ & $u$ & $6 \mathrm{mo}$. & $\operatorname{lyr}$ & $\operatorname{lig} r$ & 42 & 38 & 40 & 44 & 50 & 24 & \\
\hline- & 20 & $M$ & - & & 1.5 yrs. & $1.5 y=$ & 32 & 36 & 40 & $34 !$ & 32 & 32 & \\
\hline- & 20 & $F$ & - & & 3 wks & $3 w k s$ & 32 & 38 & 36 & 34 & 36 & 24 & \\
\hline - & 21 & $F$ & - & & $1.5 y \times s$ & $1.5 \cdot n=$ & 30 & 38 & 34 & 32 & 24 & 44 & \\
\hline - & 23 & $M$ & - & & I mo. & Imo. & 36 & 40 & 14 & 20 & 20 & 40 & \\
\hline- & 23 & - & - & & lyr & lyr & 34 & 36 & 26 & 28 & 40 & 28 & \\
\hline- & 28 & $M$ & - & & 4 days & 4 days & 22 & 34 & 28 & 34 & 46 & 16 & \\
\hline - & 24 & $M$ & - & & $8 \mathrm{mo}$ & $8 \mathrm{mo}$ & 24 & 34 & 38 & 28 & 34 & 26 & \\
\hline - & 29 & $M$ & - & & I mo. & $1 \mathrm{mo}$. & 34 & 32 & 26 & 38 & 34 & 26 & \\
\hline- & 29 & $M$ & - & & $6 \mathrm{mo}$. & $6 \mathrm{mo}$. & 34 & 32 & 40 & 34 & 32 & 30 & \\
\hline- & 35 & $M$ & - & & $2.5 \mathrm{mo}$ & $2.5 \mathrm{mo}$ & 32 & 36 & 28 & 32 & 22 & 26 & \\
\hline - & & $F$ & u & $7 y$ & 7 mo. & 7 mo & 32 & 36 & 32 & 24 & 34 & 28 & PSU \\
\hline- & 22 & $F$ & $u$ & & $1 \mathrm{mo}$. & $\operatorname{lm} 0$. & 28 & 46 & 38 & 36 & 32 & 26 & 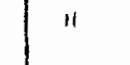 \\
\hline Englsh liter & 29 & $F$ & - & 10 yes & $8 \mathrm{mo}$ & $8 \mathrm{mo}$ & 30 & 36 & 28 & 34 & 30 & 24 & \\
\hline Pusiness & 20 & $M$ & - & & $6 m_{0}$ & $6 \mathrm{mo}$ & 20 & 36 & 40 & 38 & 38 & 26 & \\
\hline Ecoromics & 21 & $M$ & $u$ & 8.5 yrs & 2 wks & 2 wks & 38 & 36 & 38 & 40 & 34 & 34 & \\
\hline- & 27 & $M$ & - & & $1 y x$ & $2 y \times s$. & $3 t$ & 46 & 42 & 42 & $-46 \mid$ & 22 & \\
\hline Giri Emn... & 23 & $M$ & u & 8 yrs & $\equiv r r \mathrm{~J}$ & $3 \mathrm{rog}$ & 28 & 30 & 32 & 32 & 26 & 36 & \\
\hline- & 20 & $F$ & - & $8 \mathrm{grs}$ & 2wiks & zuits & $\equiv$ & 132 & 40 & 34 & $3 x$ & 34 & \\
\hline
\end{tabular}




\section{Japanese}

\section{Students (in US)}

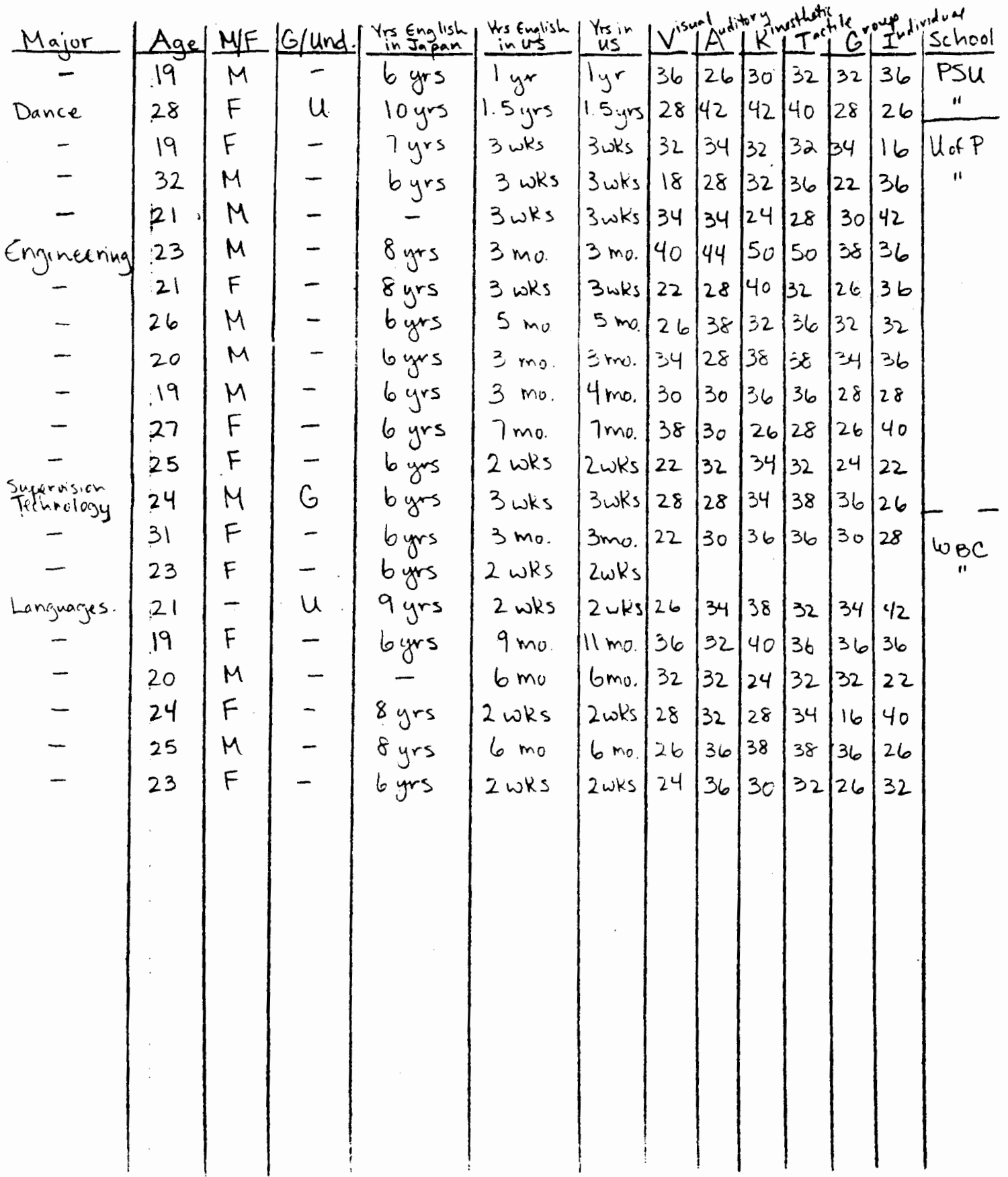




\section{American}

Students

\begin{tabular}{|c|c|c|c|c|c|c|c|c|c|c|}
\hline Majer & Age & $M / F$ & Glund. & $V$ & $A^{u}$ & 1 & & $G^{r}$ & $I^{n}$ & School \\
\hline Businiss & 31 & $F$ & U & 34 & 32 & 28 & 36 & 32 & 34 & PSU \\
\hline$" 1$ & 22 & $M$ & $u$ & 32 & 34 & 34 & 32 & 16 & 46 & " \\
\hline & 21 & $F$ & $u$ & 42 & 46 & $3 t$ & 26 & 32 & 40 & \\
\hline & 3 & $F$ & $u$ & 42 & 34 & 44 & 40 & $=2$ & 128 & \\
\hline$"$ & 38 & $F$ & $G$ & 36 & 36 & 40 & 44 & 20 & 40 & \\
\hline. & 27 & - & $u$ & 48 & 34 & 40 & 36 & 46 & 30 & \\
\hline . & 29 & $F$ & $u$ & 44 & 34 & 42 & 40 & 38 & 24 & \\
\hline . & 23 & $M$ & u & 40 & 34 & 40 & 44 & 26 & 50 & \\
\hline & 23 & $F$ & $u$ & 34 & 42 & 36 & 46 & 20 & 46 & \\
\hline & 28 & $F$ & $u$ & 32 & 32 & 36 & 40 & 26 & 34 & \\
\hline & 29 & $M$ & $u$ & 38 & 28 & 38 & 40 & 24 & 40 & \\
\hline & 27 & $F$ & $u$ & 38 & 34 & 34 & 34 & 12 & 40 & \\
\hline & 34 & $M$ & $u$ & 36 & 28 & 34 & 32 & 42 & 20 & \\
\hline & 26 & $F$ & $u$ & 32 & 34 & 28 & 30 & 20 & 38 & \\
\hline & 22 & $H$ & u & 30 & 30 & 36 & $3 t$ & 32 & $3 \dot{x}$ & \\
\hline & 25 & $M$ & $u$ & 28 & 40 & 44 & 30 & 32 & 36 & \\
\hline & $i 2$ & $M$ & $u$ & 28 & 44 & 44 & 34 & 28 & 30 & \\
\hline & 21 & $F$ & $u$ & 30 & 30 & 36 & 40 & 38 & 30 & \\
\hline$\because$ & 27 & $M$ & $G$ & 42 & 38 & 40. & 38 & 14 & 46 & \\
\hline .. & 3 & $f$ & $u$ & 40 & 48 & 20 & 32 & 12 & 36 & \\
\hline .. & 44 & $F$ & U & 32 & 36 & 44 & 36 & 22 & 34 & \\
\hline. & 29 & $M$ & $u$ & 34 & 40 & 30 & 28 & 34 & 32 & \\
\hline & 22 & $M$ & $u$ & 24 & 30 & 32 & 18 & 10 & 50 & \\
\hline ". & 3 & $F$ & $u$ & 42 & 36 & 30 & 30 & 24 & 34 & \\
\hline . & 26 & $M$ & $u$ & 40 & 34 & 32 & 34 & 14 & 48 & \\
\hline 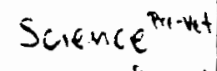 & 26 & $F$ & - & 34 & 36 & 38 & 36 & 30 & 32 & \\
\hline " hy and & 26 & $M$ & $u$ & 42 & 36 & 34 & 34 & 16 & 46 & \\
\hline " & 21 & $F$ & $u$ & 30 & 38 & 44 & 36 & 36 & 28 & \\
\hline Errynter & 19 & M & u & 34 & 38 & 42 & 40 & 34 & 28 & \\
\hline Science & 35 & $F$ & - & 32 & 50 & 32 & 22 & 26 & 32 & \\
\hline Pre.mers & 2.6 & $M$ & u & 30 & 40 & 28 & 24 & 22 & $=26$ & \\
\hline
\end{tabular}


AMERICAN

Students

\begin{tabular}{|c|c|c|c|c|c|c|c|c|c|c|}
\hline Majer & Age & $M / F$ & Glund. & 7 & $A$ & 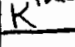 & $i$ & 6 & $I$ & chool \\
\hline scikuke frod. & 24 & $F$ & - & 34 & 28 & 44 & 44 & 30 & 34 & PSU \\
\hline " Biotogy & 22 & $F$ & U & 34 & 38 & $\equiv 2$ & 38 & 28 & 30 & " \\
\hline Psychology & 24 & $F$ & $u$ & 32 & 42 & 36 & 42 & 28 & 38 & \\
\hline Science Biofom. & 21 & $M$ & $u$ & 38 & 40 & 38 & 32 & 20 & 42 & \\
\hline " re-med. & 34 & $M$ & $u$ & 20 & 34 & 38 & 38 & 26 & 36 & \\
\hline Crolergy & 26 & $M$ & $u$ & 28 & 34 & 38 & 48 & $2 t$ & 44 & \\
\hline Science ofirchem & 29 & $M$ & u & 44 & 24 & 30 & 36 & 24 & 32 & \\
\hline Business & 23 & $M$ & u & 42 & 30 & 44 & 34 & $2 t$ & 28 & \\
\hline Music & 19 & $M$ & u & 44 & 40 & 38 & $3 t$ & 28 & 50 & \\
\hline Sciences Premed. & 21 & $F$ & u & 36 & 42 & 30 & 30 & 20 & 46 & \\
\hline Geology & 24 & $M$ & u & 36 & 34 & 38 & 34 & 30 & 34 & \\
\hline Engineers & 17 & $M$ & $u$ & 34 & 40 & 34 & 26 & 32 & 36 & \\
\hline ompuder Sci. & 18 & $M$ & $u$ & 30 & 40 & 40 & 38 & 42 & 20 & \\
\hline Business & 19 & F & $u$ & 40 & 28 & 36 & 26 & 38 & 34 & \\
\hline Science the ind & 19 & $M$ & u & 32 & 42 & 40 & 28 & 30 & 26 & \\
\hline Business & 24 & $F$ & $u$ & 38 & 42 & 48 & 50 & 38 & 34 & \\
\hline - & 24 & $F$ & u & 36 & 36 & 32 & 22 & 22 & So & \\
\hline Business & 22 & $M$ & $u$ & 30 & 44 & 40 & 38 & 24 & 44 & \\
\hline Math/feon. & 27 & $M$ & $u$ & 32 & 38 & 30 & 30 & 24 & 42 & \\
\hline Engr. $\left(G_{x}\right)$ & 21 & $M$ & $u$ & 28 & 32 & 28 & 20 & 12 & 46 & \\
\hline Ryclation & 20 & $F$ & u & 42 & 22 & 28 & 38 & 38 & 28 & \\
\hline Forcign lang. & 22 & $F$ & $u$ & 30 & 32 & 46 & 40 & 30 & 32 & \\
\hline Soude'gy & 20 & $F$ & k & 20 & 28 & 42 & 26 & 26 & 28 & \\
\hline Theatre Arts & - & - & $G$ & 42 & 28 & 40 & 46 & 32 & 48 & \\
\hline Ant & 21 & $F$ & $u$ & 28 & 36 & 38 & 36 & 24 & 28 & \\
\hline Dance & 22 & $f$ & $u$ & 34 & 40 & 40 & 36 & 40 & 36 & \\
\hline Dance & 43 & $F$ & - & 32 & 28 & 40 & 42 & 20 & 40 & \\
\hline Danec/Theature & 23 & $F$ & $u$ & 42 & 38 & 40 & 46 & 44 & 32 & \\
\hline Dance & 21 & $F$ & $u$ & 44 & 36 & 44 & 36 & 38 & 30 & \\
\hline Dance & 31 & $M$ & $u$ & 50 & 42 & So & 50 & 28 & 46 & \\
\hline Figctiding & 23 & $M$ & u & 32 & 30 & 46 & 48 & 10 & 42 & \\
\hline
\end{tabular}




\section{AMERICAN}

\section{Students}

\begin{tabular}{|c|c|c|c|c|c|c|c|c|c|c|}
\hline Major & Age & $M / F$ & Glund. & $V$ & $A^{u}$ & $K^{\prime \prime}$ & $T^{a c}$ & $G^{r o u}$ & $I^{n}$ & School \\
\hline frinch/History & 21 & $M$ & $u$ & 38 & 40 & 56 & 4. & 30 & $2 \delta$ & PSU \\
\hline Oruputer Sciena & 34 & $F$ & $G$ & 48 & 22 & 36 & $4:$ & 10 & so & $\prime \prime$ \\
\hline cs & 28 & $F$ & u & 22 & 46 & 38 & zx & 34 & 30 & \\
\hline 4 & 37 & $M$ & $u$ & 22 & 34 & 32 & 46 & 32 & 26. & \\
\hline$"$ & 28 & - & $G$ & 36 & 30 & $3 t$ & 34 & 38 & 40 & \\
\hline$"$ & 29 & $M$ & u & 36 & 35 & 36 & 38 & 36 & 40 & \\
\hline$"$ & 25 & $m$ & $u$ & 24 & 32 & 40 & 38 & 26 & 32 & \\
\hline , & 35 & $M$ & 6 & 44 & 40 & 22 & 46 & 16 & 44 & \\
\hline$\therefore$ & 44 & $F$ & 6 & 42 & 46 & 38 & 8 & 22 & 44 & \\
\hline , & 27 & $M$ & 6 & $3 t$ & 34 & 36 & 44 & 34 & 30 & \\
\hline . & 43 & $F$ & 6 & 38 & 40 & 46 & 38 & 20 & 50 & \\
\hline '. & - & - & - & 40 & 30 & 32 & 40 & 20 & 38 & \\
\hline Erignger. & 31 & $M$ & u & 32 & 32 & 48 & 42 & 26 & 36 & \\
\hline 1. & 39 & $F$ & $u$ & 38 & 36 & 32 & 38 & 32 & 36 & \\
\hline$"$ & 25 & - & $u$ & 24 & 36 & 42 & 50 & 40 & 36 & \\
\hline "1 & 22 & $M$ & $u$ & 32 & 34 & 34 & 34 & 32 & 44 & \\
\hline " & 22 & $r$ & u & 36 & 40 & $4 i$ & 46 & 28 & 42 & \\
\hline Brof Fre-med & 28 & $M$ & $u$ & 38 & 26 & 36 & 46 & 12 & 50 & \\
\hline$\left.B_{x u}\right|^{\text {Pre }-\operatorname{den} t .}$ & 24 & $M$ & u & 44 & 34 & 40 & 36 & 36 & 30 & \\
\hline Bro. & 35 & $F$ & $u$ & 32 & 42 & 40 & $4:$ & 24 & 44 & \\
\hline$"$ & 39 & $F$ & $u$ & 42 & $2 \delta$ & 40 & 40 & 30 & 34 & \\
\hline 11 & 24 & $M$. & $u$ & 30 & 30 & 38 & 32 & 46 & 28 & \\
\hline Pre the That & 30 & $F$ & - & 38 & 48 & 42 & 32 & 38 & 28 & \\
\hline Phy - ther. & 26 & $F$ & - & 46 & 40 & $4 t$ & 32 & 30 & 34 & \\
\hline Planmey & 21 & $F$ & is & 36 & 46 & $4 t$ & 44 & 24 & 40 & \\
\hline$P_{t e}-D_{\text {cind }} / \mathrm{Sci}$. & 30 & $F$ & $u$ & 40 & 36 & 42 & 48 & 24 & 40 & \\
\hline Bio. & 22 & - & $u$ & 42 & 42 & 46 & 48 & 48 & 32 & \\
\hline Pre - Exind & 24 & $M$ & u & 50 & 28 & 48 & $4 x$ & 20 & 40 & \\
\hline Sin.st. & 22 & $M$ & $u$ & 46 & 40 & 36 & 46 & 46 & 48 & \\
\hline- & 29 & $F$ & u & 28 & 34 & $4 c$ & 35 & 46 & 26 & \\
\hline Gen Studies & 46 & $F$ & u & 28 & 36 & 34 & -4 & 14 & 30 & \\
\hline
\end{tabular}


90

AMERCAN Students

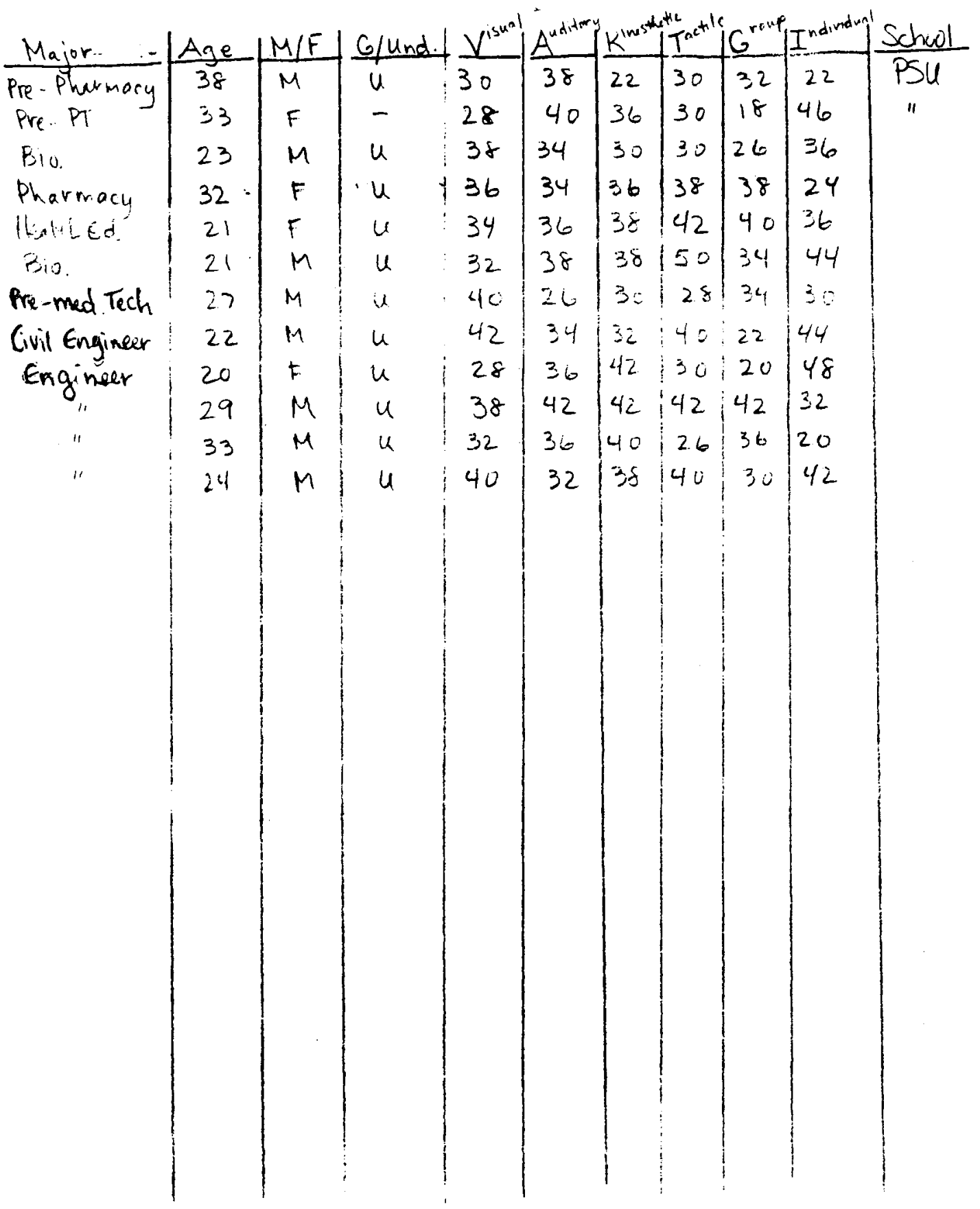


Jrpanese

\section{students (in Japan)}

\begin{tabular}{|c|c|c|c|c|c|c|c|c|c|c|c|}
\hline & Age & $M / F$ & G/und. & 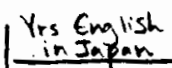 & & $A^{\prime}$ & $L k$ & $T$ & ${ }^{k} G$ & $I^{n}$ & School \\
\hline ch. Engin. & 21 & $\bar{M}$ & $\bar{u}$. & 8 yors & $\overline{20}$ & $\sqrt{42}$ & 40 & $\sqrt{38}$ & 38 & 20 & Daido Irsthtute \\
\hline & 20 & M & u & 8 yors & 32 & 38 & 42 & 46 & 40 & 28 & of Technologu \\
\hline " & 20 & $M$ & u & 8 yrs & 30 & 32 & 38 & 38. & 34 & 28 & 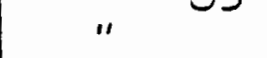 \\
\hline " & 20 & $M$ & u & 7 yrs & 28 & 34 & 44 & 42. & 38 & 32. & \\
\hline . & 22 & $m$ & u & 8 gurs & 32 & 42 & 42 & 38 & $26 \mid$ & 40 & \\
\hline Prchinecture & 21 & M & - & $8 y$ ys & 30 & 38 & $3 t$ & 40. & 34 & 30. & \\
\hline " & 20 & M & u & $9 y+s$ & 32 & 38 & 30 & 30. & $28 \mid$ & 44 & \\
\hline & 20 & M & $u$ & 8 jos & 32 & 44 & 44 & 42 & 50 & 24 & \\
\hline - & 22 & M & - & & 34 & 32 & 38 & 40 & 28 & نu بَ & \\
\hline Appolec Che trowe & 20 & $M$ & u & 8 ys & 32 & 34 & 42 & 42 & 28 & 32 & \\
\hline Electromes & $2 !$ & M & u & gyos & 32 & 34 & 34. & 36 & 20 & 28 & \\
\hline Applike Clext & 21 & M & u & 8 grs & 32 & 36 & 38 & 40 & 40 & 30 & \\
\hline & 21. & M. & $u$ & & 30 & 32 & 38 & 38. & 36 & 34 & \\
\hline- & 20 & M & u & 8 grs & 32 & 42 & 42. & 48 & 28 & 36 & \\
\hline Electrivars & 20 & $M$ & u & 8 yrs & 32 & 34. & 40. & 41 & $3 \delta$ & 26 & \\
\hline Aec Erigin. & 22 & $M$ & u & 9 qus & 40 & 32 & 40 & 40 & 46 & 20 & \\
\hline 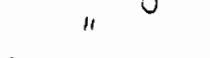 & 20 & m & $u$ & 8 yors & 30 & .38 & 36 & 34 & 50 & 24 & \\
\hline Frecinatesture & 23 & m & - & 10 girs. & 30 & 28 & 38 & 44 & 22 & 30 & \\
\hline " & 20 & $M$ & u & - & 22 & 26 & 34 & 34 & 34 & 24 & \\
\hline " & 22 & m & u & 8 yrs & 34 & 34 & 44. & 40 & 32 & 28 & \\
\hline Engin. & 22 & M & u & & 26 & 38 & 44 & 48 & 44 & 28 & \\
\hline & 21 & M & - & 9 yrs & 34 & 28 & 30 & 34 & 34 & 36 & \\
\hline & 21 & M & u & 9 yrs & 30 & 32 & 34 & 36 & 28 & 22 & \\
\hline int Eng. & 21 & $M$ & u & 8 yos & 20 & 28. & 36. & 40 & 42 & 26 & \\
\hline piples thectrome & 21 & $m$ & u & 10 yos & 28 & 36 & .40 & 38 & 46 & 20 & \\
\hline & 22. & $M$. & $u$ & 10 yis & 36 & 36 & 38 & 44 & 36 & 34. & \\
\hline Legin & 22 & $M$ & u & 10 yors & 32 & 46 & 44 & $4 t$ & 44 & 32 & \\
\hline & 21 & $M$ & $u$ & 9 yors & 28 & 38 & 30 & 40 & 34 & 26 & . \\
\hline " & 23 & $M$ & u & 9 yors & 28 & 36 & 30 & 94 & 38 & 22 & \\
\hline Elec. Engin & 122 & $M$ & u & 9 grs & 24 & 30 & 42 & 42 & 42 & 20 & \\
\hline & & $M$ & $u$ & 8 yors & 20 & 32 & 40 & 36 & 24 & 28 & \\
\hline
\end{tabular}


Japanese

Students (in Japan)

\begin{tabular}{|c|c|c|c|c|c|c|c|c|c|c|}
\hline $1<1$ & 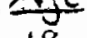 & & & & & & & & & \\
\hline ech. Enginar. & 18 & $M$ & u & $b: 4 r s$ & 30 & 38 & 28 & 26 & 32 & 20 \\
\hline n & 18 & $m$ & $u$ & & 30 & 40 & $E_{2}$ & 34 & 26 & 22 \\
\hline$"$ & 18 & $m$ & 4 & $k$ : & 28 & 32 & 36 & 32 & 32 & 52 \\
\hline . & 18 & $m$ & - & - & 40 & 40 & 38 & 36 & 32 & 30 \\
\hline$"$ & 18 & $M$ & - & $t x \times s$ & 24 & 28 & 36 & 40 & 42 & 18 \\
\hline$"$ & 18 & $M$ & U & 4 & 32 & 40 & 30 & 36 & 30 & 30 \\
\hline$"$ & 18 & $F$ & U & & 30 & 34 & 32 & 32 & 30 & 30 \\
\hline . & 18 & $F$ & U & & 26 & 34 & 34 & 36 & 25 & $\equiv 2$ \\
\hline$\because$ & 19 & $M$ & u & & 28 & 40 & 38 & 34 & 34 & 32 \\
\hline " & 18 & $m$ & $u$ & & 38 & 30 & 30 & 22 & 38 & 26 \\
\hline$\cdot$ & 18 & $M$ & $u$ & & 26 & 42 & 50 & 38 & 50 & 10 \\
\hline$\because$ & 18 & $M$ & - & bigrs & 32 & 44 & 28 & 32 & 34 & 24 \\
\hline. & 18 & $M$ & $u$ & & 22 & 48 & 34 & 26 & 28 & 30 \\
\hline ' & 18 & $M$ & u & & 38 & 30 & 36 & 32 & 32 & 30 \\
\hline$"$ & 18 & $M$ & - & $t:$ & 34 & 32 & $34 \mid$ & 40 & 32 & 34 \\
\hline ' & 18 & $M$ & u & & 32 & 38 & 30 & 30 & 34 & 20 \\
\hline 一 & 19 & $M$ & $u$ & & $2 \delta$ & 38 & 34 & 34 & 32 & 24 \\
\hline Hech Engr. & 18 & $M$ & $u$ & & 30 & 36 & 36 & 38 & 36 & 22 \\
\hline 4 & 18 & $M$ & $u$ & & 30 & 36 & 34 & 34 & 36 & 30 \\
\hline " & 18 & $M$ & u & & 26 & 34 & 38 & 36 & 28 & 24 \\
\hline " & 19 & $M$ & u & & 28 & 40 & 38 & 40 & 32 & 20 \\
\hline " & 18 & $M$ & - & & 24 & 42 & 36 & 38 & $4 t$ & 22 \\
\hline$"$ & 18 & $M$ & U & & 34 & 36 & 38 & 40 & $3 t$ & 32 \\
\hline " & 20 & $M$ & u & beys & 30 & 40 & 144 & 42 & 48 & 30 \\
\hline$"$ & 18 & $M$ & u & $6 y+5$ & 24 & 28 & 140 & 34 & 34 & 22 \\
\hline 一 & 18 & $M$ & u & & 30 & 34 & 30 & 32 & 26 & 26 \\
\hline Mech. Engin. & 19 & $M$ & u & & 30 & 38 & 32 & 34 & 22 & 28 \\
\hline$" 1$ & 18 & $M$ & u & & 22 & 38 & 38 & 40 & 38 & 20 \\
\hline$"$ & 19 & $M$ & U & & 20 & 32 & 38 & 34 & 32 & 30 \\
\hline- & 18 & $M$ & u & & 24 & 30 & $3 t$ & 40 & 34 & 24 \\
\hline eat. Engin. & 18 & $M$ & U & & 10 & 34 & 50 & 50 & 36 & lt \\
\hline
\end{tabular}


JAPANESE

Students (in Japan)

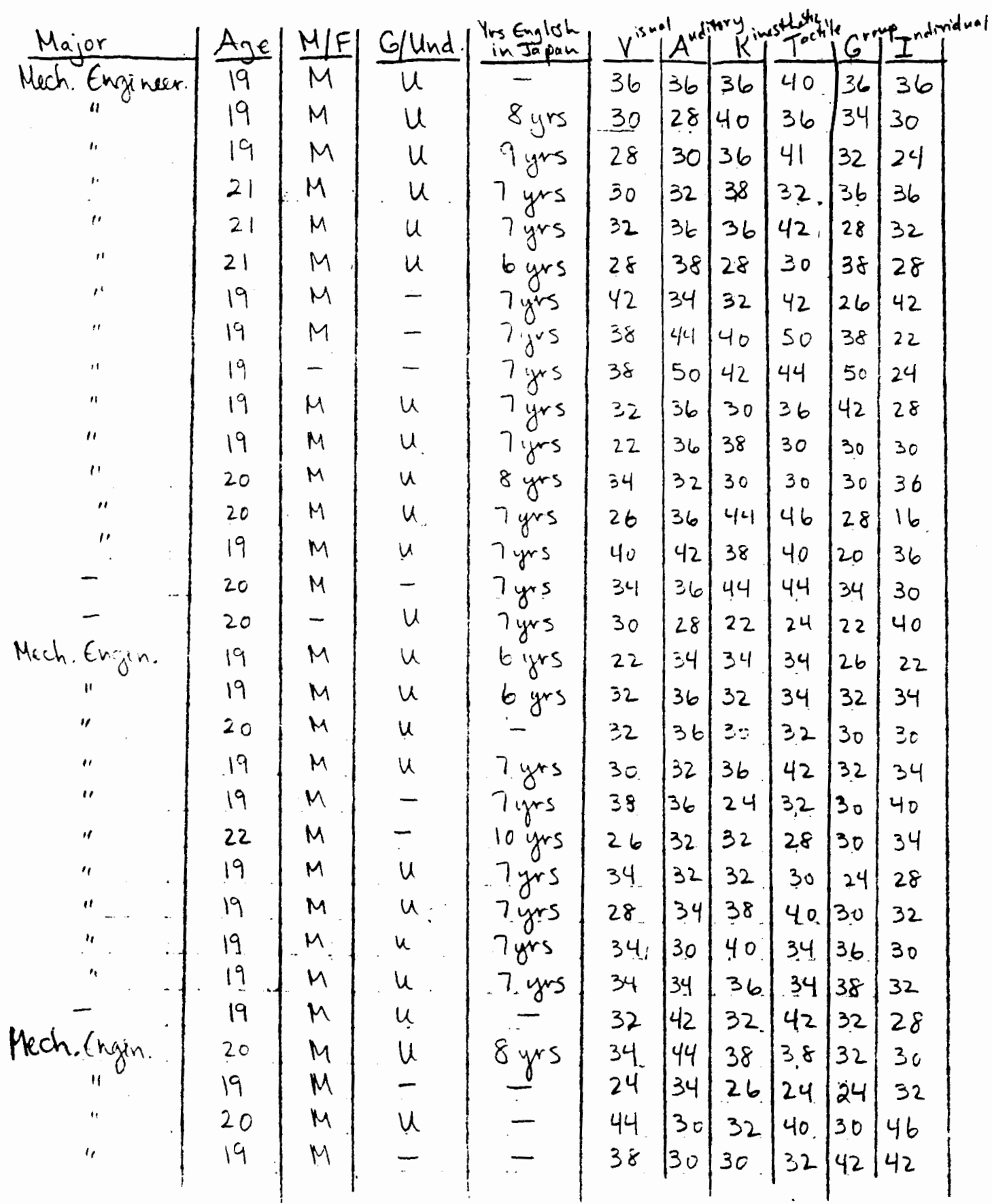




\section{Japanese}

Students (in Iapan)

\begin{tabular}{|c|c|c|c|c|c|c|c|c|c|c|}
\hline Major & Age & $M / F$ & Glund & $\begin{array}{l}\text { Yrs Engles } \\
\text { in Japor }\end{array}$ & $V^{i s v}$ & $\hat{A} A^{\text {udith }}$ & $K^{i n e}$ & thatert & $G^{r e v}$ & $I^{n}$ \\
\hline Mech Engin. & 19 & $M$ & - & 7 ys & 38 & $\overline{38}$ & 40 & 40 & 36 & 30 \\
\hline 1 & 19 & $M$ & - & $7 \cdot 125$ & 34 & 38 & 38 & 40 & 30 & 30 \\
\hline ' & 19 & $M$ & - & & 24 & 42 & 32 & 36 & 32 & 24 \\
\hline$"$ & 20 & $M$ & u & - & 28 & 26 & 18 & 26 & 18 & 28 \\
\hline$"$ & 19 & $M$ & - & 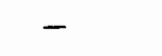 & 36 & $\equiv 6$ & 34 & 34 & 32 & 38 \\
\hline$"$ & 20 & M & u & 7 ins & 32 & 36 & 30 & 40 & 36 & 32 \\
\hline 4 & 19 & $M$ & $u$ & 7 grs & 18 & 36 & 32 & 38 & 32 & 22 \\
\hline " & 19 & $M$ & $u$ & & 24 & 30 & 36 & 42 & 30 & 30 \\
\hline$"$ & 20 & $M$ & - & 6 yos & 30 & 38 & 50 & 48 & 50 & 22 \\
\hline " & 19 & $M$ & $u$ & & 22 & 42 & 42 & 40 & 42 & 20 \\
\hline$"$ & 21 & $M$ & U & $8 y+5$ & 28 & 38 & 40 & 36 & 44 & 18 \\
\hline$"$ & 21 & $M$ & $u$ & 8 irs & 34 & 38 & 36 & 38 & 32 & 32 \\
\hline$"$ & 20 & $M$ & $u$ & & 28 & 40 & 34 & 40 & 24 & 30 \\
\hline " & 19 & $M$ & u & Tuxs & 32 & $3 t$ & 38 & 38 & 38 & 34 \\
\hline$"$ & 19 & $M$ & $u$ & & 28 & 32 & 30 & 36 & 32 & 30 \\
\hline " & 19 & $M$ & - & & 38 & 46 & 44 & 46 & 50 & 28 \\
\hline$" \prime$ & 19 & $M$ & U & & 32 & 40 & 30 & 38 & 50 & 10 \\
\hline$"$ & 19 & $M$ & - & & 40 & 40 & 40 & 38 & 38 & 30 \\
\hline " & 19 & $M$ & u & & 26 & 38 & 36 & 42 & 40 & 24 \\
\hline$"$ & 19 & $M$ & u & & 34 & 36 & 36 & 38 & 34 & 28 \\
\hline ', & 19 & $M$ & $u$ & $7 y+s$ & 24 & 32 & 34 & 30 & 22 & 38 \\
\hline$"$ & 19 & $M$ & $u$ & & 28 & 34 & 34 & 30 & 24 & 34 \\
\hline " & 19 & $M$ & $u$ & & 38 & 34 & 34 & 36 & 22 & 32 \\
\hline " & 20 & $M$ & $u$ & 8 yes & 28 & 36 & 34 & 40 & 26 & 22 \\
\hline 4 & 21 & $M$ & $u$ & & 34 & 28 & 28 & 34 & 20 & 36 \\
\hline$"$ & 19 & $M$ & - & $7 y+s$ & 28 & 34 & 36 & 34 & 32 & 28 \\
\hline$"$ & 19 & $M$ & $u$ & 7 yos & 22 & 30 & 40 & 40 & 36 & 14 \\
\hline " & 19 & $M$ & $u$ & $7 y \times 5$ & 30 & 32 & 34 & 42 & 30 & 34 \\
\hline$"$ & 19 & $M$ & $u$ & 7 yos & 34 & 34 & 34 & 34 & 40 & 20 \\
\hline$"$ & 19 & $m$ & $u$ & 7 yes & 22 & 40 & 38 & 40 & 32 & 18 \\
\hline$"$ & 19 & $M$ & u & 7 irs & 26 & 40 & 38 & 38 & 30 & 30 \\
\hline
\end{tabular}




\section{Japanese}

Students (in Japan)

\begin{tabular}{|c|c|c|c|c|c|c|c|c|c|c|}
\hline Major & Age & $M / F$ & Glund. & $\begin{array}{l}\text { Yrs Crolush } \\
\text { in Jäpoun }\end{array}$ & $\underline{V}^{i s u}$ & $A^{n}$ & $K^{\prime \prime}$ & & 6 & 1 \\
\hline Hech. Engin. & 19 & $M$ & $u$ & & 20 & $\sqrt{46}$ & 40 & $\sqrt{40}$ & $\overline{40}$ & 26 \\
\hline & 19 & $M$ & $u$. & & 24 & 32 & 34 & 40 & 28 & 38 \\
\hline " & 17 & $M$ & u & & 22 & 22 & 12 & 22 & 30 & 24 \\
\hline$"$ & 20 & $M$ & $u$ & & 32 & 32 & 38 & 48 & 30 & 34 \\
\hline " & 21 & $M$ & $u$ & & 34 & 30 & 34 & 36 & 24 & $32^{\prime}$ \\
\hline ". & 19 & $M$ & $u$ & & 36 & 50 & 20 & 34 & 26 & 38 \\
\hline$"$ & 19 & $M$ & u & 7 prs & 34 & 34 & 36 & 34 & 36 & 34 \\
\hline . & 19 & $M$ & $u$ & & 28 & 26 & $\exists \dot{c}$ & 40 & $\therefore t$ & 30 \\
\hline & 19 & $M$ & u & & 28 & 32 & 38 & 30 & 32 & 32 \\
\hline . & 19 & $M$ & u & & 30 & 32 & 34 & 28 & 30 & 24 \\
\hline - & 19 & $M$ & u & & 26 & 30 & 28 & 30 & 24 & 26 \\
\hline Hech Engin. & 19 & $M$ & $u$ & & 34 & 42 & 40 & 48 & 42 & 34 \\
\hline-0 & 20 & $M$ & u & & 28 & 46 & 38 & 40 & 30 & 34 \\
\hline Mach Eve & 19 & $M$ & u & $\delta \lambda^{25}$ & 18 & 28 & 38 & 44 & 38 & 30 \\
\hline 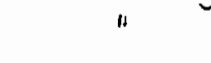 & 19 & $M$ & U & $7: x^{25}$ & 38 & $3 t$ & 32 & 40 & 12 & 50 \\
\hline . & 19 & $M$ & - & & 40 & 38 & 34 & 36 & 40 & 22 \\
\hline " & 19 & $M$ & $u$ & & 26 & 40 & 44 & 46 & 50 & 28 \\
\hline$"$ & 19 & in & u & $8: r^{2}$ & 28 & 32 & 38 & 36 & 30 & 28 \\
\hline y & 19 & $M$ & u & & 32 & 40 & 40 & 40 & 32 & 26 \\
\hline - & 19 & $M$ & $u$ & 7 ines & 24 & 34 & 32 & 36 & 42 & 20 \\
\hline " & 19 & $m$ & $u$ & & 32 & 34 & 32 & $\equiv t$ & 38 & 34 \\
\hline$\therefore$ & 20 & $M$ & - & 10 yos & 30 & 40 & 32 & 36 & 28 & 38 \\
\hline 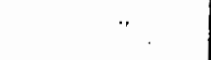 & 19. & $M$ & u & & 44 & 34 & 32 & 30 & 40 & 22 \\
\hline$"$ & 19 & $M$ & u & & 22 & 32 & 24 & 32 & 46 & 24 \\
\hline " & 19 & $M$ & - & $7 y=5$ & 30 & 32 & 32 & 38 & 32 & 30 \\
\hline$\therefore$ & 19 & $M$ & U & & 24 & 26 & 28 & 24 & 24 & 32 \\
\hline “. & 19 & $M$ & U & & 24 & 30 & 32 & 30 & 36 & 26 \\
\hline$\because$ & 19. & $M$ & $u$ & & 34 & 32 & 36 & 36 & 24 & 24 \\
\hline$\therefore$ & 19 & $M$ & $u$ & 7 ges & 28 & 34 & 26 & 36 & 26 & 34 \\
\hline " & 20 & $M$ & u & 8 ivs & 28 & 38 & 34 & 30 & $\equiv 0$ & 32 \\
\hline . & 19 & $M$ & $u$ & $7 n$ & 20 & $j \overline{8}$ & 40 & 38 & 48 & 14 \\
\hline
\end{tabular}


Japanese

Students (in Japan)

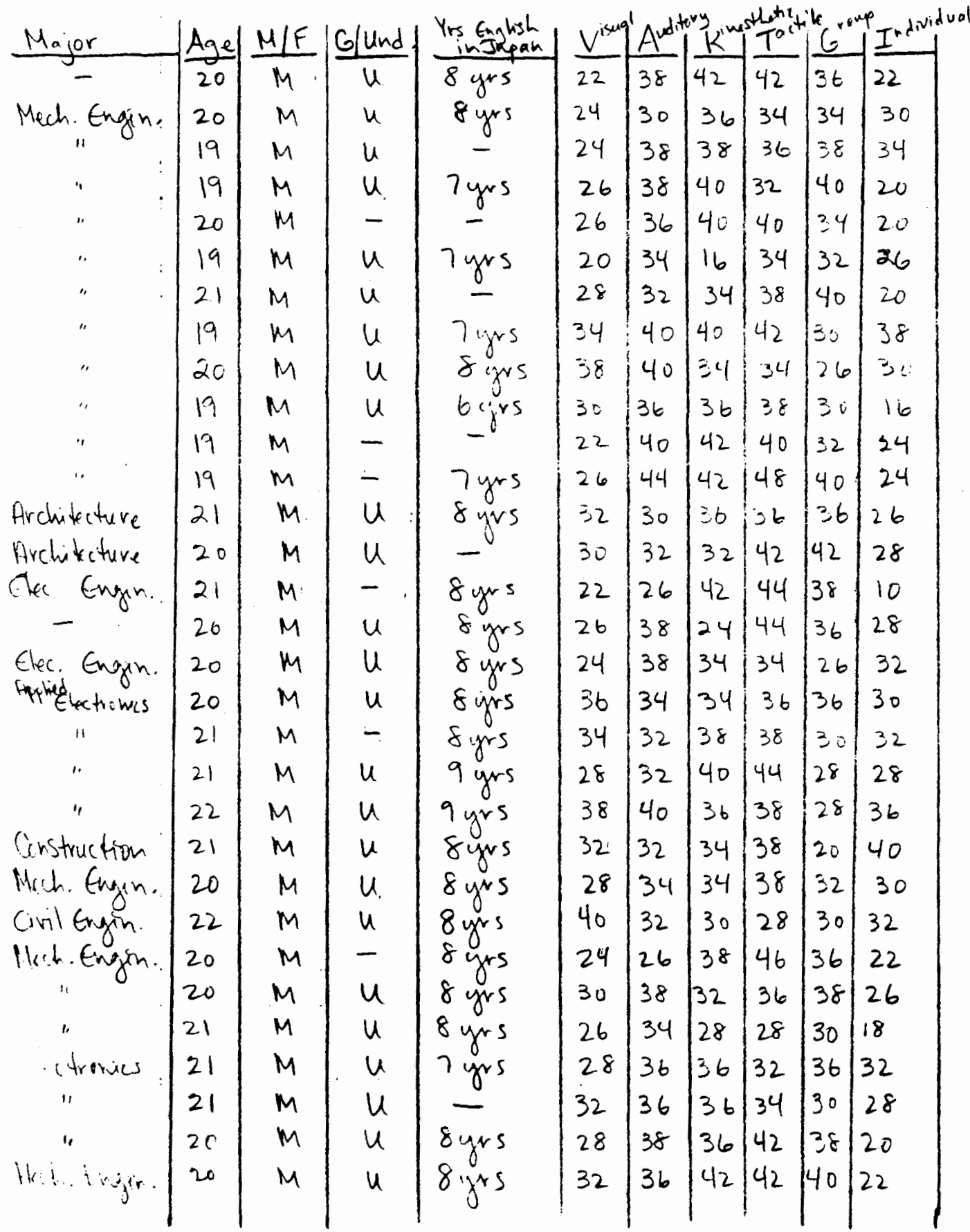




\section{Japanese}

Students (in Japan)

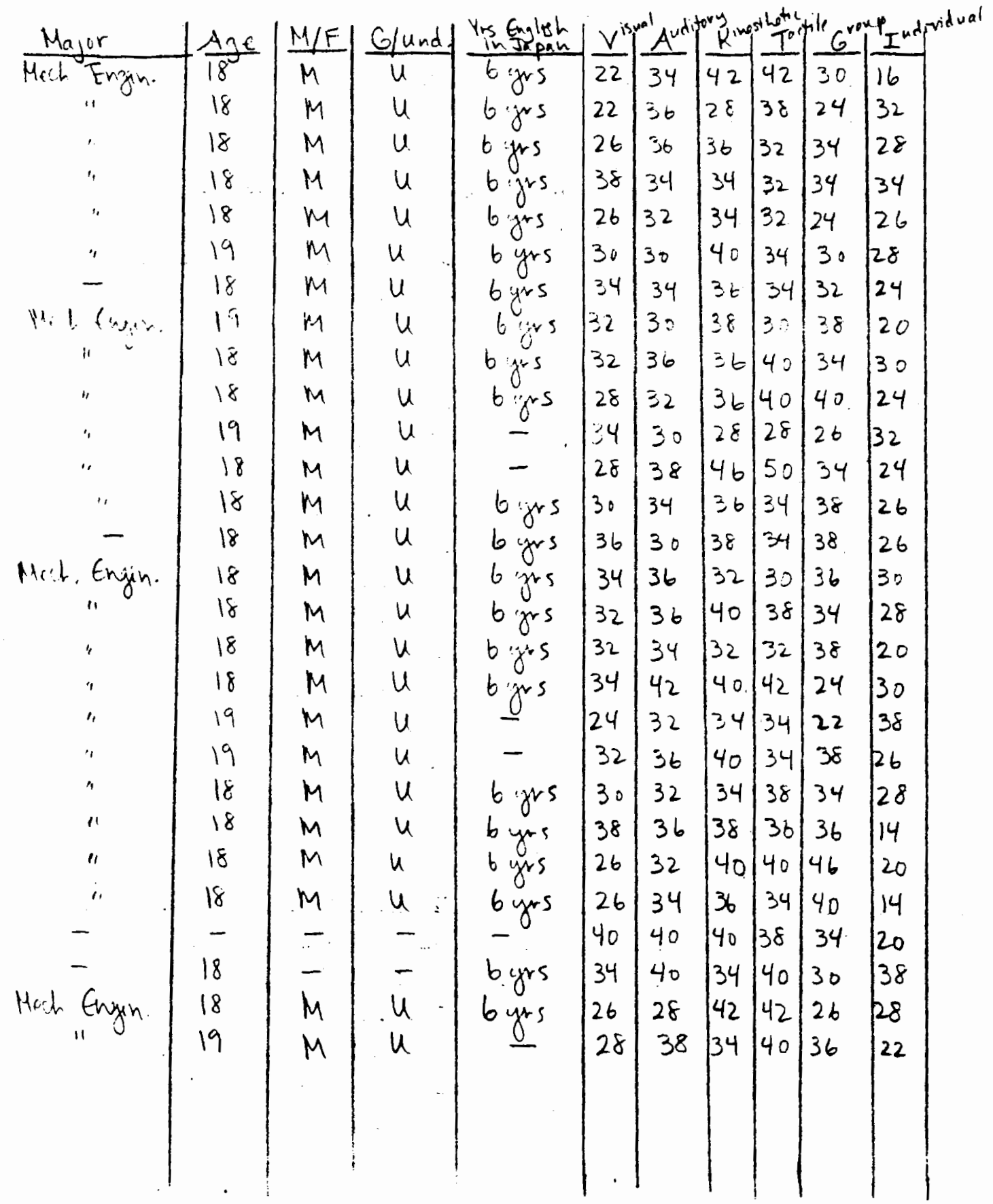




\section{Japanese}

Students (in Iapan)

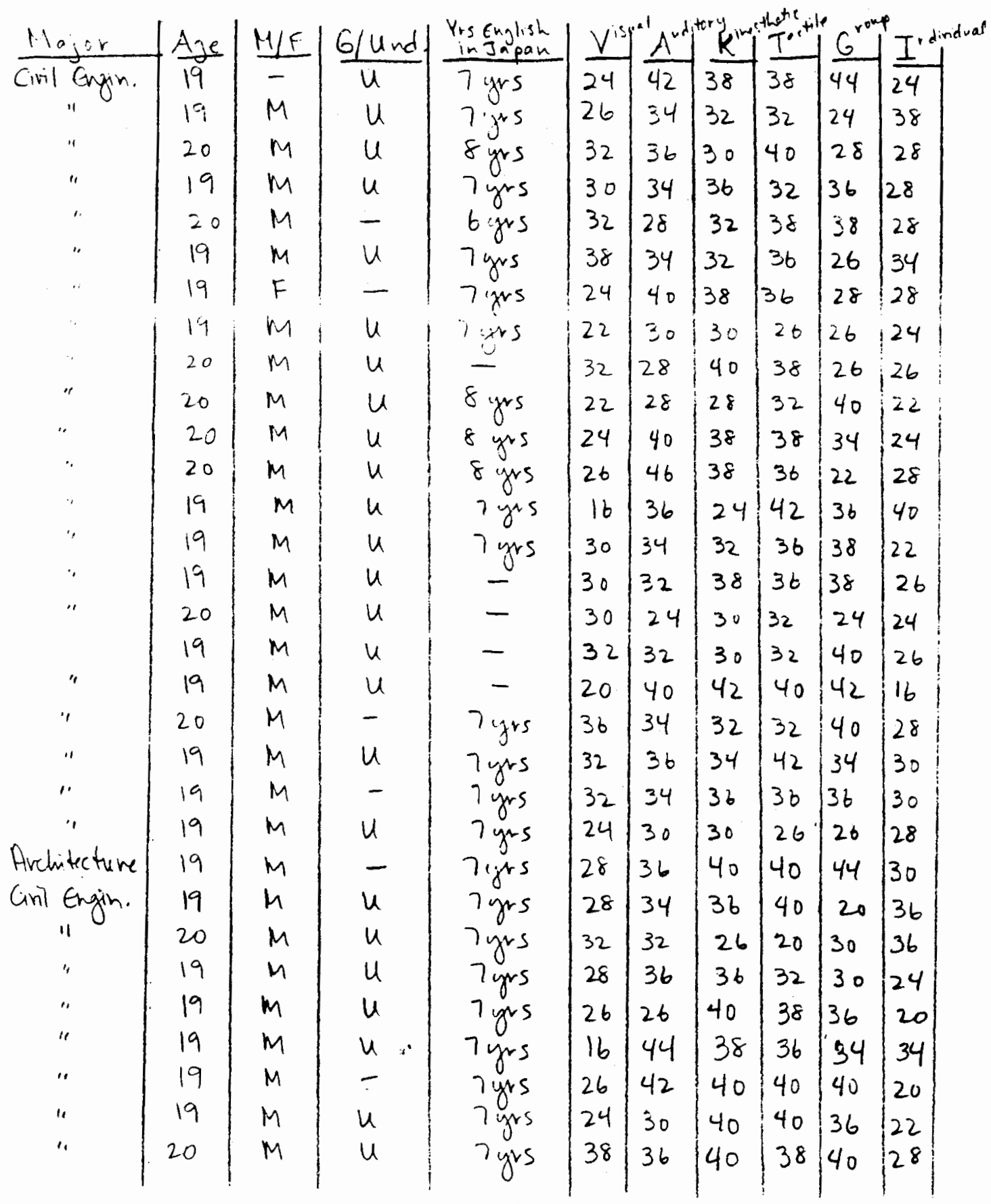




\section{Japanese}

\section{Students (in Irapan)}

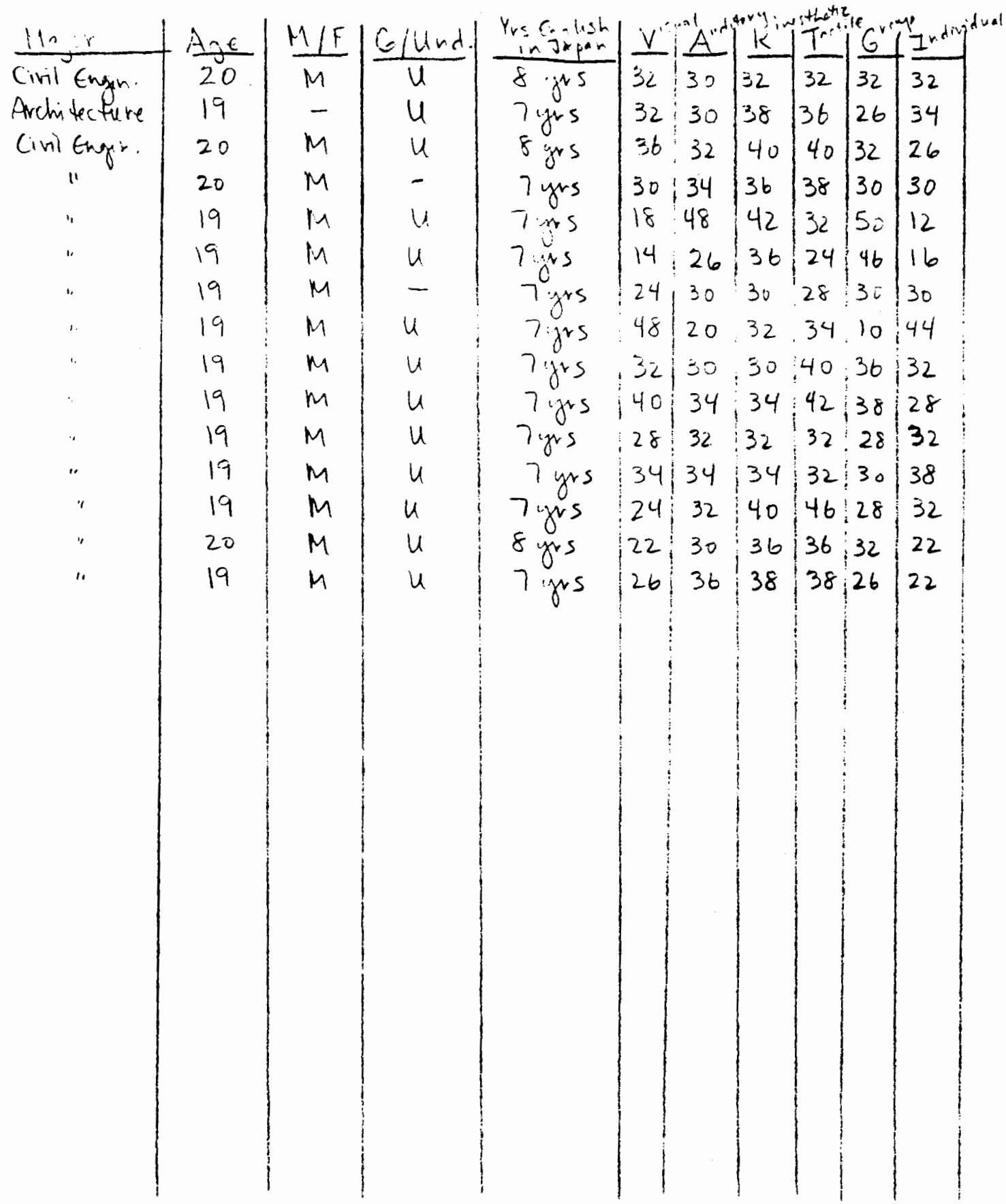




\title{
APPENDIX F
}

\author{
ANOVA'S
}


ANOVA FOR THE JAPANESE IN THE US, JAPANESE IN JAPAN, AND AMERICAN GROUPS

\begin{tabular}{|c|c|c|c|c|c|}
\hline VISUAL & $n=416$ & & & & \\
\hline $\begin{array}{l}\text { Source } \\
\text { students } \\
\text { error }\end{array}$ & $\begin{array}{l}\text { Sum of Square } \\
2764.8 \\
14286.11\end{array}$ & $\begin{array}{l}\frac{D F}{2} \\
413\end{array}$ & $\begin{array}{l}\text { Mean Square } \\
1382.4 \\
34.59\end{array}$ & $\frac{\text { F-Ratio }}{39.96}$ & $\frac{P}{.0001 *}$ \\
\hline AUDITORY & $n=416$ & & & & \\
\hline $\begin{array}{l}\text { Seurce } \\
\text { students } \\
\text { error }\end{array}$ & $\begin{array}{l}\text { Sum of Square } \\
66.22 \\
10736.33\end{array}$ & $\begin{array}{l}\frac{D F}{2} \\
413\end{array}$ & $\begin{array}{l}\text { Mean Square } \\
33.11 \\
26\end{array}$ & $\frac{\text { E-Ratio }}{1.27}$ & $\begin{array}{l}\mathrm{P} \\
.2809\end{array}$ \\
\hline KINESTHETIC & $n=416$ & & & & \\
\hline $\begin{array}{l}\text { Source } \\
\text { students } \\
\text { error }\end{array}$ & $\begin{array}{l}\text { Sum of Square } \\
332.08 \\
12962.03\end{array}$ & $\begin{array}{l}\frac{D F}{2} \\
413\end{array}$ & $\begin{array}{l}\text { Mean Square } \\
166.04 \\
31.39\end{array}$ & $\frac{\text { F-Ratio }}{5.29}$ & $\begin{array}{l}\mathrm{P} \\
.0054 *\end{array}$ \\
\hline TACTILE & $n=416$ & & & & \\
\hline $\begin{array}{l}\text { Source } \\
\text { students } \\
\text { error }\end{array}$ & $\begin{array}{l}\text { Sum of Square } \\
232.91 \\
14593.55\end{array}$ & $\begin{array}{l}\frac{D F}{2} \\
413\end{array}$ & $\begin{array}{l}\text { Mean Square } \\
116.46 \\
35.34\end{array}$ & $\frac{\text { E-Ratio }}{3.3}$ & $\begin{array}{l}\mathrm{P} \\
.038^{*}\end{array}$ \\
\hline GROUP & $n=416$ & & & & \\
\hline $\begin{array}{l}\text { Source } \\
\text { students } \\
\text { error }\end{array}$ & $\begin{array}{l}\text { Sum of Square } \\
1821.31 \\
24894.88\end{array}$ & $\begin{array}{l}\frac{D F}{2} \\
413\end{array}$ & $\begin{array}{l}\text { Mean Square } \\
910.65 \\
60.28\end{array}$ & $\frac{\text { F-Ratio }}{15.11}$ & $\begin{array}{l}\mathrm{P} \\
.0001 *\end{array}$ \\
\hline INDIVIDUAL & $n=416$ & & & & \\
\hline $\begin{array}{l}\text { Source } \\
\text { students } \\
\text { error }\end{array}$ & $\begin{array}{l}\text { Sum of Square } \\
5766.24 \\
20725.76\end{array}$ & $\begin{array}{l}\frac{D F}{2} \\
413 \\
\end{array}$ & $\begin{array}{l}\text { Mean Square } \\
2883.12 \\
50.18\end{array}$ & $\frac{\text { F-Ratio }}{57.45}$ & $\begin{array}{l}\mathrm{P} \\
.0001 *\end{array}$ \\
\hline
\end{tabular}




\section{ANOVA FOR THE AMERICAN STUDENTS AND JAPANESE STUDENTS}

\begin{tabular}{|c|c|c|c|c|c|}
\hline VISUAL & $n=416$ & & & & \\
\hline $\begin{array}{l}\text { Source } \\
\text { students } \\
\text { error }\end{array}$ & $\begin{array}{l}\text { Sum of Square } \\
2735.49 \\
14315.42\end{array}$ & $\begin{array}{l}\frac{D F}{1} \\
414\end{array}$ & $\begin{array}{l}\text { Mean Square } \\
2735.49 \\
34.58\end{array}$ & $\frac{\text { F-Ratio }}{79.11}$ & $\begin{array}{l}\mathrm{P} \\
.0001 *\end{array}$ \\
\hline AUDITORY & $n=416$ & & & & \\
\hline $\begin{array}{l}\text { Source } \\
\text { students } \\
\text { error }\end{array}$ & $\begin{array}{l}\text { Sum of Square } \\
64.48 \\
10738.07\end{array}$ & $\begin{array}{l}\frac{D F}{1} \\
414\end{array}$ & $\begin{array}{l}\text { Mean Square } \\
64.48 \\
25.94\end{array}$ & $\frac{\text { F-Ratio }}{2.49}$ & $\begin{array}{l}\mathrm{P} \\
.1156\end{array}$ \\
\hline KINESTHETIC & $n=416$ & & & & \\
\hline $\begin{array}{l}\text { Source } \\
\text { students } \\
\text { error }\end{array}$ & $\begin{array}{l}\text { Sum of Square } \\
306.33 \\
12987.79\end{array}$ & $\begin{array}{l}\frac{D F}{1} \\
414\end{array}$ & $\begin{array}{l}\text { Mean Square } \\
306.33 \\
31.37\end{array}$ & $\frac{\text { E-Ratio }}{9.76}$ & $\begin{array}{l}\mathrm{P} \\
.0019 *\end{array}$ \\
\hline TACTILE & $n=416$ & & & & \\
\hline $\begin{array}{l}\text { Source } \\
\text { students } \\
\text { error }\end{array}$ & $\begin{array}{l}\text { Sum of Square } \\
45.25 \\
14781.21\end{array}$ & $\begin{array}{l}\frac{D F}{1} \\
414\end{array}$ & $\begin{array}{l}\text { Mean Square } \\
45.25 \\
35.7\end{array}$ & $\frac{\text { F-Ratio }}{1.27}$ & $\frac{P}{.2609}$ \\
\hline GROUP & $\mathrm{n}=416$ & & & & \\
\hline $\begin{array}{l}\text { Source } \\
\text { students } \\
\text { error }\end{array}$ & $\begin{array}{l}\text { Sum of Square } \\
1721.21 \\
24994.98\end{array}$ & $\begin{array}{l}\frac{D F}{1} \\
414\end{array}$ & $\begin{array}{l}\text { Mean_Square } \\
1721.21 \\
60.37\end{array}$ & $\frac{\text { F-Ratio }}{28.51}$ & $\begin{array}{l}\mathrm{P} \\
.0001 *\end{array}$ \\
\hline INDIVIDUAL & $n=416$ & & & & \\
\hline $\begin{array}{l}\text { Source } \\
\text { students } \\
\text { error }\end{array}$ & $\begin{array}{l}\text { Sum of Square } \\
5353.35 \\
21138.65 \\
\end{array}$ & $\begin{array}{l}\frac{D F}{1} \\
414 \\
\end{array}$ & $\begin{array}{l}\text { Mean Square } \\
5353.35 \\
51.06\end{array}$ & $\frac{\text { F-Ratio }}{104.85}$ & $\begin{array}{l}\mathrm{P} \\
.0001 *\end{array}$ \\
\hline
\end{tabular}




\begin{tabular}{|c|c|c|c|c|c|}
\hline VISUAL & $\mathrm{n}=51$ & & & & \\
\hline $\begin{array}{l}\text { Source } \\
\text { students } \\
\text { error }\end{array}$ & $\begin{array}{l}\text { Sum of Square } \\
108.37 \\
1382.61\end{array}$ & $\begin{array}{l}\frac{D F}{1} \\
49\end{array}$ & $\begin{array}{l}\text { Mean Square } \\
108.37 \\
28.22\end{array}$ & $\frac{\text { F-Ratio }}{3.84}$ & $\begin{array}{l}\mathrm{P} \\
.0557\end{array}$ \\
\hline AUDITORY & $n=51$ & & & & \\
\hline $\begin{array}{l}\text { Source } \\
\text { students } \\
\text { error }\end{array}$ & $\begin{array}{l}\text { Sum of Square } \\
9.48 \\
1237.1\end{array}$ & $\begin{array}{l}\frac{D F}{1} \\
49\end{array}$ & $\begin{array}{l}\text { Mean Square } \\
9.48 \\
25.25\end{array}$ & $\frac{\text { E-Ratio }}{.38}$ & $\begin{array}{l}\mathrm{P} \\
.5428\end{array}$ \\
\hline KINESTHETIC & $n=51$ & & & & \\
\hline $\begin{array}{l}\text { Source } \\
\text { students } \\
\text { error }\end{array}$ & $\begin{array}{l}\text { Sum of Square } \\
7.35 \\
2329.28\end{array}$ & $\begin{array}{l}\frac{D F}{1} \\
49\end{array}$ & $\begin{array}{l}\text { Mean Square } \\
7.35 \\
47.54\end{array}$ & $\begin{array}{l}\text { E-Ratie } \\
.15\end{array}$ & $\begin{array}{l}\mathrm{P} \\
.6958\end{array}$ \\
\hline TACTLLE & $\mathrm{n}=51$ & & & & \\
\hline $\begin{array}{l}\text { Source } \\
\text { students } \\
\text { error }\end{array}$ & $\begin{array}{l}\text { Sum of Square } \\
51.31 \\
1755.28\end{array}$ & $\begin{array}{l}\frac{\mathrm{DF}}{1} \\
49\end{array}$ & $\begin{array}{l}\text { Mean Square } \\
51.31 \\
35.82\end{array}$ & $\frac{\text { E-Ratio }}{1.43}$ & $\begin{array}{l}\mathrm{P} \\
.2371\end{array}$ \\
\hline GROUP & $\mathrm{n}=51$ & & & & \\
\hline $\begin{array}{l}\text { Source } \\
\text { students } \\
\text { error }\end{array}$ & $\begin{array}{l}\text { Sum of Square } \\
7.72 \\
2928.44\end{array}$ & $\begin{array}{l}\frac{D F}{1} \\
49\end{array}$ & $\begin{array}{l}\frac{\text { Mean Square }}{7.72} \\
59.76\end{array}$ & $\frac{\text { F-Ratio }}{.13}$ & $\begin{array}{l}\mathrm{P} \\
.7209\end{array}$ \\
\hline INDIVIDUAL & $n=51$ & & & & \\
\hline $\begin{array}{l}\text { Source } \\
\text { students } \\
\text { error }\end{array}$ & $\begin{array}{l}\text { Sum of Square } \\
14.56 \\
2948.42\end{array}$ & $\begin{array}{l}\frac{D F}{1} \\
49\end{array}$ & $\begin{array}{l}\text { Mean_Square } \\
14.56 \\
60.17\end{array}$ & $\frac{\text { F-Ratio }}{.24}$ & $\begin{array}{l}\mathrm{P} \\
.625\end{array}$ \\
\hline
\end{tabular}


ANOVA FOR AMERICAN STUDENTS AND JAPANESE STUDENTS IN THE US LESS THAN AND MORE THAN 3 MONTHS

\begin{tabular}{|c|c|c|c|c|c|}
\hline$\sqrt{\text { VISUAL }}$ & $n=156$ & & & & \\
\hline $\begin{array}{l}\text { Source } \\
\text { students } \\
\text { error }\end{array}$ & $\begin{array}{l}\text { Sum of Square } \\
1040.17 \\
5778.8\end{array}$ & $\begin{array}{l}\frac{\mathrm{DF}}{2} \\
153\end{array}$ & $\begin{array}{l}\text { Mean Square } \\
520.09 \\
37.77\end{array}$ & $\frac{\text { F-Ratio }}{13.77}$ & $\begin{array}{l}\mathrm{P} \\
.0001 *\end{array}$ \\
\hline AUDITORY & $n=156$ & & & & \\
\hline $\begin{array}{l}\text { Source } \\
\text { students } \\
\text { error }\end{array}$ & $\begin{array}{l}\text { Sum of Square } \\
49.16 \\
4629.07\end{array}$ & $\begin{array}{l}\frac{D F}{2} \\
153\end{array}$ & $\begin{array}{l}\text { Mean Square } \\
24.58 \\
30.26\end{array}$ & $\frac{\text { E-Ratio }}{81}$ & $\begin{array}{l}\mathrm{P} \\
.4457\end{array}$ \\
\hline KINESTHETIC & $n=156$ & & & & \\
\hline $\begin{array}{l}\text { Source } \\
\text { students } \\
\text { error }\end{array}$ & $\begin{array}{l}\text { Sum of Square } \\
243.92 \\
5904.67\end{array}$ & $\begin{array}{l}\frac{\mathrm{DF}}{2} \\
153\end{array}$ & $\begin{array}{l}\text { Mean Square } \\
121.96 \\
38.59\end{array}$ & $\frac{\text { E-Ratio }}{3.16}$ & $\begin{array}{l}\mathrm{P} \\
.0452 *\end{array}$ \\
\hline TACTILE & $\mathrm{n}=156$ & & & & \\
\hline $\begin{array}{l}\text { Source } \\
\text { students } \\
\text { error }\end{array}$ & $\begin{array}{l}\text { Sum of Square } \\
268.12 \\
6967.24\end{array}$ & $\begin{array}{l}\mathrm{DF} \\
2 \\
153\end{array}$ & $\begin{array}{l}\text { Mean Square } \\
134.06 \\
45.54\end{array}$ & $\frac{\text { E-Ratio }}{2.94}$ & $\begin{array}{l}\mathrm{R} \\
.0556\end{array}$ \\
\hline GROUP & $n=156$ & & & & \\
\hline $\begin{array}{l}\text { Source } \\
\text { students } \\
\text { error }\end{array}$ & $\begin{array}{l}\text { Sum of Square } \\
404.93 \\
11593.43\end{array}$ & $\begin{array}{l}\frac{D F}{2} \\
153\end{array}$ & $\begin{array}{l}\text { Mean_Square } \\
202.47 \\
75.77\end{array}$ & $\frac{\text { E-Ratio }}{2.67}$ & $\begin{array}{l}\mathrm{P} \\
.0723\end{array}$ \\
\hline INDIVIDUAL & $\mathrm{n}=156$ & & & & \\
\hline $\begin{array}{l}\text { Source } \\
\text { students } \\
\text { error }\end{array}$ & $\begin{array}{l}\text { Sum of Square } \\
1112.92 \\
9177.41\end{array}$ & $\begin{array}{l}\frac{D F}{2} \\
153 \\
\end{array}$ & $\begin{array}{l}\text { Mean Square } \\
556.46 \\
59.98 \\
\end{array}$ & $\frac{\text { F-Ratio }}{9.28}$ & $\begin{array}{l}\mathrm{P} \\
.0002 *\end{array}$ \\
\hline
\end{tabular}

* significant 


\section{ANOVA FOR DIFFERENCES IN GROUP MEAN SCORES BY MAJOR FIELD OF STUDY}

\begin{tabular}{|c|c|c|c|c|c|}
\hline VISUAL & $\mathrm{n}=361$ & & & & \\
\hline $\begin{array}{l}\text { Source } \\
\text { students } \\
\text { error }\end{array}$ & $\begin{array}{l}\text { Sum of Square } \\
2043.26 \\
13598.98\end{array}$ & $\begin{array}{l}\frac{\mathrm{DF}}{4} \\
356\end{array}$ & $\begin{array}{l}\text { Mean Square } \\
510.81 \\
38.2\end{array}$ & $\frac{\text { F-Ratio }}{13.37}$ & $\frac{\mathrm{P}}{.0001 *}$ \\
\hline AUDITORY & $n=361$ & & & & \\
\hline $\begin{array}{l}\text { Source } \\
\text { students } \\
\text { error }\end{array}$ & $\begin{array}{l}\text { Sum of Square } \\
64.18 \\
9341.17\end{array}$ & $\begin{array}{l}\mathrm{DF} \\
4 \\
356\end{array}$ & $\begin{array}{l}\text { Mean Square } \\
16.05 \\
26.24\end{array}$ & $\begin{array}{l}\text { E-Ratio } \\
.61\end{array}$ & $\begin{array}{l}\mathrm{P} \\
.6546\end{array}$ \\
\hline KINESTHETIC & $n=361$ & & & & \\
\hline $\begin{array}{l}\text { Source } \\
\text { students } \\
\text { error }\end{array}$ & $\begin{array}{l}\text { Sum of Square } \\
300.75 \\
10603.8\end{array}$ & $\begin{array}{l}\mathrm{DF} \\
4 \\
356\end{array}$ & $\begin{array}{l}\text { Mean Square } \\
75.19 \\
29.79\end{array}$ & $\frac{\text { F-Ratio }}{2.52}$ & $\frac{P}{.0407 *}$ \\
\hline TACTILE & $\mathrm{n}=361$ & & & & \\
\hline $\begin{array}{l}\text { Source } \\
\text { students } \\
\text { error }\end{array}$ & $\begin{array}{l}\text { Sum of Square } \\
361.55 \\
12300.43\end{array}$ & $\begin{array}{l}\frac{\mathrm{DF}}{4} \\
356\end{array}$ & $\begin{array}{l}\text { Mean Square } \\
90.39 \\
34.55\end{array}$ & $\frac{\text { E-Ratio }}{2.62}$ & $\begin{array}{l}\mathrm{P} \\
.035^{*}\end{array}$ \\
\hline GROUP & $n=361$ & & & & \\
\hline $\begin{array}{l}\text { Source } \\
\text { students } \\
\text { error }\end{array}$ & $\begin{array}{l}\text { Sum of Square } \\
1557.37 \\
22359.01\end{array}$ & $\begin{array}{l}\frac{D F}{4} \\
356\end{array}$ & $\begin{array}{l}\text { Mean Square } \\
389.34 \\
62.81\end{array}$ & $\frac{\text { E-Ratio }}{6.2}$ & $\begin{array}{l}\mathrm{P} \\
.0001 *\end{array}$ \\
\hline INDIVIDUAL & $\mathrm{n}=361$ & & & & \\
\hline $\begin{array}{l}\text { Source } \\
\text { students } \\
\text { error } \\
\end{array}$ & $\begin{array}{l}\text { Sum of Square } \\
3826.59 \\
19219.29\end{array}$ & $\begin{array}{l}\mathrm{DF} \\
4 \\
356 \\
\end{array}$ & $\begin{array}{l}\text { Mean Square } \\
956.65 \\
53.99 \\
\end{array}$ & $\frac{\text { F-Ratio }}{17.72}$ & $\frac{\mathrm{P}}{.0001 *}$ \\
\hline
\end{tabular}

